\title{
علاقة الرؤى والأحلام بالنبوات عند مفكري الإسلام
}

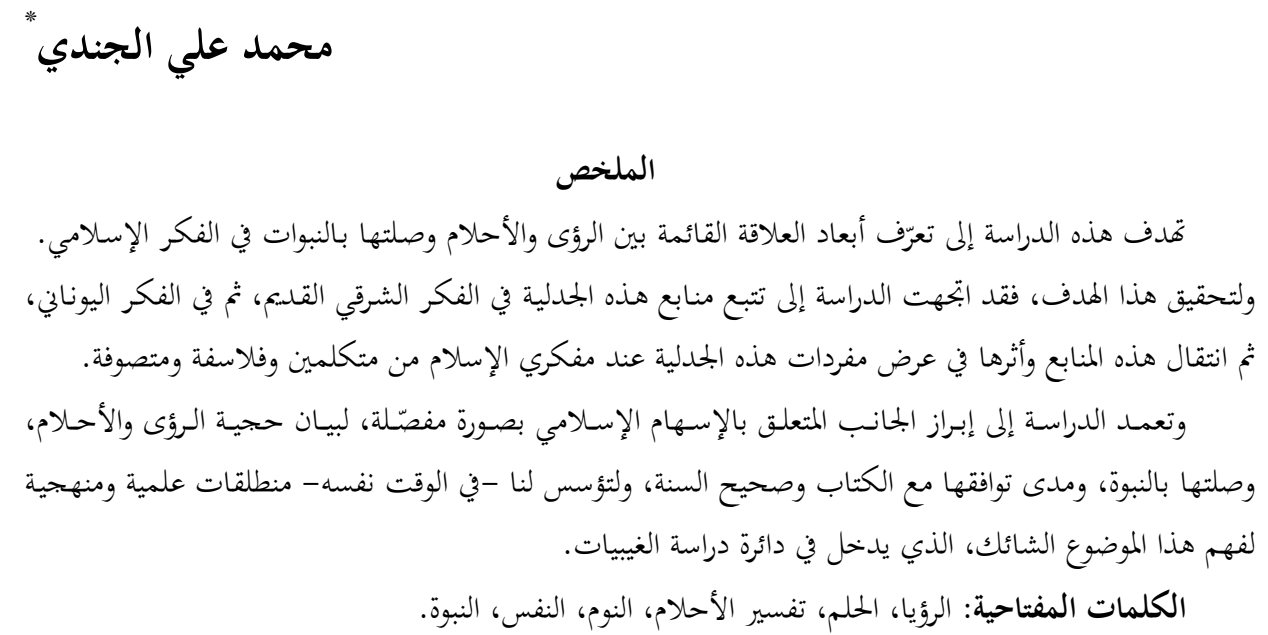

\section{Visions and Dreams and their connection to Prophethood in Islamic Thought}

Abstract

This study aims to explore the connecting dimension, between visions and dreams and their connection to Prophethood in Islamic thought. To achieve this aim, the study had reviewed the sources of the debate on this issue, including the oriental religious thought, Greek thought, and their effects upon Muslim theologians, philosophers and sophists).

The study also discusses Islamic contribution thoroughly to show how visions and dreams were presented in the noble Quran and authentic Sunna of the Prophet, and to lay down a knowledge base and methodology to understand this issue that is part of unseen domain.

Keywords: vision, dream, interpretation of dreams, sleeping, psychic, Prophethood.

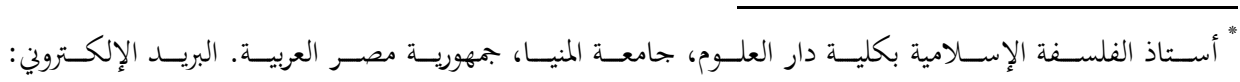

$$
\begin{aligned}
& \text { mohamedelgendy45@yahoo.com }
\end{aligned}
$$

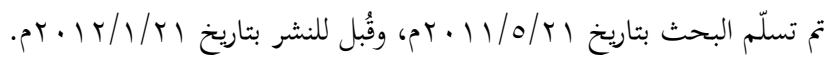




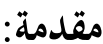

موضـوع الـرؤى والأحسـام حبيـب إلى نفـوس النـاس، مـتى صـادفوا باحثـاً عـرض لدراستها، وثـب إلى خـواطرهم الاستفسـار عـن حقيقتها، والسؤال عـن مـدى صـدقها، وكشفها عن وجوه الغيب، وإذا ماكانت الرؤيا الصادقة وحياً إلهياً أم لا.

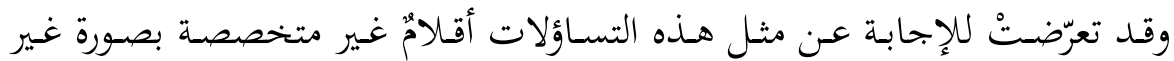
علمية، وبعيدة عن روح الإسلام؛ وذلك بهـف إشباع رغبة القارئ لمثل هذا اللون من الدراسات، التي تركز على رموز تفسير الأحلام، وتأويل الرؤى ومعانيها، ومدى ارعبد ارتباطها

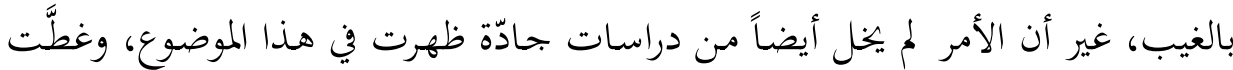
مساحة لا بأس بها من بعض جوانبه المختلفة، خحاصة مـا يتعلق منها بدراسات الدكتور

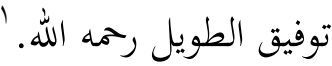

ونظراً إلى ارتبـاط موضـوع الـؤى والأحسلام بـالنبوات في العقيـدة الإسـلامية (القـرآن

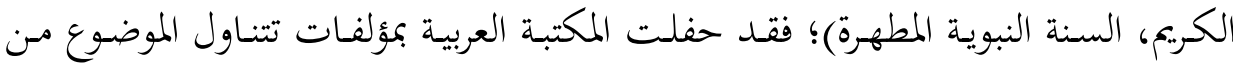
منظور عقدي دراسةً وتحقيقاً، وأصبحت تحتل -دون منازع- الجانب الأكبر من المؤلفات

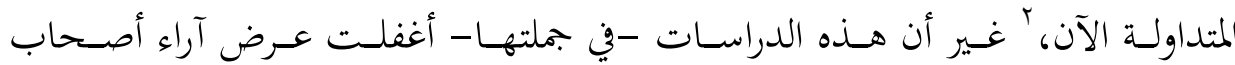
الاتحاهات الأخرى، كالفلاسفة والمتكلمين والمتصوفة بالتفصيل المناسب. هذا بالإضافة إلى مـا ظهر من المؤلفات السيكولوجية المتنوعة التي عالجـت موضوع

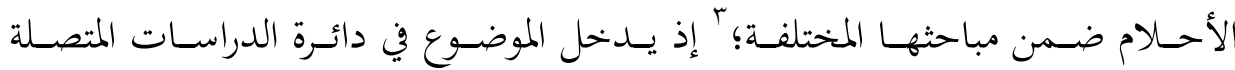
بالتحليل النفسي، ودراسة الجانب اللاشعوري من النفس الإنسانية، على أساس أن الحلم

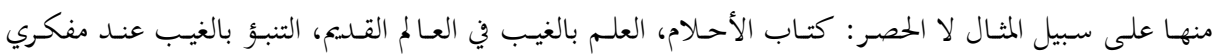
الإسلام. ومن الدراسات الحديثة، الدراسة الأكاديمية الآتية:

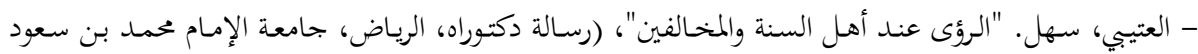

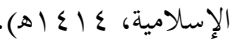
' منها على سبيل التمثيل: كتاب تعبير الرؤيا لابن سيرين، والنامج في تعبير الرؤيا لابن غنام، وغيرها الكثير.

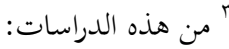

- Frued, Sigmund. Interpration of Dream ,oxford (1923).

- Forester(M). Studies on dreams (1921). 
مـا هو إلا تعبير عن رغبة مكبوتة. وهي مؤلفـات غطت في بابها جانباً لا بأس بـه مـن

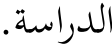

والطابع العام الذي يغلب على دراسة موضوع الرؤى والأحهلام، هو قلة مـاكتب

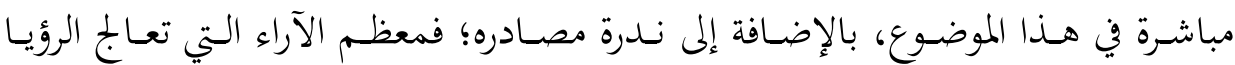

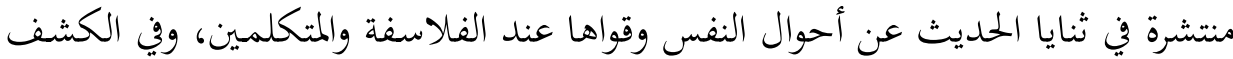
الصوفي والإلمام في المعرفة الذوقية عند الصوفية.

وبكثُّا للموضـوع في جوانبـه المتشعبة في شتى العصور، وعنــ مختلف المفكرين مـن

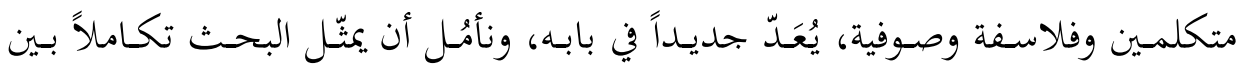
عناصر الموضوع في جانبيه الديني والفلسفي.

\section{أولاً: علاقة الؤَيا والحُحْم (الحُحلم) بالنبوة}

يعرّف بعض الباحثين المنام بأنه بحموع ما يراه أو يبصره النائم من أشياء، أو ما يأتي

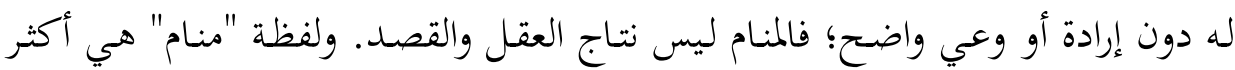

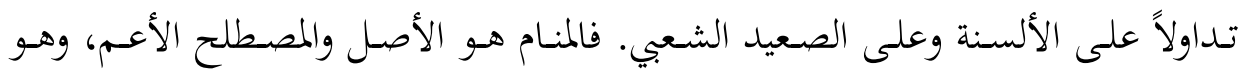
ينقسم إلى رؤيا وحُلم.

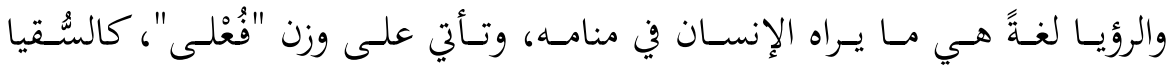

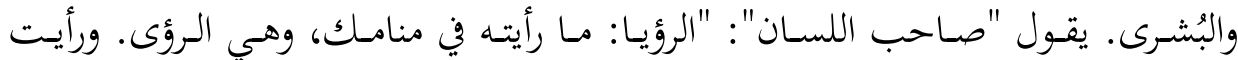

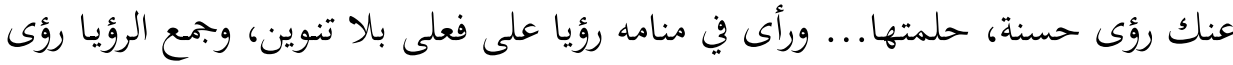

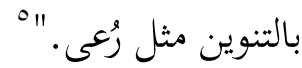

نلاحظ مـن التعريف السابق أن ابن منظور في تعريفه للرؤيا يجعلها مرادفة للحُلمى،

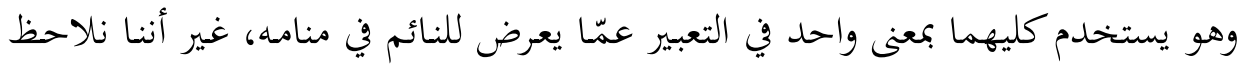

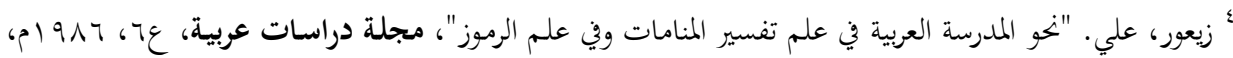

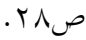

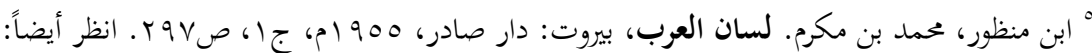

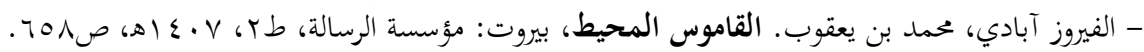


أن هناك فرقاً بين الرؤيا والحلم. فالحُلم: هو ما يراه النائم. قال الجوهري في "الصحاح":

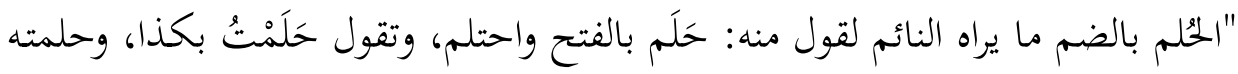

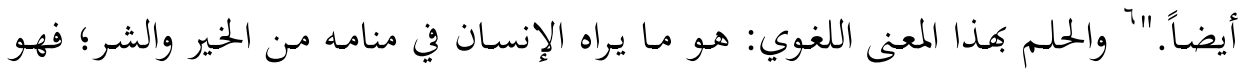

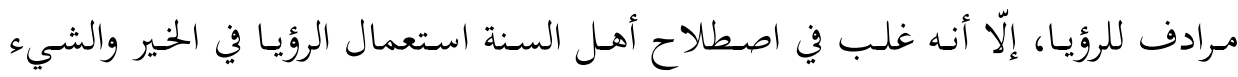

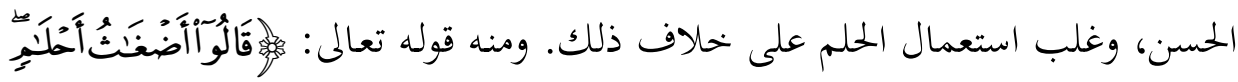

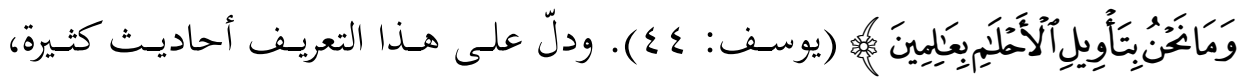

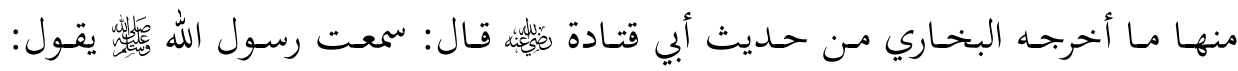

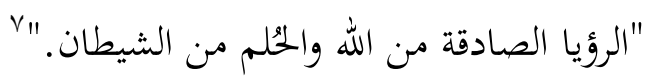

يذهب أهل السُّنة إلى أن الوحي هو الإعلام السريع الخفي؛ إمّا في اليقظة، وإمّا في

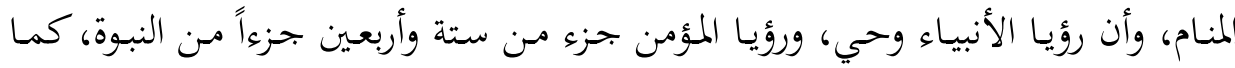

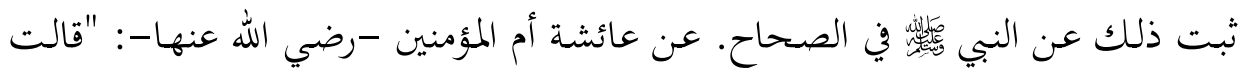

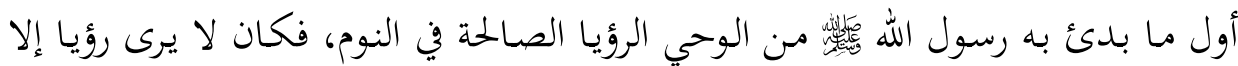

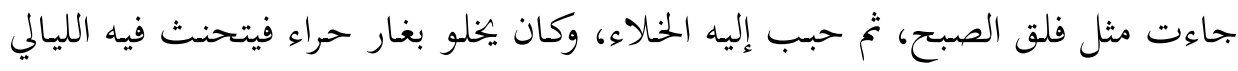

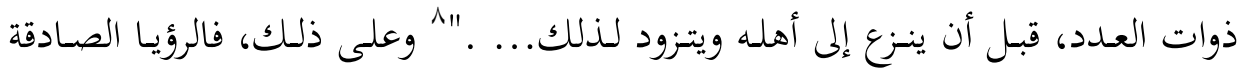

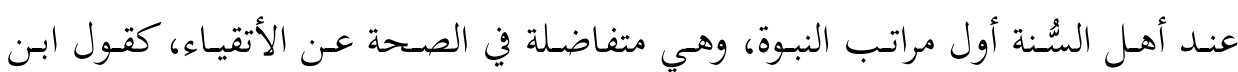

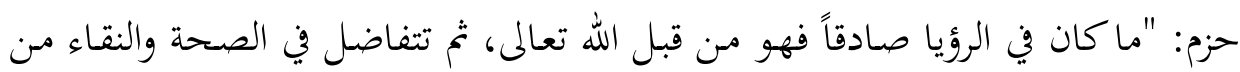

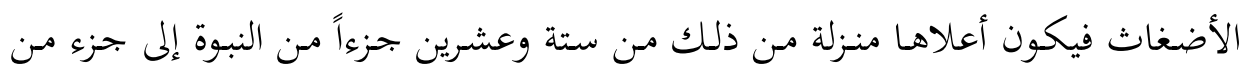

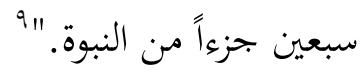

أمّا بالنسبة إلى موقف الفلاسفة مـن الرؤيا فنجـد الكندي في رسالته "النوم والرؤيا"

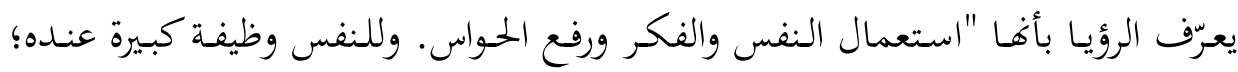

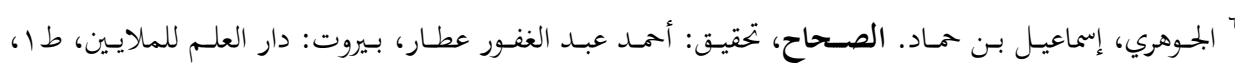

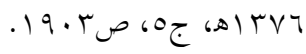

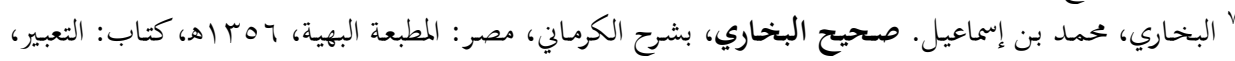

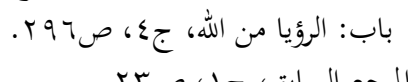

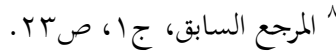

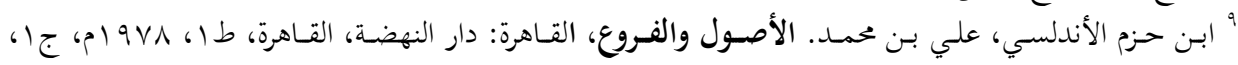


فهي تعرف كل ما في العالم إذا كانت تامة الصقل والنقاء، بحيث تنعكس المعلومات فيها

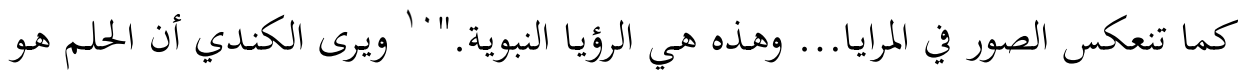

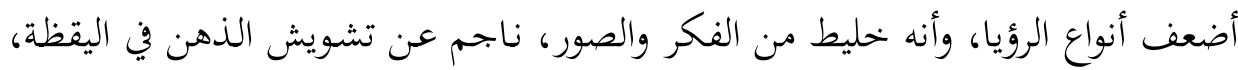
فيحدث له في النوم.

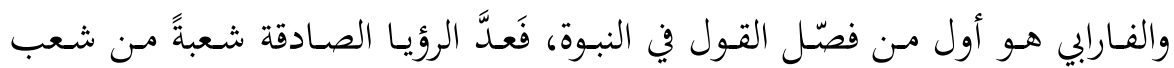

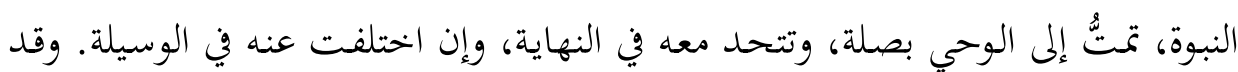

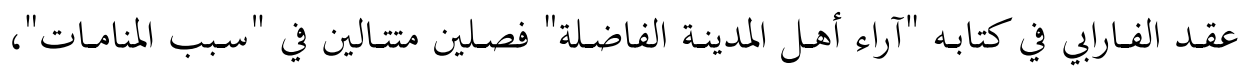

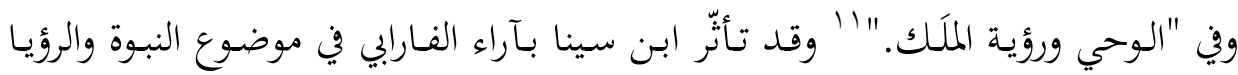

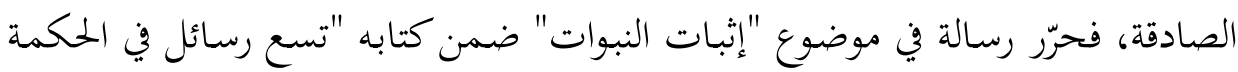

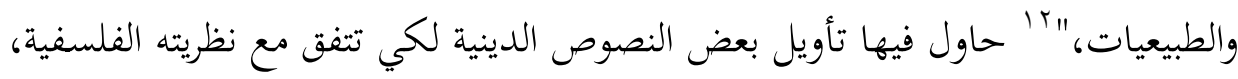
كما سنرى لاحقاً.

أما ابن رشد فقد أعطى الرؤى وصلتها بالنبوة اهتماماً لا بأس به من فلسفته؛ فهو

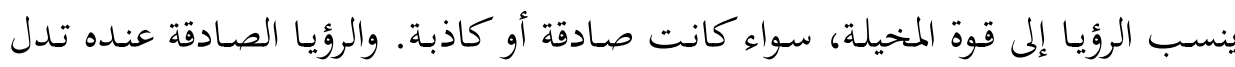

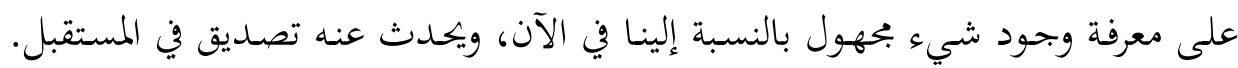

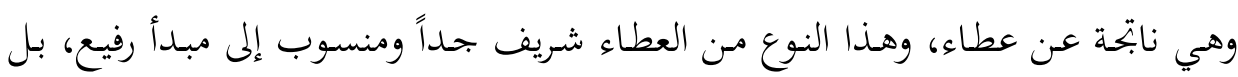

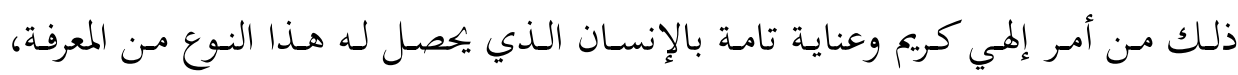
وماهية النبوة داخلة في هذا الفرع من العطاء. وإذا مـا انتقلنـا إلى الصوفية وجددنا أن أتباعها يربطون بين الرؤيا والنبوة، شأفهم في ذلك شأن فلاسفة الإسلام، وإن اختلف المنهج عندهم. فالصوفي يولي الأحلام أهمية •' الكندي، يعقوب بن إسحق. رسائل الكندي الفلسفية، تحقيق: حممد عبد الهادي أبو ريده، القاهرة: دار الفكر

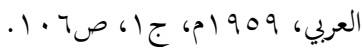

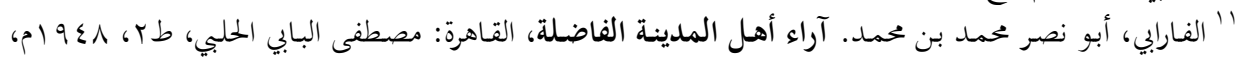

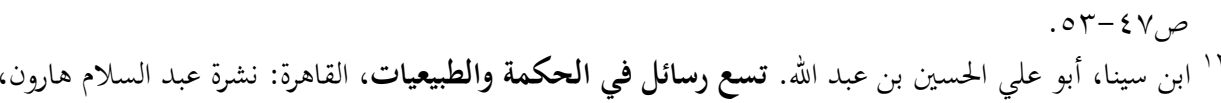

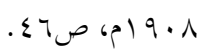

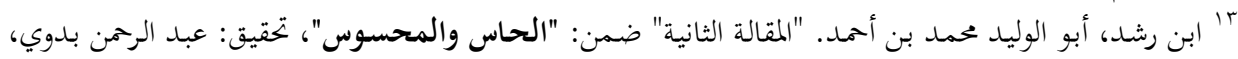

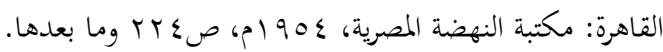


كبيرة، ويرى أها نافذة على الروح، أو هي جسر بينه وبين الغيب. وفيما يخصّ موقفهم مـن النبوة، فقـد ربطوا بينها وبـين الولايـة؛ فبعضهـم جعـل النبوة صسنو الولايـة، وبعضههم الآخـر (الغـلاة) رفعها فـوق مرتبـة النبـوة. أمّا المعتـلون مـنهم فجعلوا الولايـة دون النبوة، على ما سيأتي تفصيله.

\section{ثانياً: أصول دراسة الرؤى والأحلام ومصادرها}

\section{1 الديانات الشرقية القديمة:}

يـذهب بعض مـؤرخي العقائـد والأديـان عُ إلى أنَّ الأحهالام هـي أصـل نشـأة العقيـدة عنــ الإنسـان، فاهتـاء الإنسـان إلى الروح مـدّه الرؤى والأحـلام، واهتـاؤه إلى الإيمـان بوجـود الروح على أي معنى مـن المعاني التي فهمها، فتح أمام عقله نافذة على مـا وراء المحسوس. فهو يرى في منامـه رؤى سعيدة وأحلامـاً مفزعـة، فيستيقظ بعد الرؤيا يبحـث عمـا أسعده فـلا بيجـد شـيئاً، ويصسحو فزعـاً بعـد حلم مـزعج فـلا يـرى مـا رآه في حلمـهـ، ويفكر في ما وراء الحس، أين ذلك الذي جعله يبتهج? وأين ذلك الذي أفزعه؟ وقد يرى

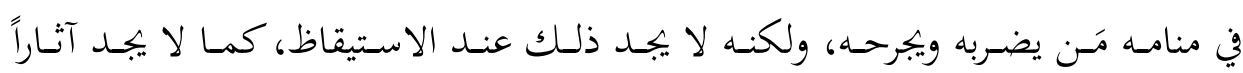
للجروح والضرب، وقد يرى أيضاً ما يبهجه،، ولكن صحوه يضع حداً لما سرّه ولما ساءه وأفزعه.

\section{إذن؛ هناك أشياء بحهولة وراء الحس!}

وبالمثل، فعندما تواجهه مشكلة الموت في المنام، لا يجد لها تفسيراً صحيحاً، وأقصى مـا يصل إليه إدراكه -بعد محاولات عدّة مـن إعمال الفكر والتأمّل - هو أن هنـاك عالماً بحهولاً وراء الحس والمشاهدة، وأن وراء الحس "روحاً" غير الجسد. 17

$$
\text { \&'ا انظر على سبيل المثال لا الحصر: }
$$

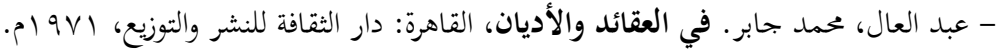

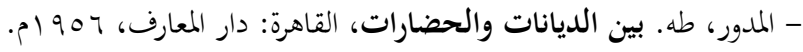

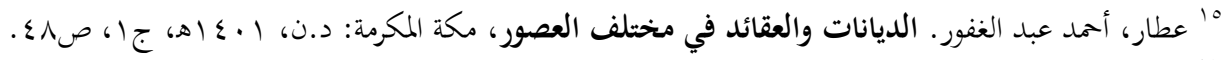

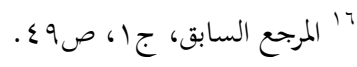


وهذا الإدراك أو الاهتداء إلى فكرة الروح كان أولى الخطوات لانطلاق العقل البشري

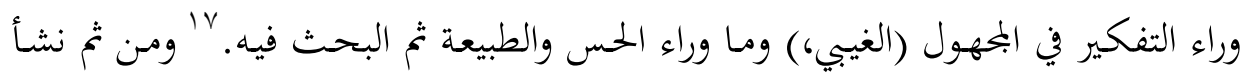

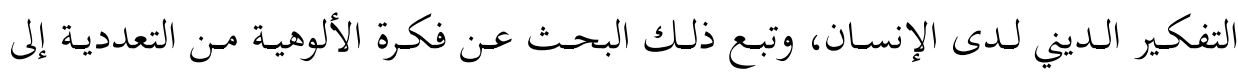
الوحدانية.

\section{أ. ديانة بابل (الكلدان آT ق.م):}

أولت الديانة البابلية الأحلام أهمية كبيرة، فقد شاع عندهم ربط الحلم بالعالم المجهول

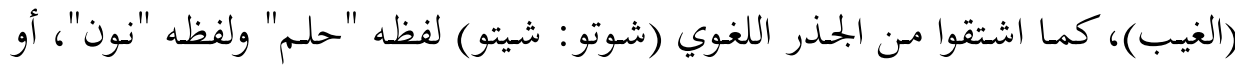

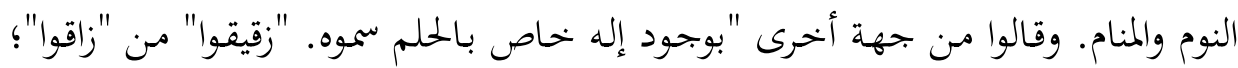

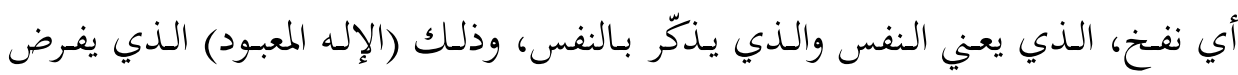

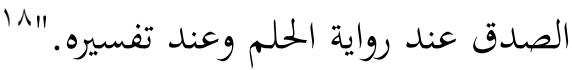

ويوجدد في التراث البابلي أيضاً مفتـاح للأحلام (أي تفسير)؛ "إذ إنَّ إعطاء الحساكم

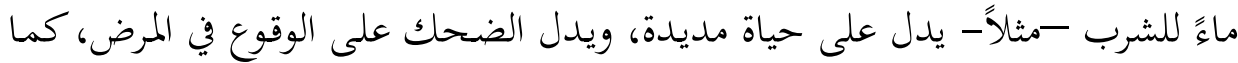

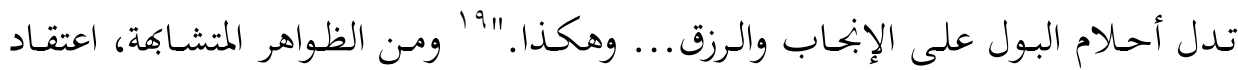

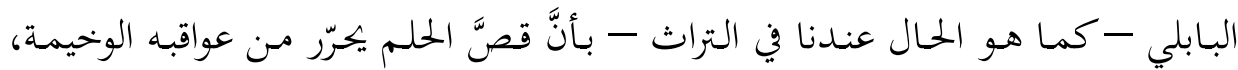
وقد أقام البابليون علاقة بين الحلمم والتنبؤ وجعلوه رسالة إلهية.

$$
\text { ب. الديانة البوذية (•^هـ ق.م): }
$$

أول مـا يصـادفنا في الديانات الشـرقية القديمـة الديانـة البوذيـة التي يؤمن معتنقوهـا،

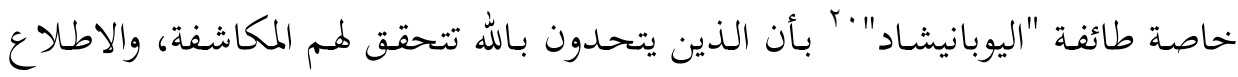

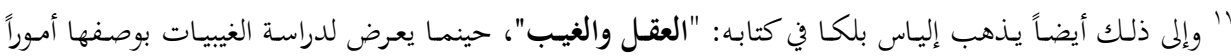

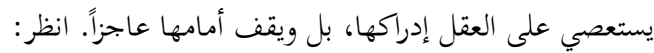

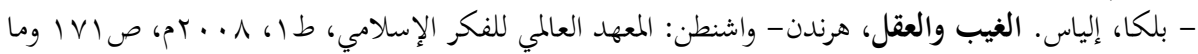

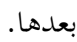

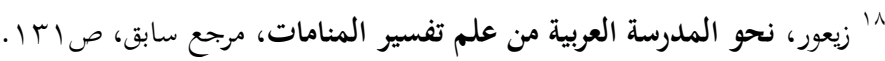

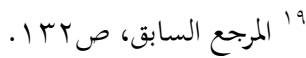

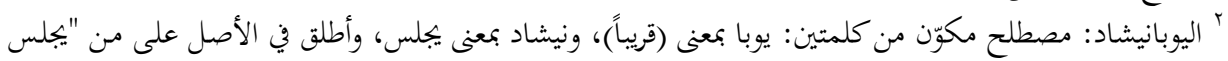

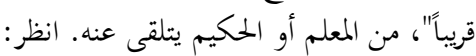


على الغيب، والتنبؤ به، والإفادة منه في تفسير المرائي المختلفة، إبان النوم. أمّا في حال

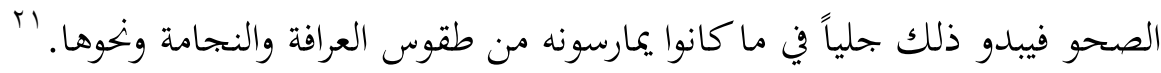

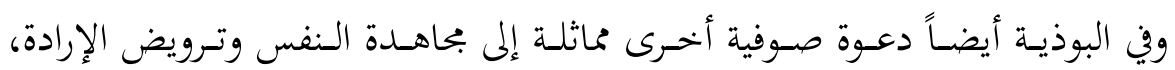

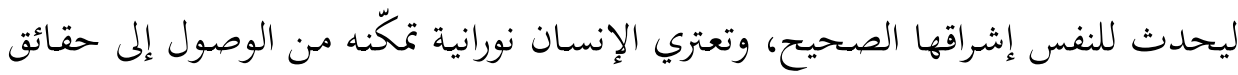

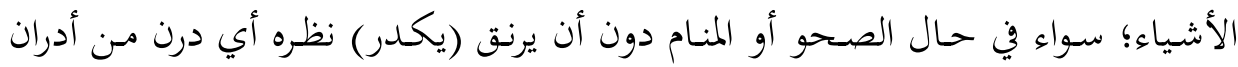
الجمسد. الإسياء

\section{ت. الديانة المصرية القديمة (001 ق.م):}

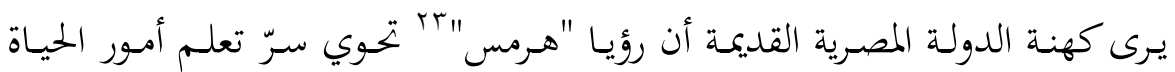

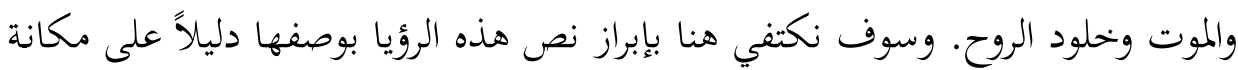

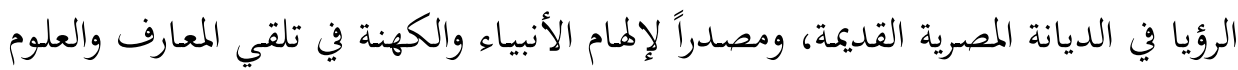

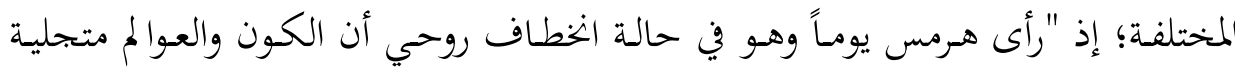

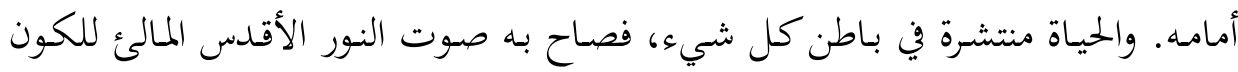

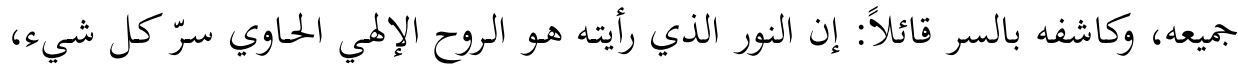

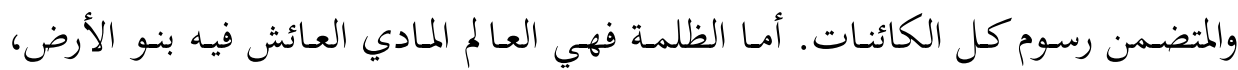

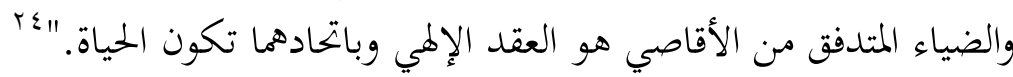

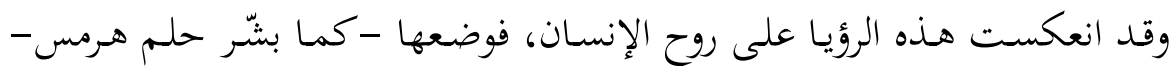

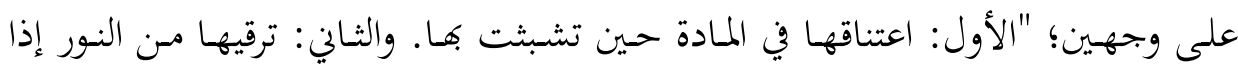

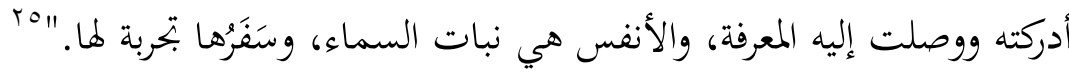

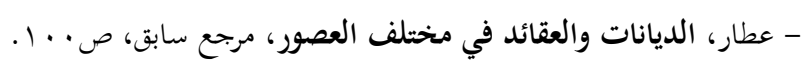

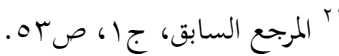

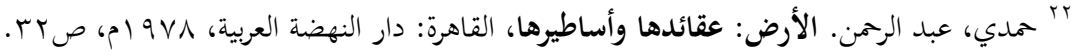

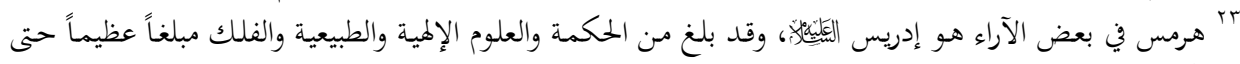

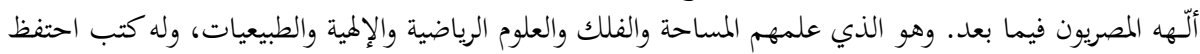

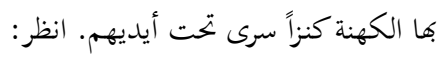

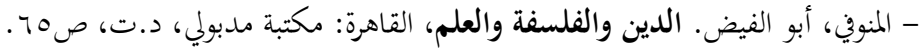

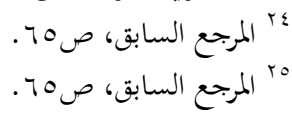


وبذلك تقسم هذه الرؤيا النفوس قسمين: "النفوس الشريرة وهي التي تبقى متعلقة في

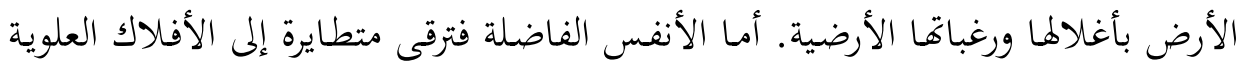

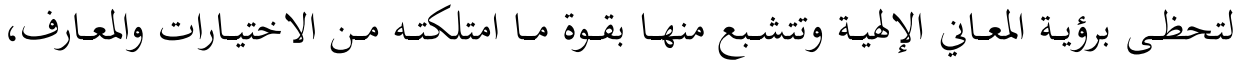

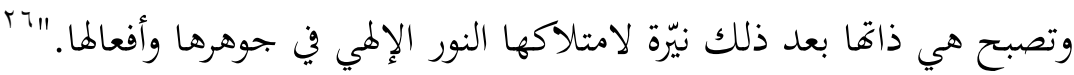

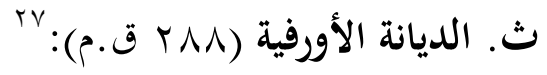

يعتقد أتباع هذه الديانة بأن النفس لا تستيقظ ولا تدب فيها الحياة حتى تتجرّد من

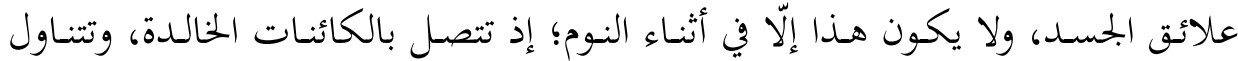

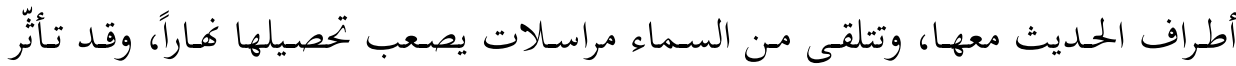

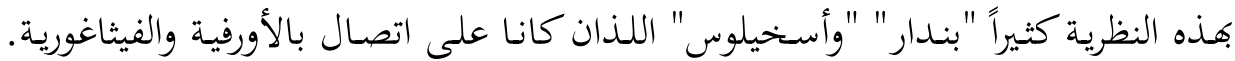

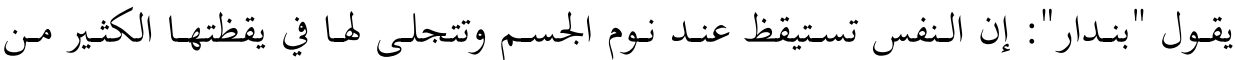

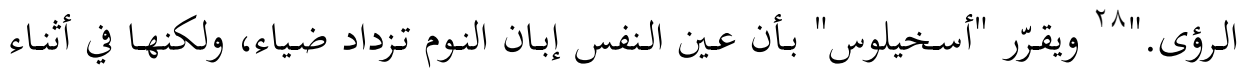
النهار لا تتنبأ بقضاء الإنسان.

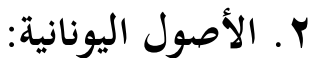

تشكّل الأصول اليونانية، في موضوع الرؤى والأحلام، المصدر الرئيس الذي انحدرت

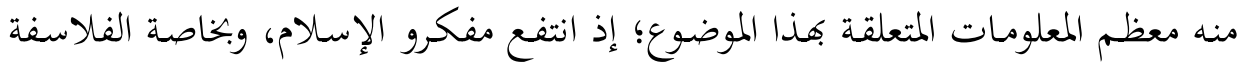

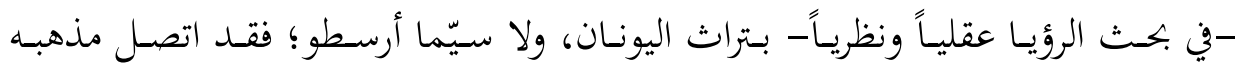

$$
\text { بالشرق الإسلامي عن طريق الكندي، وبالغرب الإسلامي عن طريق ابن رشد. }
$$

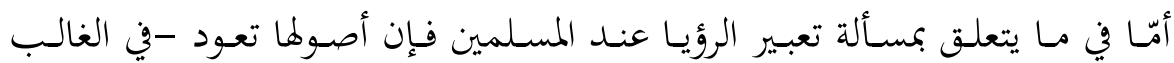

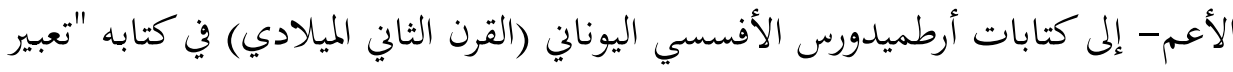

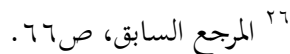

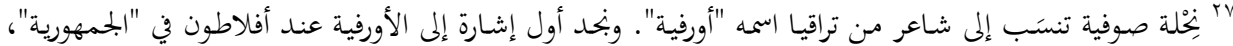

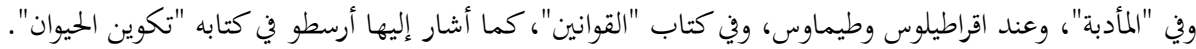

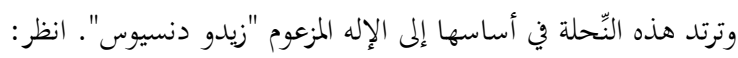

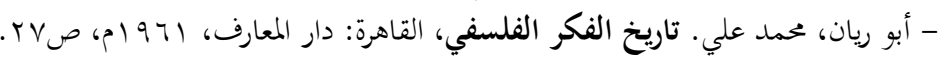
${ }^{28}$ Hasting, James. Encyclopedia of Religion and Ethics, vol. VI, P. 452.

${ }^{29}$.Ibid. vol. V, p. 456 


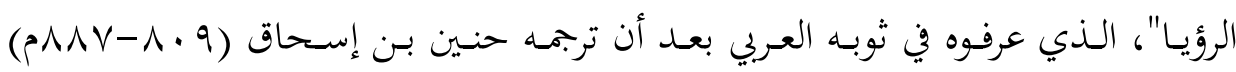

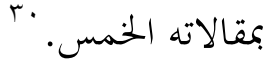

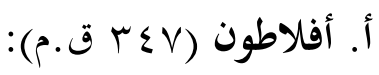

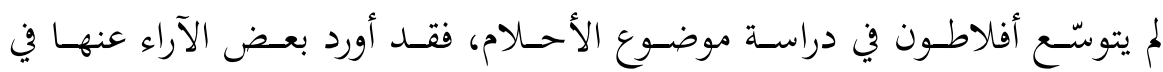

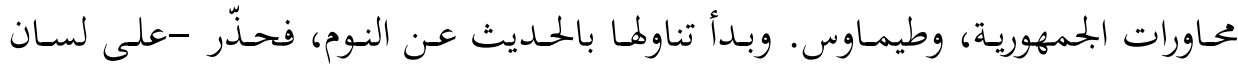

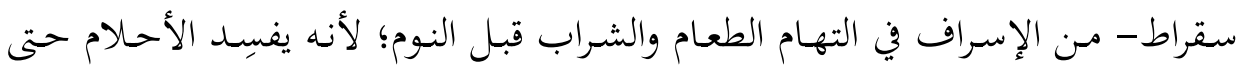

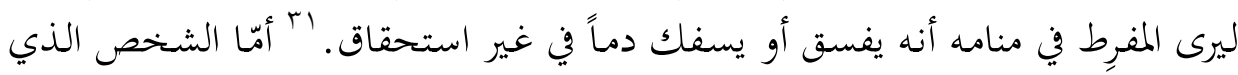

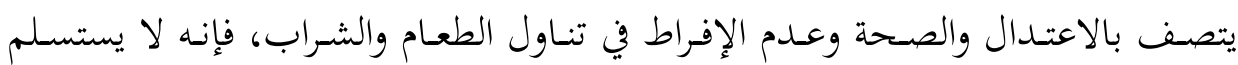

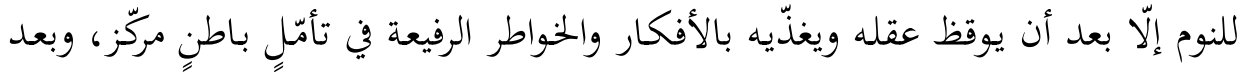

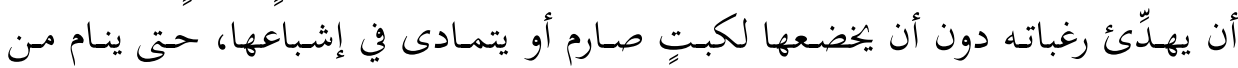

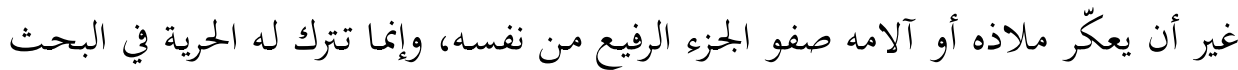

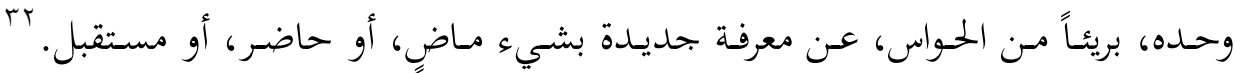

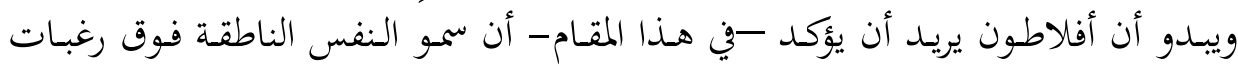

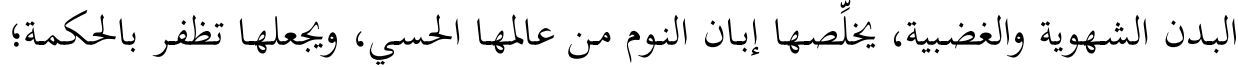

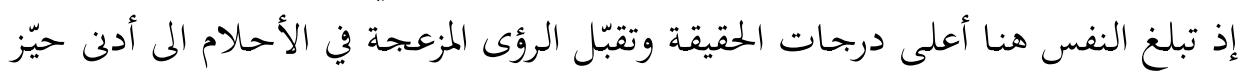

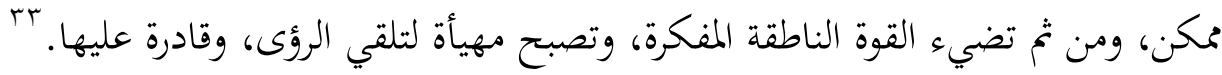
وبوجه عام، فإن أفلاطون يذهب إلى الحطدّ من شأن الأحلام، "ويعزوها إلى الرغبات

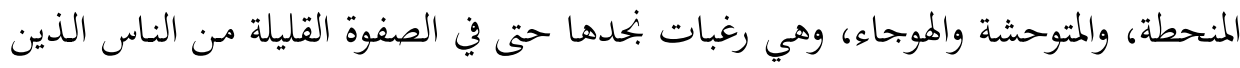

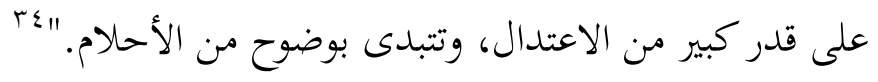

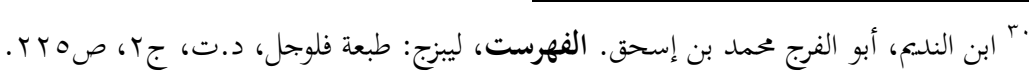

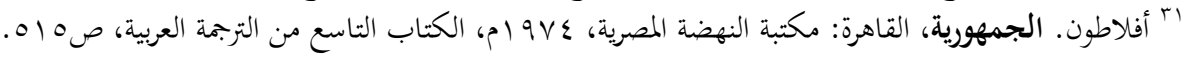

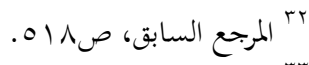

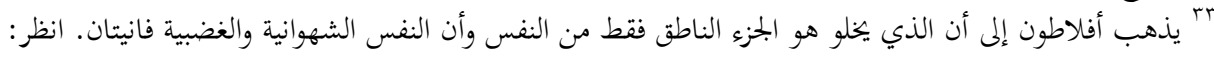

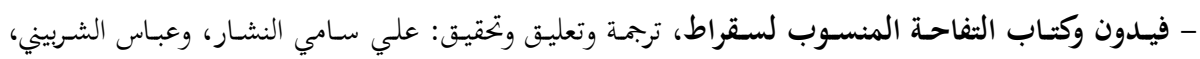

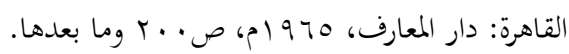

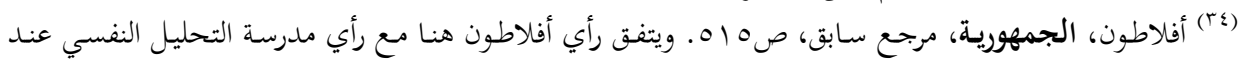

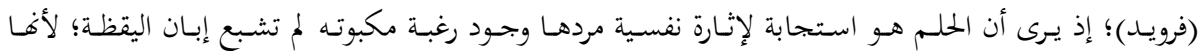




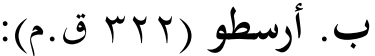

يُعَدّ كتاب "النَّفْس" لأرسطو أحد أهـم المصادر التي استقى منها مفكرو الإسلام بكوث أرسطو المتعلقة بالأحلام. ومما يؤيد هذا الرأي، أن ابن رشد يشير احتئ صراحة إلى هذا

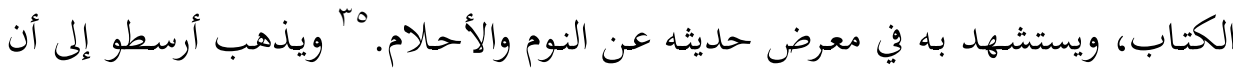

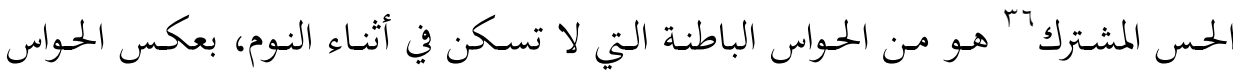

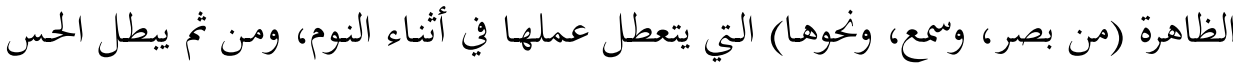

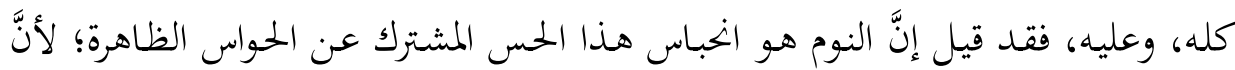

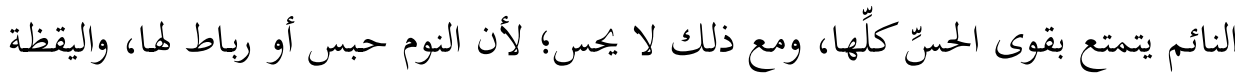
هي إطلاق لهذه القوى.

\section{- المخيلة والأحلام}

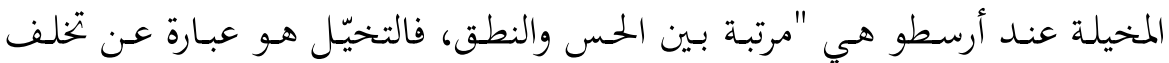

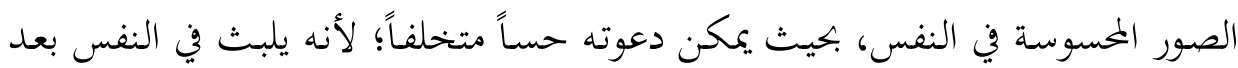

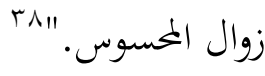

ويذهب أرسطو إلى أن للمخيلة شأناً عظيماً في الأحلام؛ فهي المصدر الذي تنبعث

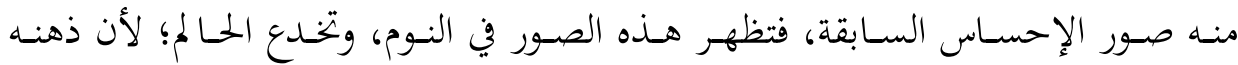
ينصرف عن كل شاغل خهارجي، ولا يستطيع مـا يستطيعه اليقظان مـ مراجعة حاسة

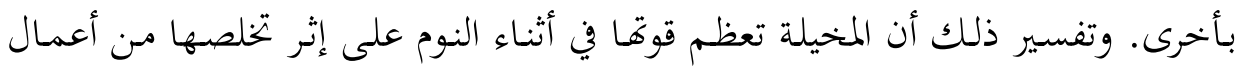

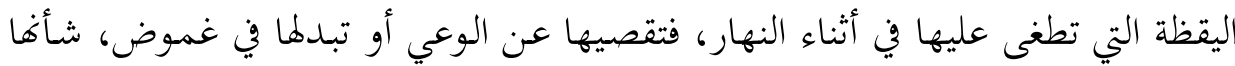

- Freud. Interpretation of Dreams P. 103.

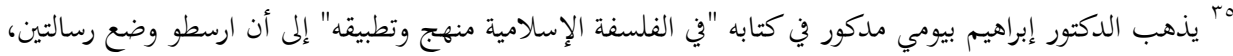

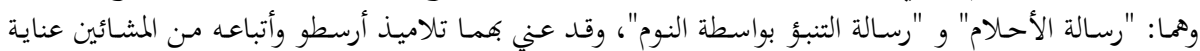

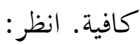

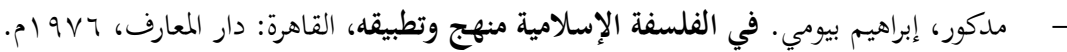

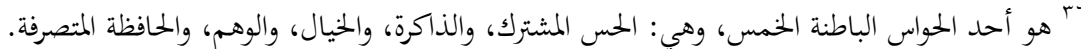

${ }^{37}$ Ross ,S.D. Aristotle (Desommoet vigillia) ,oxford press vol III P. 454.

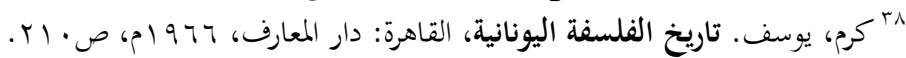




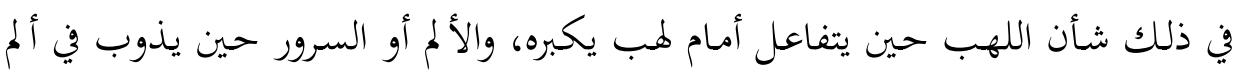

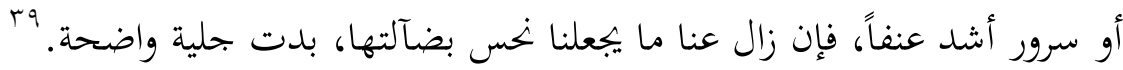

ومعنى ذلك أن الحلم يهوّل الأحاسيس الخفيفة إلى أحاسيس مكبرّة؛ "فالنائم الذي

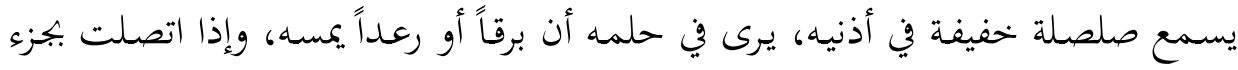

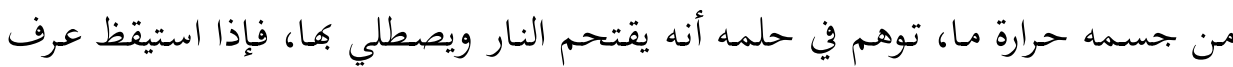

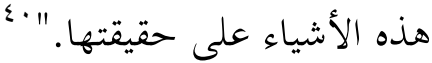

فالأحلام في جملتها عند أرسطو تنشأ من صور ذهنية لإحساسات سابقة تشكلها

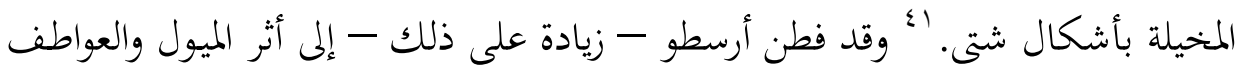

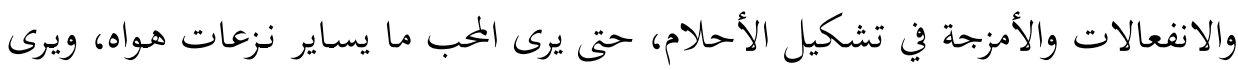

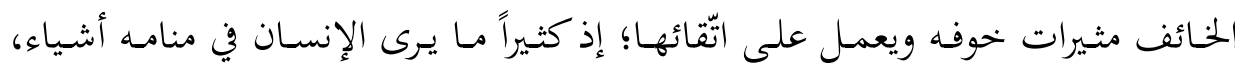

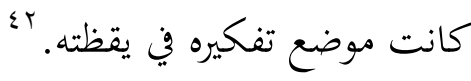

\section{- موقف أرسطو من الرؤيا الصادقة}

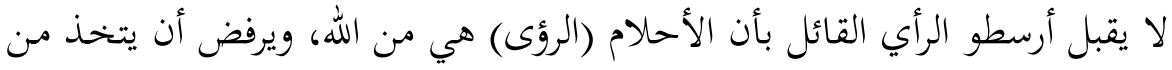

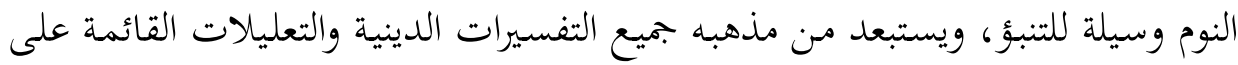

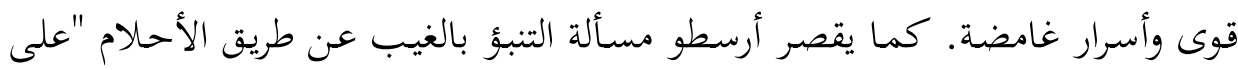

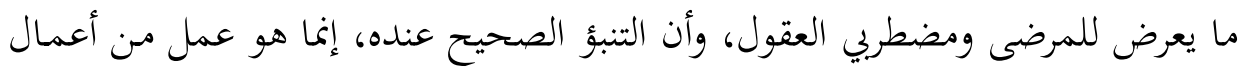

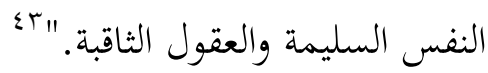

ويجمع الباحثون على أن بحمل آراء أرسطو في الأحلام قد لاقت قبولاً لداء لدى مفكري

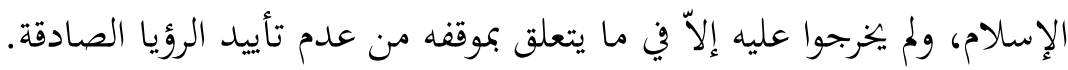

${ }^{39}$ Beare ,John. Greak Theories of Elementary Cognition. Oxford Clarendon Press, 1906, P.P. 51-52.

${ }^{40}$ Ross. Aristotle. Op. cit P. 463.

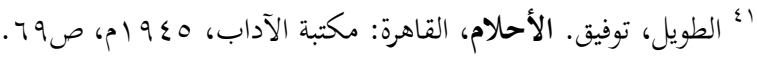

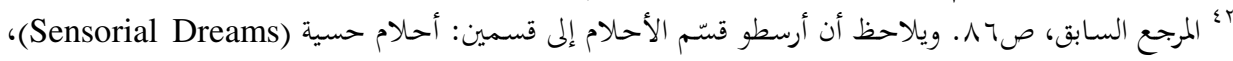
وأحلام نفسية (Psychic Dreams). rأ شيشرون. علم الغيب في العالم القديم، ترجمة وتعليق: توفيق الطويل، مصر: دار النهضة العربية، د.ت، ص19. 


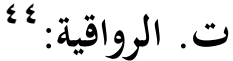

تمثّل آراء الرواقية في الأحلام رافداً رئيساً من روافد التراث القديم، ولا سيّما اليوناني

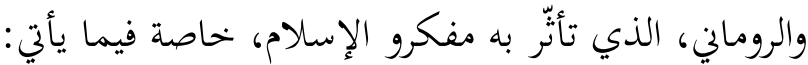

\section{- النفس الإنسانية والننبؤ بالغيب}

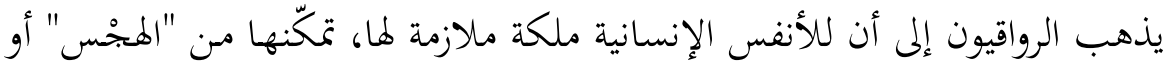

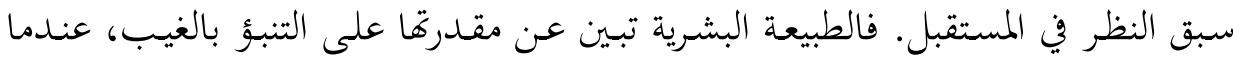

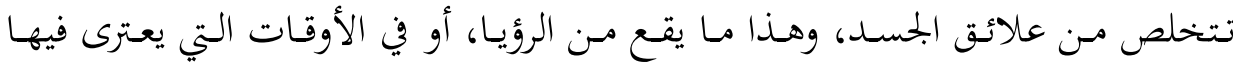

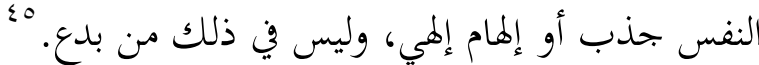

فالنفس يمكنها أن تدرك الغيب بفطرتا حين تتجرّد من علائق الجسد وتتخلص من

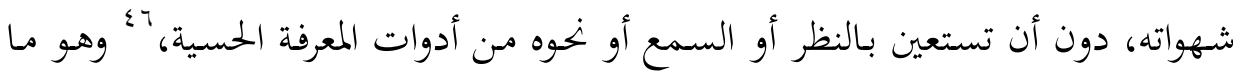

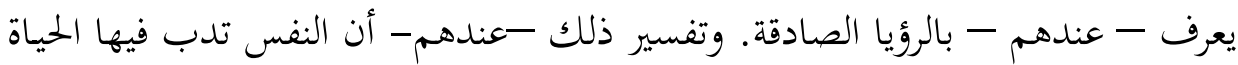

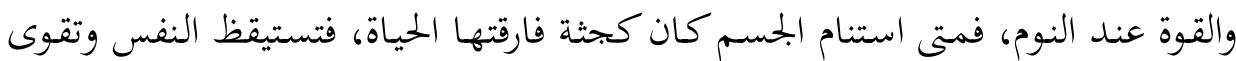

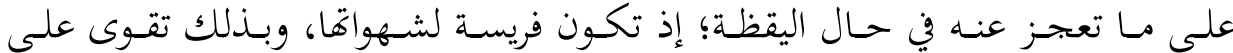
التنبؤ.

وقـد تأثّر متصـوفة الإسـلام بهـذا الرأي، فَعـدّوا النوم أخهاً للمـوت؛ فـالموت إذا نـزل

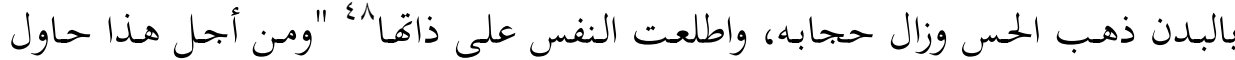

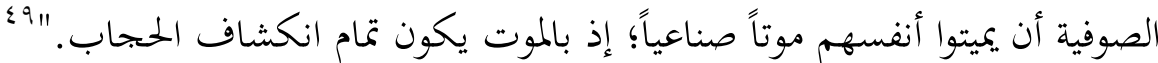

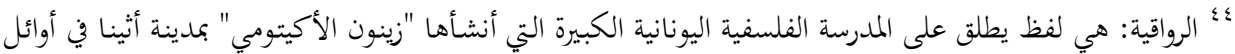

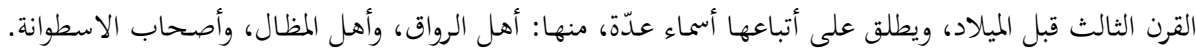
- الشهرستاني، أبو الفتح تاج الدين بن عبد الكريم. الملل والنحل، تحقيق: محمد كيلاني، بيروت: دار المعرفة،

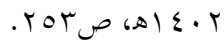

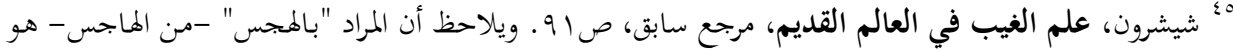

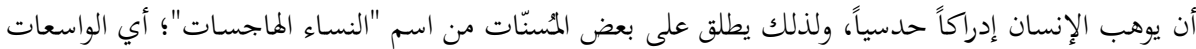

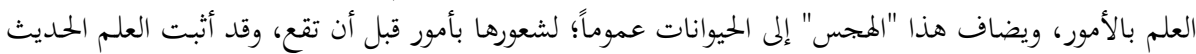

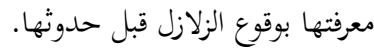

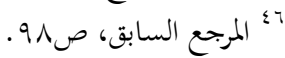

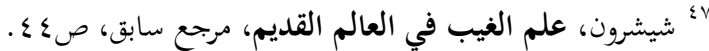

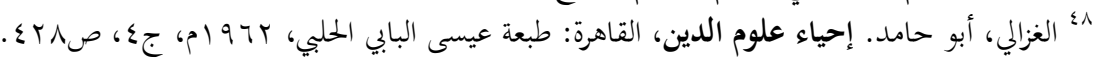


ويفرّق الرواقية - كالمسلمين - بين الرؤيا التي تكون من الله، والحلم الذي هو مـن

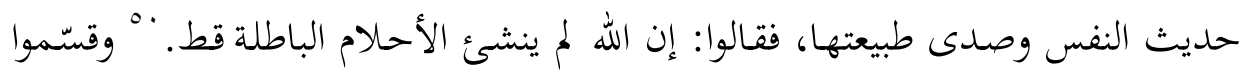

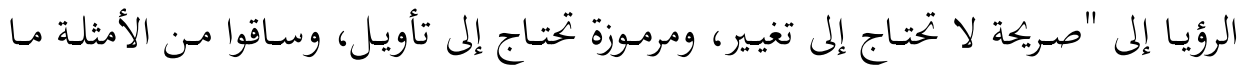

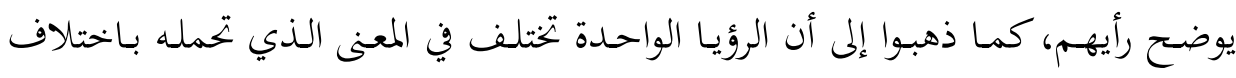

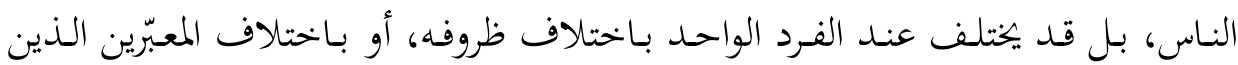

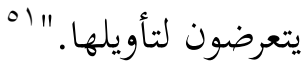

وقد لاحظ "شيشرون" في معرض حديثه عن أتباع الرواقية أهمم لا يرون بأساً مـن

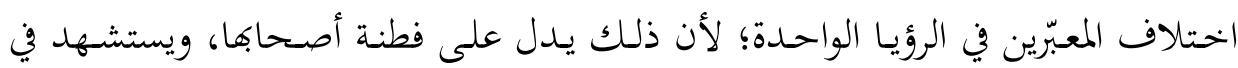

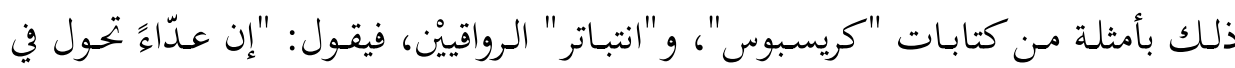
المنام إلى "نسر" فعبّر الرؤيا أحد المعبّرين بالنصر، باعتبار النسر أسرع الطيور، وأوّهلها غيره

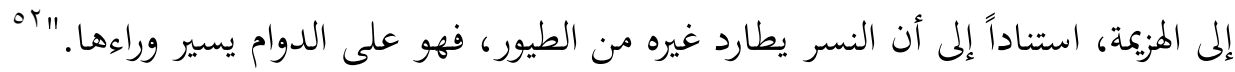
ويضع الرواقيون "للمعبّر" صفات تشبه نظرة المسلمين من بعض الوجوه، فهو "أقدر

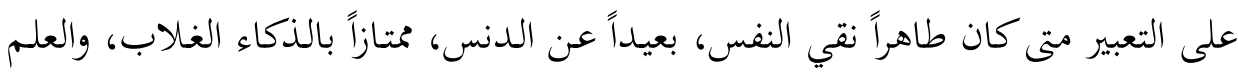

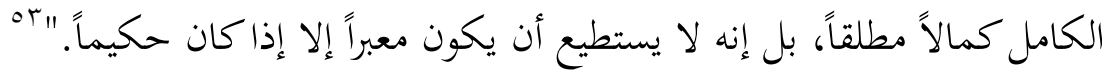

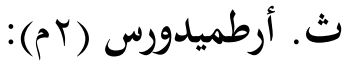

أرطميدورس الأفسسي هو صاحب كتاب "تعبير الرؤيا" والمؤسس الحقيقي لعلم تعبير

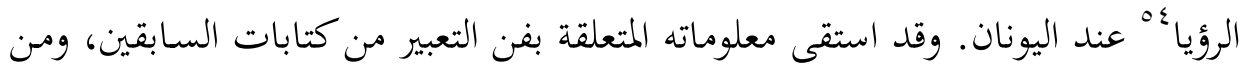

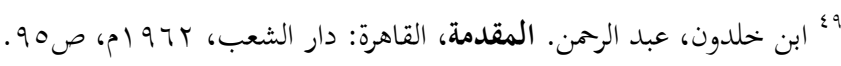

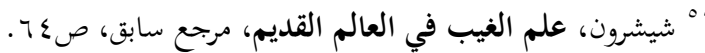

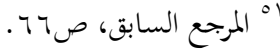

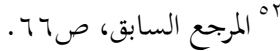

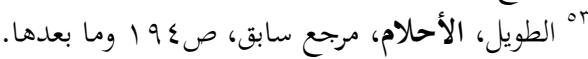

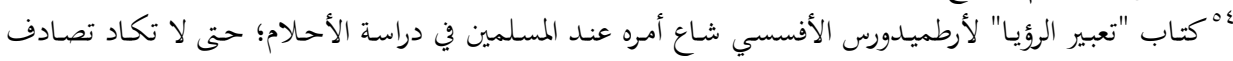

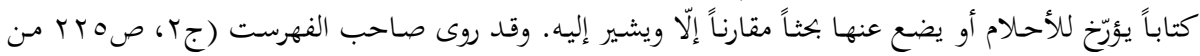

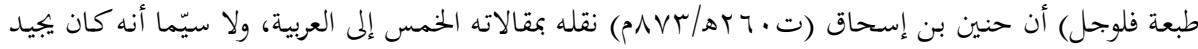

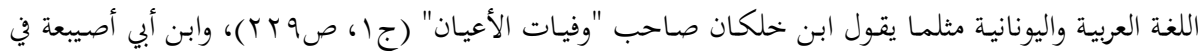

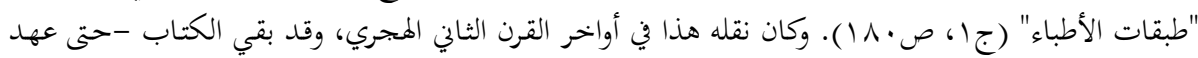


بتاربه الشخصية وعشرته للناس، واختلاطه بالمشتغلين بالكهانة والعرافة - على اختلاف أهوائهم - فضلاً عن رحلاته التي استغرقت أعواماً طويلة في آسيا وإيطاليا وبلاد اليونان

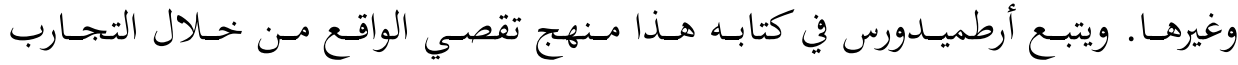

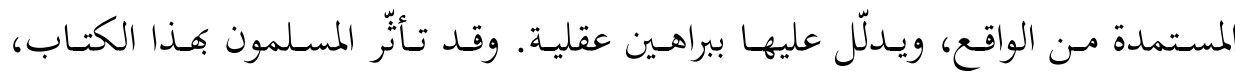

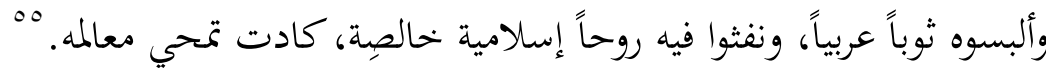

ويقسم أرطميدورس الأحلام قسمين؛ الأول: الصريح الذي لا يحتاج إلى تعبير؛ فهو

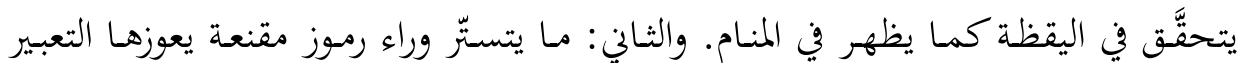
(التأويل)، فيكون في صورة بحازية. ويسوق على هذا أمثلة يوضّح بها ما ذهبب إليه من آراء، فيقول: "الرؤى (إما) ظاهرة ومنها ذوات تأويل. أما الرؤيا الظاهرة فهي التي تكون مثل الشيء الذي تـل عليه، مثل إنسان يرى كأنه في البحر، وكأن البحر هـاج عليه وتموج فلما أصاب ذلك بعينه، وذلك أنه سار في البحر وهلكت سفينته، ولم يسلم ممن كان فيها أحسد إلا هو ونفر يسير. ومثل إنسـان رأى كأن رجالاً قد طعنه، فلما أصبح وخرج من موضعه ضربه ذلك الرجل ضربة على كتفه في الموضع الذي رأى في منامه أنه ضربه... أما الرؤى ذوات التأويل فهي التي يرى الإنسان فيها في منامه شيئاً فيدل ذلك

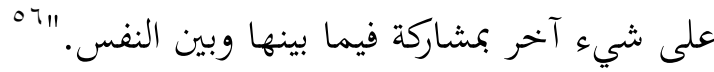

قريب- في عداد المفقودات، إلى أن اكتشف المخطوط فؤاد سزكين، ثم نشره توفيق فهد (دمشق، ع 97 (م)، وقد

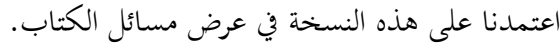

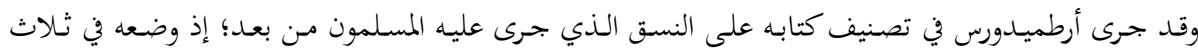

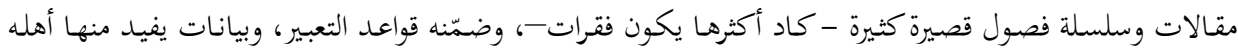

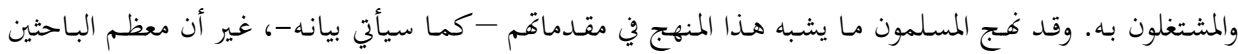

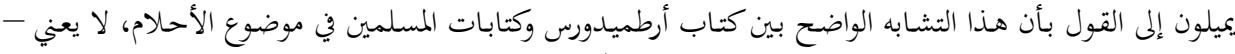

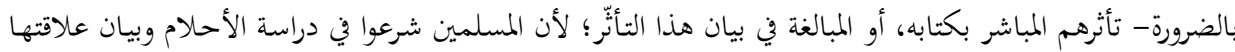

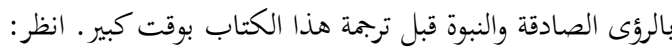

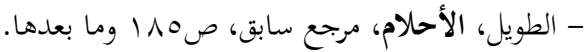

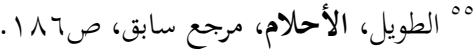

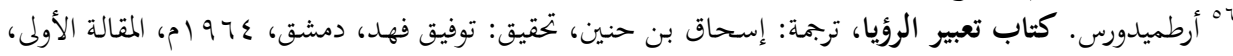


والرؤى عند أرطميدورس تنقسم إلى ما هو محمود، وما هو مذموم، ويضرب مثالاً

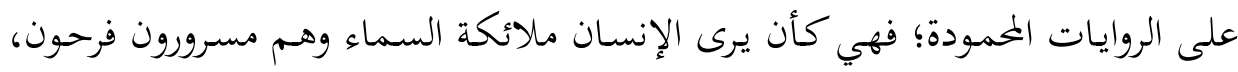

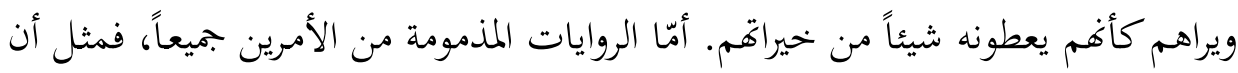

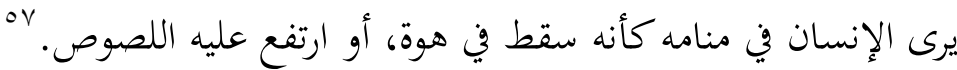
ويفرّق أرطميدورس بين الحلم والرؤيا، فيقول: "الرؤيا تخالف الأضغاث (الأحلام)،

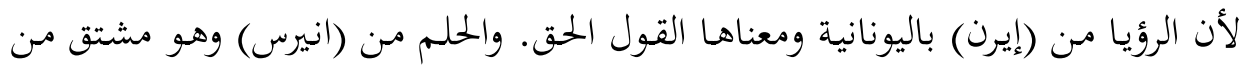

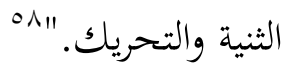

وإلى مثل هذه التقسيمات يذهب علماء المسلمين، مع بعض الاختلافات التي تتفق

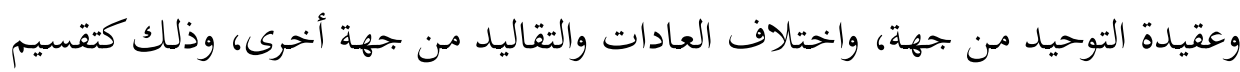

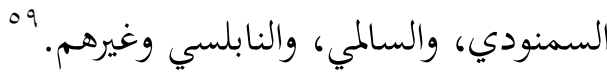
وتسهم الرمزية إسهاماً فاعلاً في تأويل أرطميدورس للمؤى والأحسلام، وفي مـا يأتي

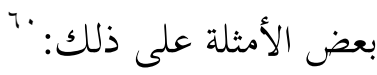

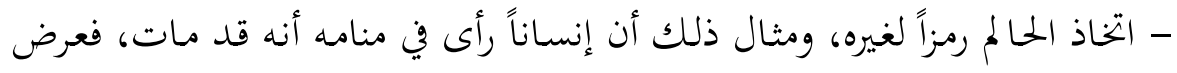

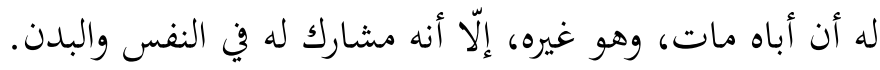

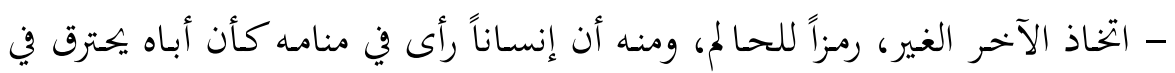

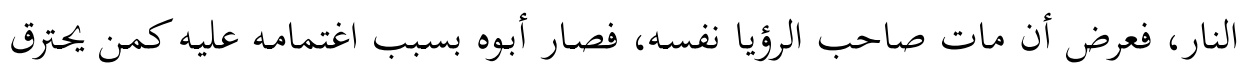

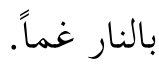

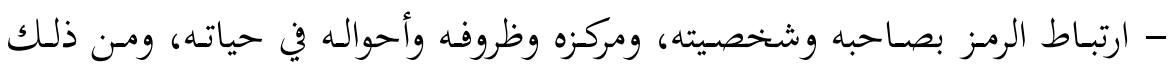

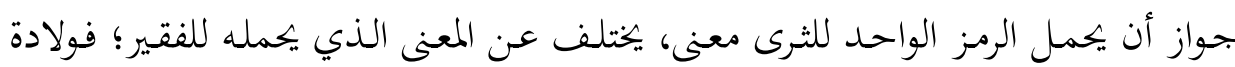

$$
\begin{aligned}
& \text { "المرتع السابق، صوجr. }
\end{aligned}
$$

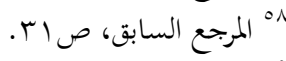

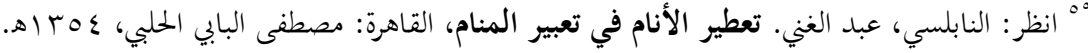

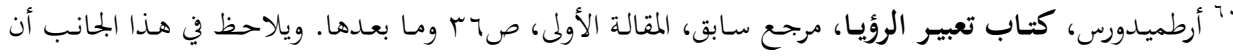

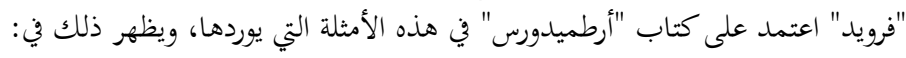

- Freuds. Interpretation of Dreams, op. cito, p.89. 
الطفل في الرؤيا إذا وقعت للفقير أصاب خيراً ورزقاً، وإذا وقعت للغني فَقَدَ سلطانه على

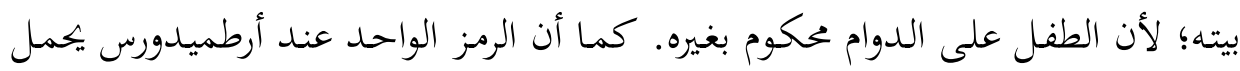
كثيراً من المعاني التي تختلف باختلاف الأمهم والشعوب والمللل، وتتباين عند الأفراد بتباين ثقافتهم وتقاليدهم وصناعاتم وطرائق معيشتهم ونحو ذلك، وهذا هو فهم المسلمين أيضاً للرمز

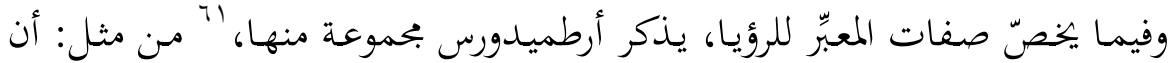

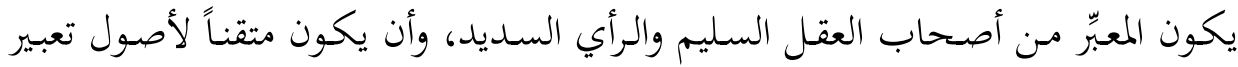

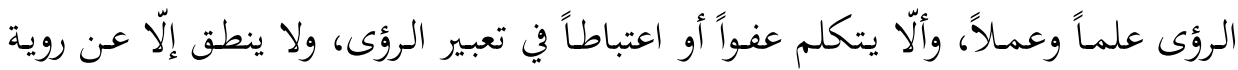

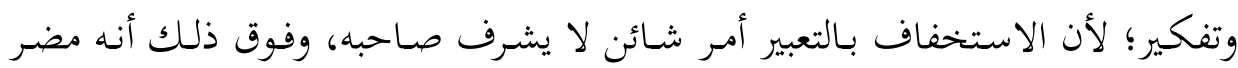
لصاحب الرؤيا، كذلك أن يظل على اتصال يصاحب الرؤيا للاستفسار عمّا خفي عنه

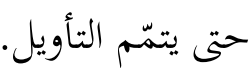
أمّا بالنسبة إلى تأثير أرطميدورس في علم تعبير الرؤيا عند المسلمين، فقد أجمع عليه

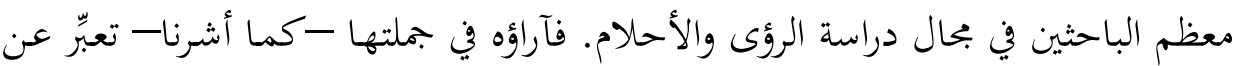

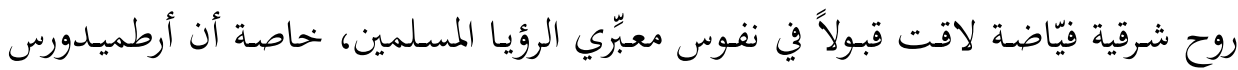

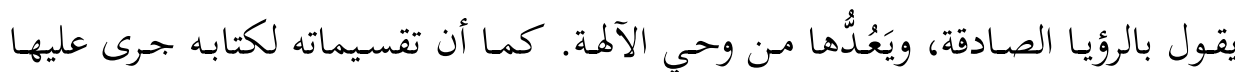
المسلمون من بعد.

يقول توفيق الطويل في التعبير عن هذا التأثّّ : "إننا إذا جرّدناكتاب أرطميدورس من صيغة الوثنية اليونانية، وجرّدنا ما يقابلها من آراء المسلمين - على نحو مانيو ما سيأتي تفصيله

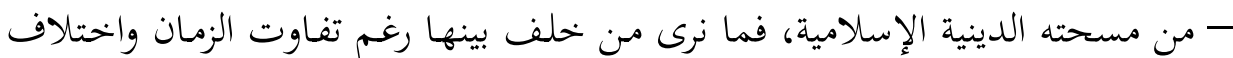
المكان لأفها عامـة ومشتركة، وهكذا نلاحظظ أن تفكير المسـلمين في هـذا الصـدد، كـان

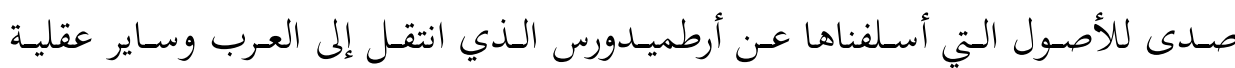

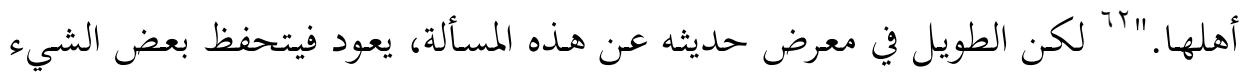

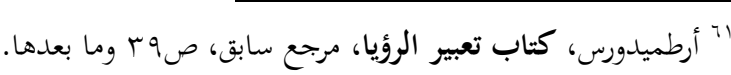

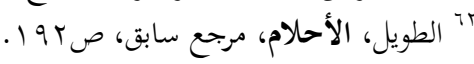


في قبول هذا الرأي الذي أعلنه؛ إذ يقول: "ينبغي ألا نبالغ في نقل المسلمين عن غيرهم،

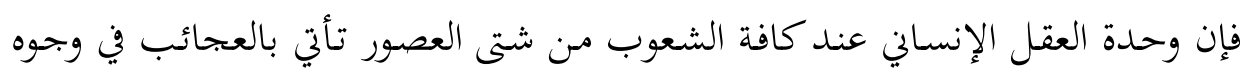

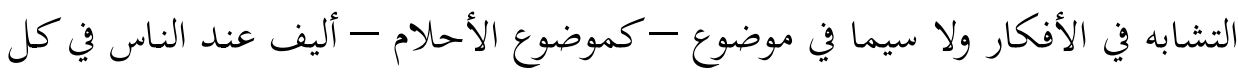

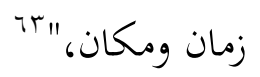

ويمضي الطويل في تأكيده هذا التحفظ، فيقول: "إن ترجمة حنين بن إسحق لكتاب

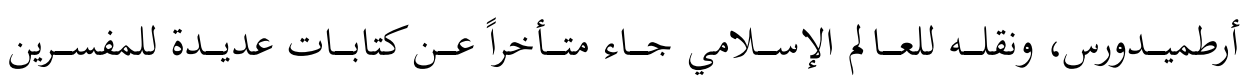

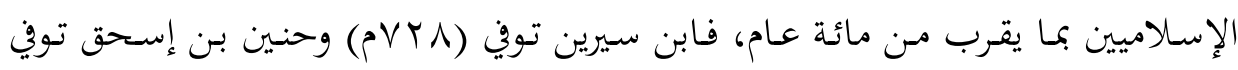

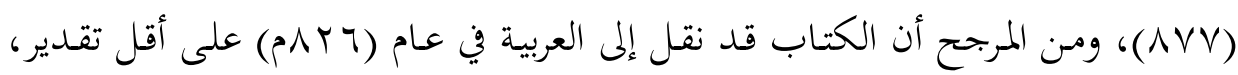

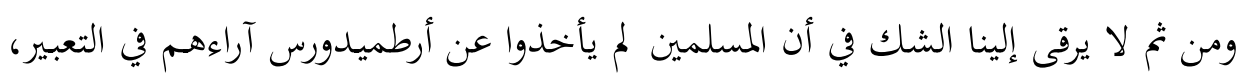
اللهـم إلا إذا قيـل إن أفكـاره وصـلت إلـيهم قبـل ترجمتـه في اقتباسـات المشـتغلين بهــا

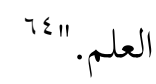

ثالثاً: موقف الفِرَق الإسلامية من الرؤى والأحلام

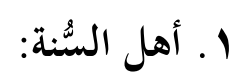

يأخـذ السُّنة بمنهج تقسيم الرؤى إلى قسمين (الرؤيا الصادقة، والحلم)، استناداً إلى

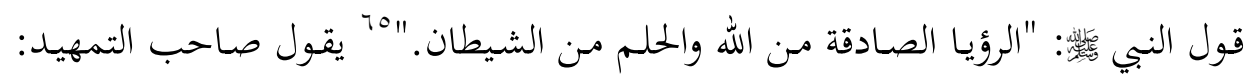

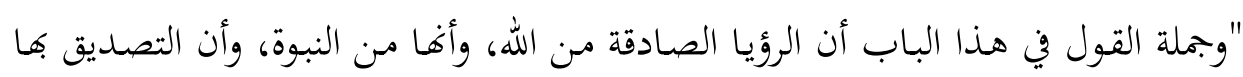

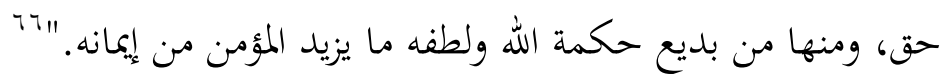

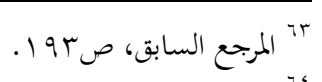

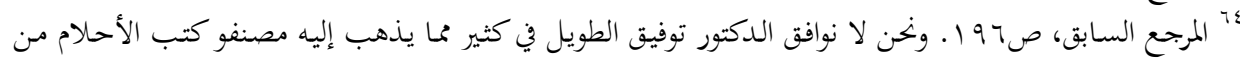

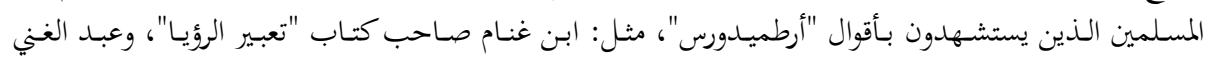

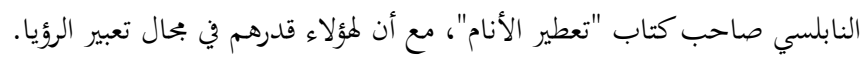

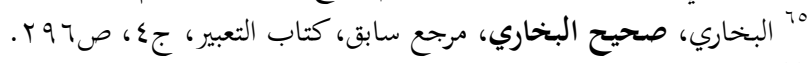

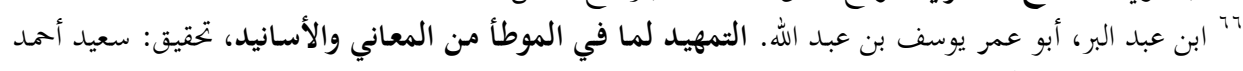

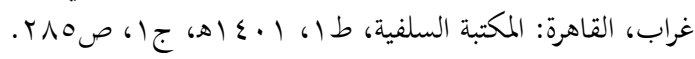


ويقسم أهل السنة الرؤيا الصالحة إلى أربعة أقسام؛ لَّأولها: إلهام يلقيه الله -سبحانه

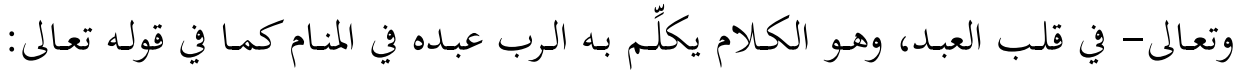

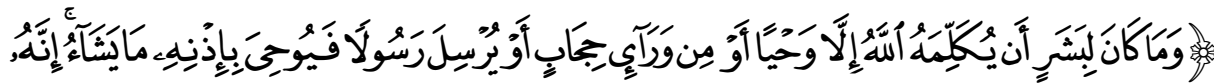

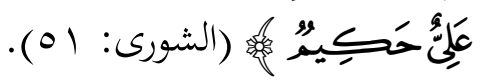

ويرى ابن تيمية أن الوحي هو الإعلام السريع الخفي، إما في يقظة أو في المنام، فإن

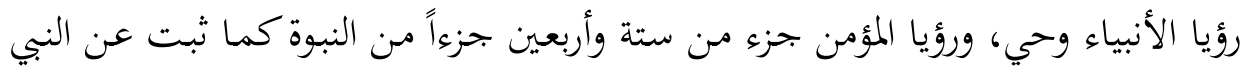

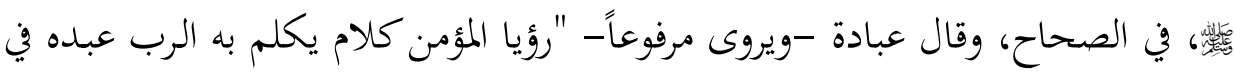

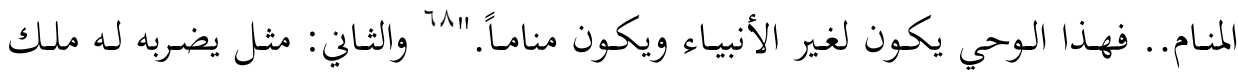

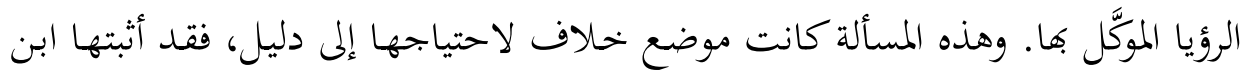

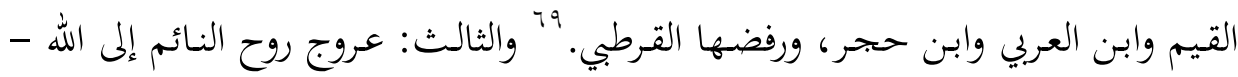

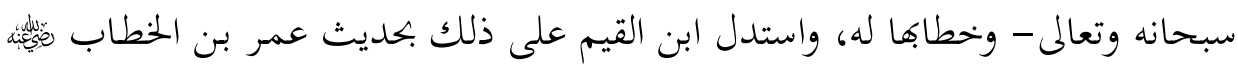

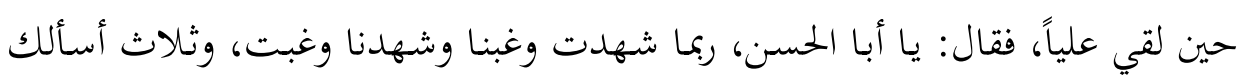

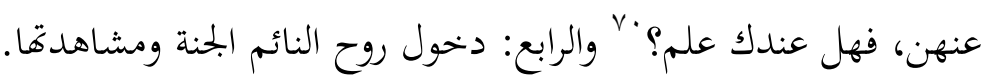
وتكمن أسباب صدق الرؤيا الصالحة عند السلف في ثلاثة أمور:

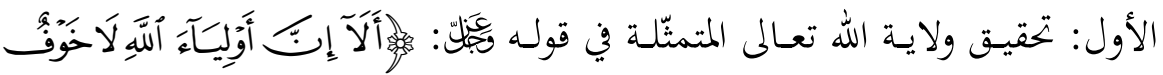

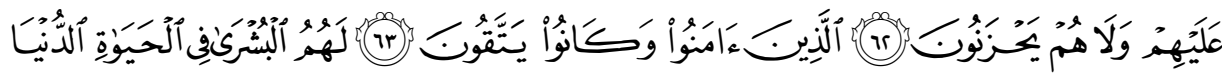

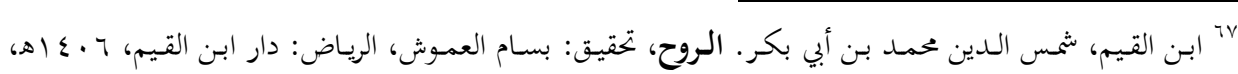

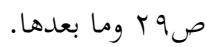

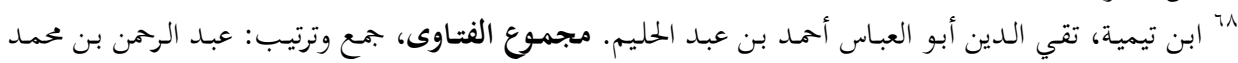

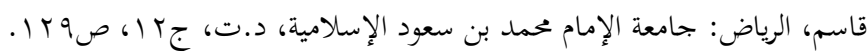
19

- ابن القيم، شثس الدين محمد بن أبي بكر. إعلام الموقعين، تحقيق: طه عبد الرؤوف سعد، بيروت: دار الجيل،

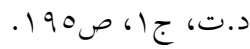

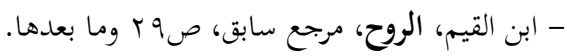

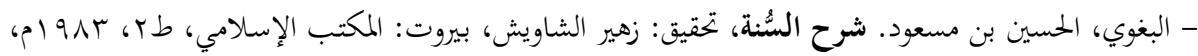

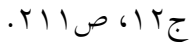

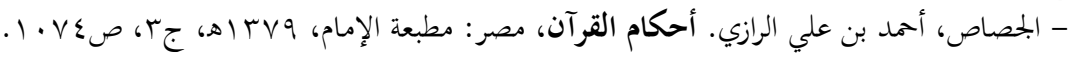

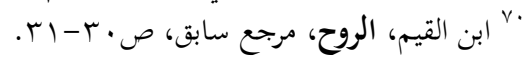




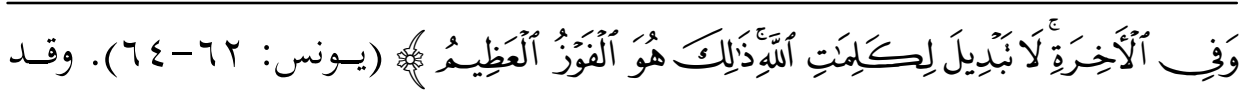
ورد تفسير البشرى في الحياة الدنيا في الأحاديث الصحيحة بأفها الرؤيا الصالحة.

والثناني: الحـرص على الصـدق في الحـديث. فقــ أخـرج الإمـام أحمـد في مسـنده مـن

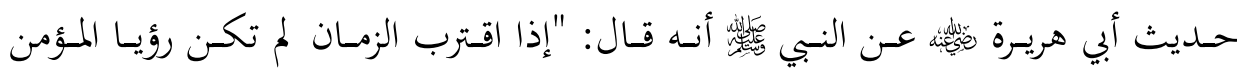

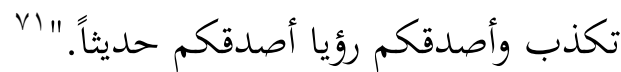

والثالث: الحِرْز مـن الشيطان عند النوم؛ وذلك بمراعـاة آداب النوم التي جـاءت في السنة النبوية، ومنها: النوم على طهارة، والتعوذ والقراءة عند النوم (قراءة آية الكرسي، وآخر آيتين من سورة البقرة، والمعوذات).

ويذهب ابن القيم إلى "أن رؤيـا الأنبياء وحي؛ وأهـا معصومة مـن الشيطان، وهـا

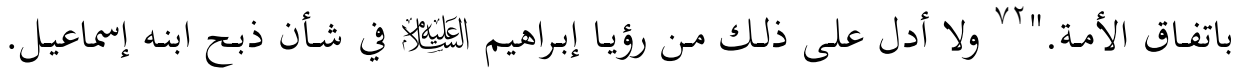

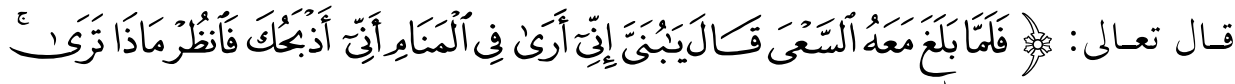

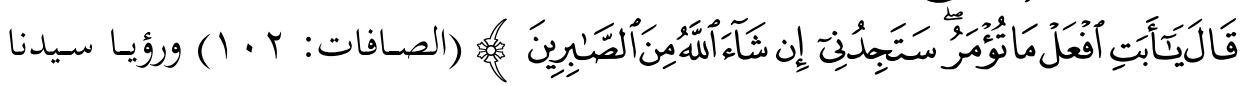

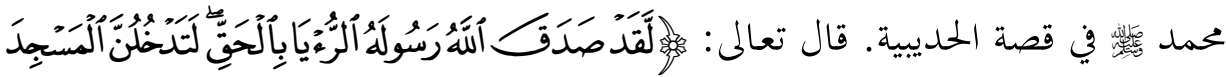

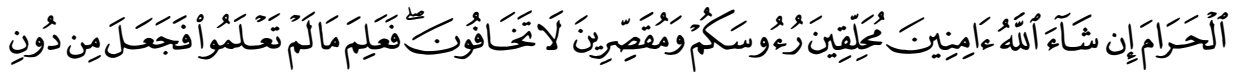

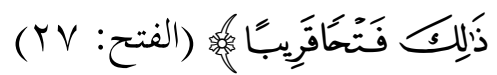
ورؤيا الأنبياء تقع وحياً لأسباب عدّة منها: العصمة من تمثّل الباطل أو الشيطان أو الخيال لهم في صورة الحق؛ ولذلك فرؤياهم حق. واتصاف جميع لافيع الأنبياء -عليهم الصلاة

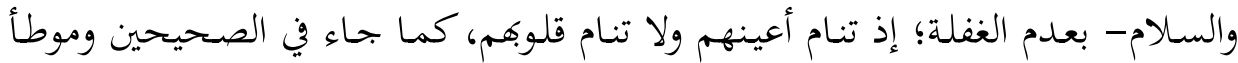

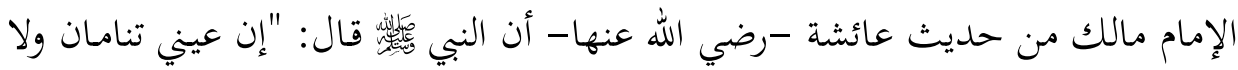

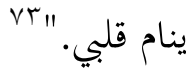

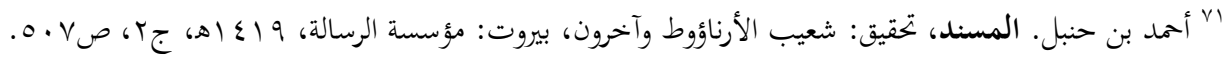

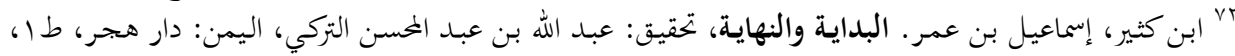

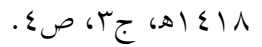

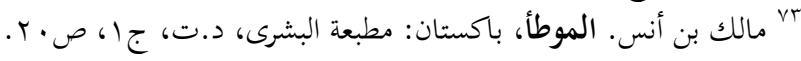




\section{أ. علم تعبير الرؤيا عند أهل السُّنة: ع}

يَعُدّ علماء السنة علم تعبير الرؤيا علماً صحيحاً دلّ عليه الكتاب والسنة والواقع

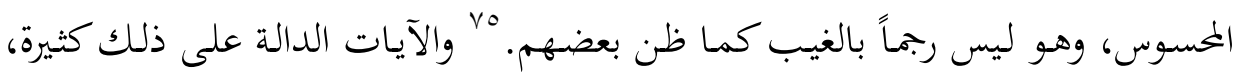

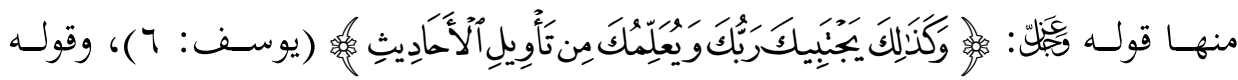

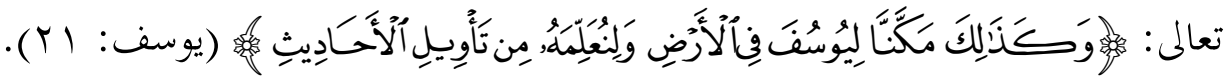
وقد دلت السُّنة على صحة هذا العلم في أكثر مـن حديث وموضع، منها: ما ورد في كتاب "بدء الوحي"، الحديث الثالث، أخرج لسنده عن عائشة -رضي الله عنها- أهـا

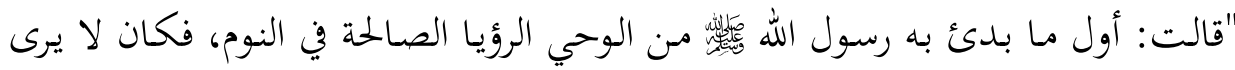

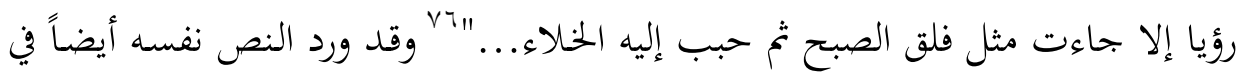

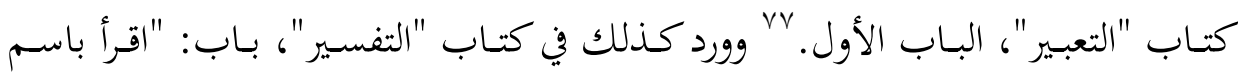

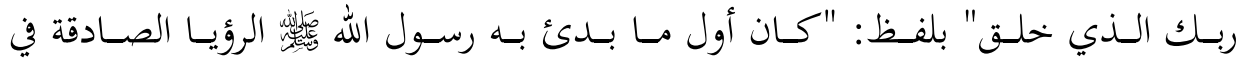

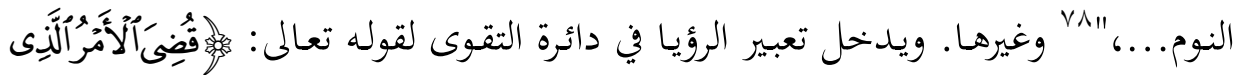

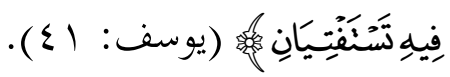

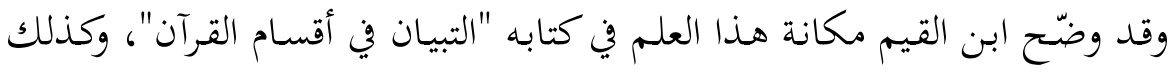

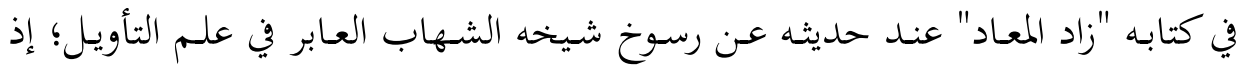

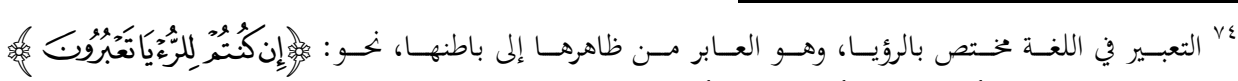

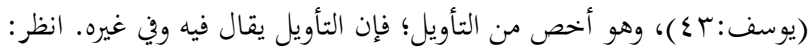

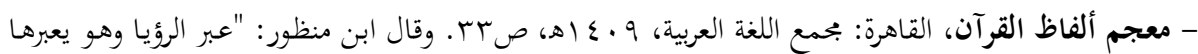

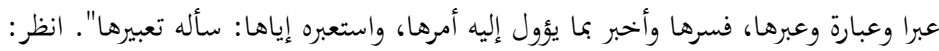

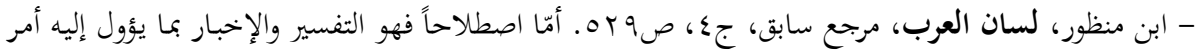

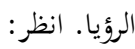

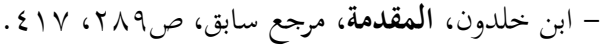

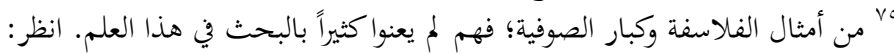

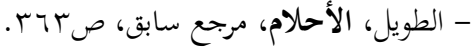

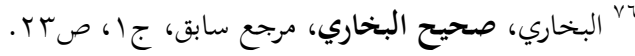

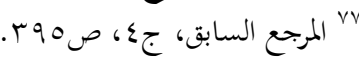

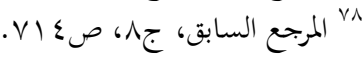


يقول: "وهذه كانت حال شيخنا هذا، وسوقه في علم التعبير، وسمعت عليه عدة أجزاء،

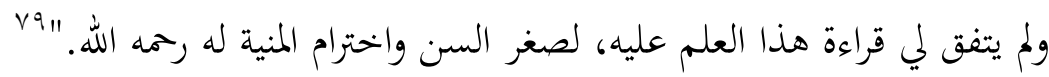

ويفـرّق ابـن تيميـة بـين التعبير والتأويـل، فيقـول: "فالحاصـل أن تأويـل الرؤيـا يشـمل

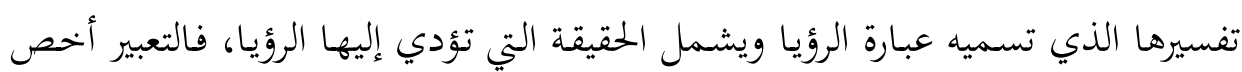

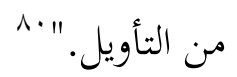

ويقسم علم التعبير الرؤيا إلى نوعين: الأول: ما هو ظاهر لا يحتاج إلى تأويل، ومثاله

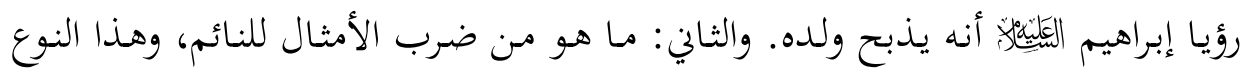
هو الأكثر والغالب على الرؤيا، وهو الذي يحتاج فيه إلى تأويل، ومثاله رؤيا يوسف اليَّلنِّلَ.

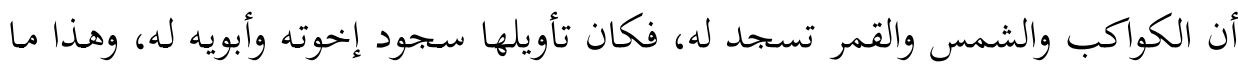

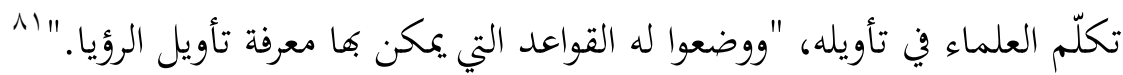
ويذهب ابن تيمية إلى أن "الرؤيا تدرك بالمقايسة والاعتبار.... وذلك أيسر من إدراك

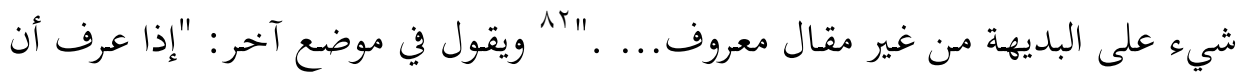

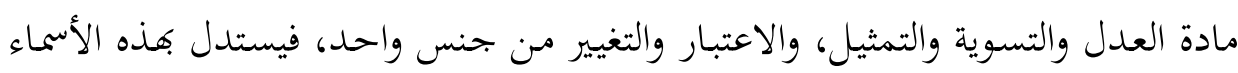
على القياس الصحيح الفعلي والشرعي ويؤخذ من ذلك تعبير الرؤيا." ويقـول ابـن القيم في المعنى نفسـه: "لقـد ضـرب الله سبحانه الأمثال وصـرفها قـدراً

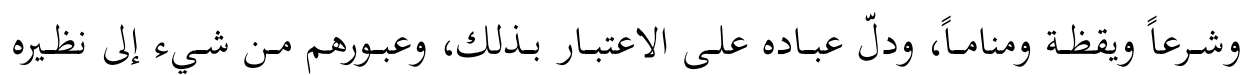

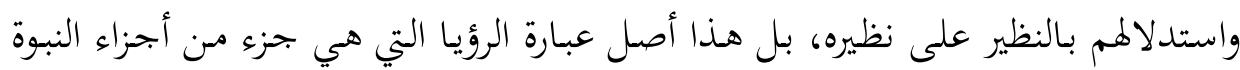

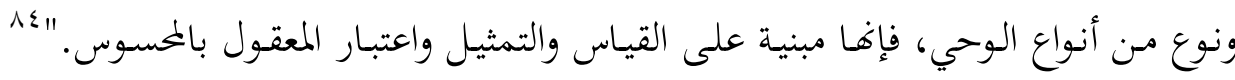

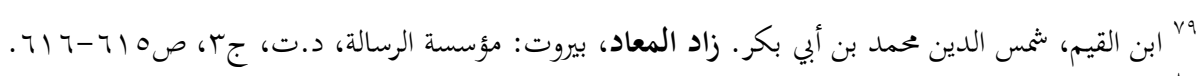

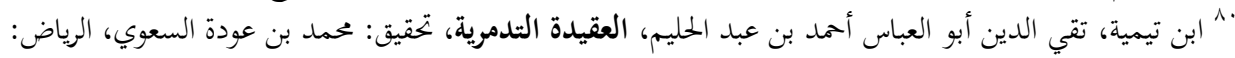

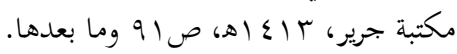

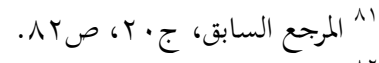

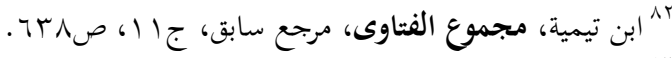

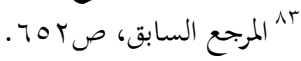

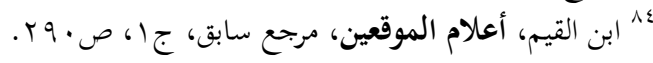


ويعبِّر محمــ بن سيرين عن المعنى عينه بقوله: "والعبارة قياس واعتبار وتشبيه وظن، لا لا

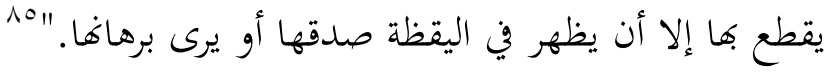

فالحماصـل مـن كـلام هـؤلاء العلمـاء أن تعبـير الرؤيـا يعتمـــ علـى القيـاس والاعتبـار

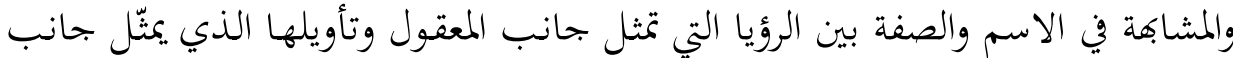

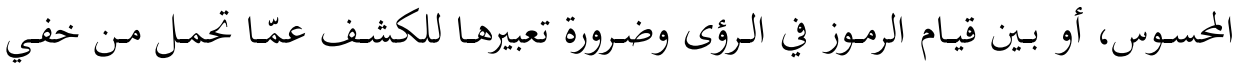
المعاني.

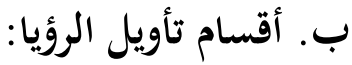

يقول البغوي في كتابه "شرح السُّنة": "واعلم أن تأويل الرؤيا ينقسم أقسـاماً، فقـد

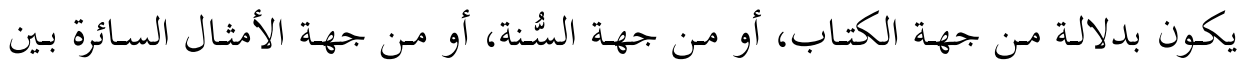

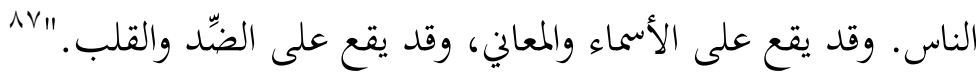
وين ما يخصّ التأويل بدلالة القرآن، يرى ابن القيم "أن فهم القرآن يعبر عن الرؤيا

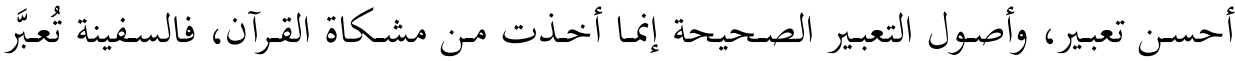

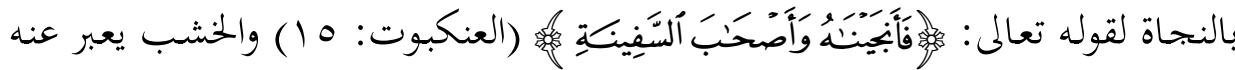

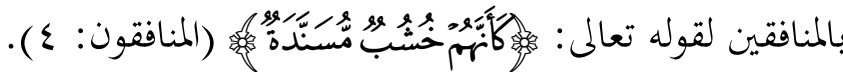

أمّا عن التأويل بالحديث فيقول ابن سيرين: "والعابر يحتاج أيضاً إلى اعتبار أخبار رسول الله

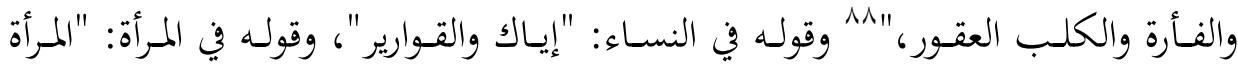

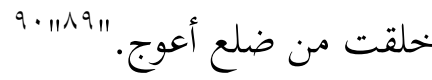

ه^ ابن سيرين، أبو بكر محمد. الإشـارة في علم العبارة، تحقيق: خالد علي محمد، الرياض: مكتبة الصفحات

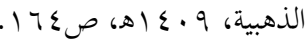

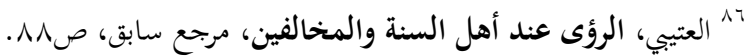

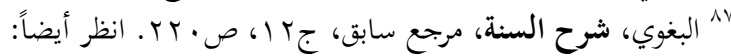

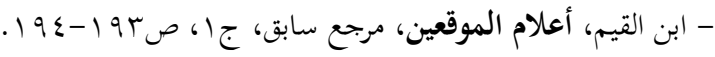

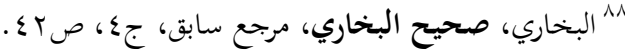

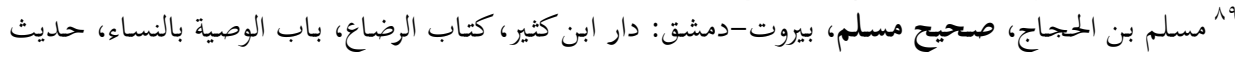


ومن التأويل بالأقوال السائرة بين الناس، قول إبراهيم لإسماعيل عليهما السلام: "غيِّّ

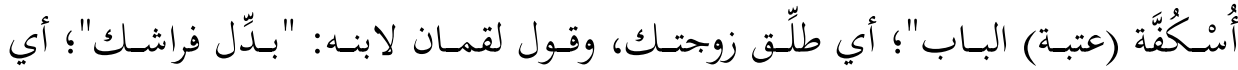

والتأويـل بدلالــة المعـاني فيـه الكثير، وهـو الغالـب في تأويـل الرؤيـا، ويظهـر بصـورة

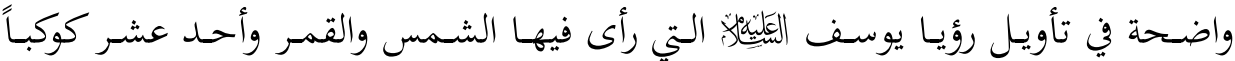
ساجدين؛ إذ إن وجه المناسبة فيها أن هذه الأنوار هي زينة السماء وجمالها وبها منافعها،

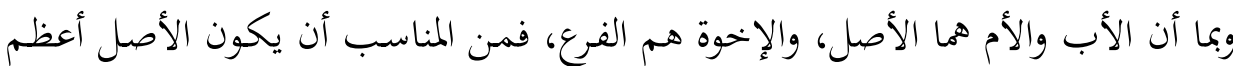

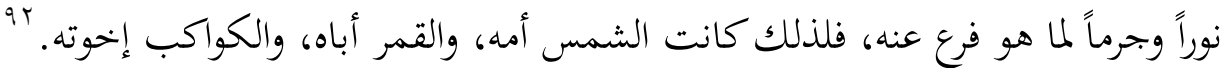
ووهـن المناسـب أن الشـمس لفـظ مؤنــث، فكانــت لأمـه، وأن القمـر والكواكــبـ

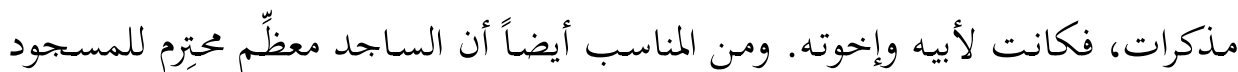

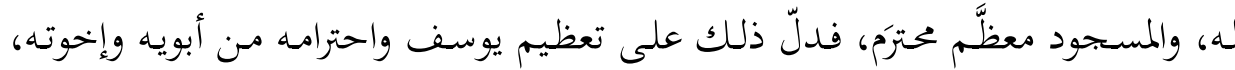

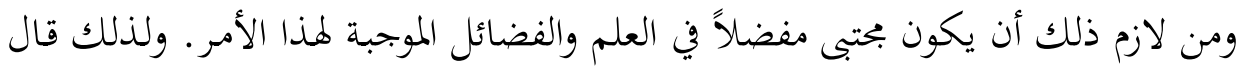

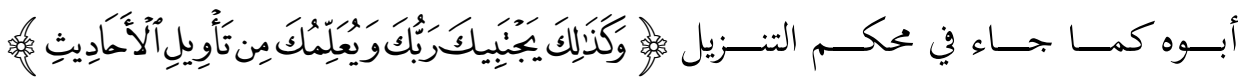

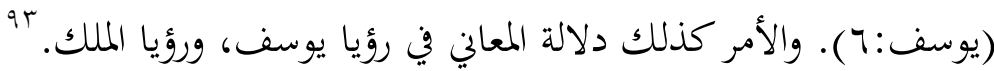

يتطرق السلف بعد ذلك إلى وضع قواعد وآداب لتعبير الرؤيا، يجب على الرائي أن

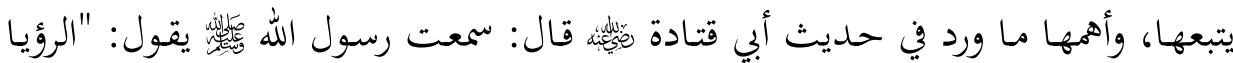

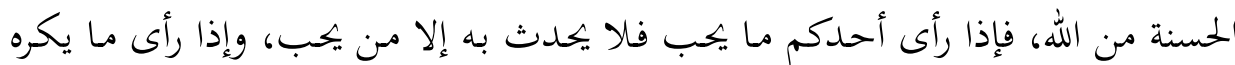

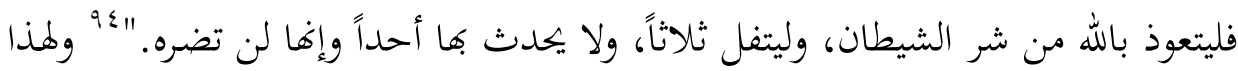

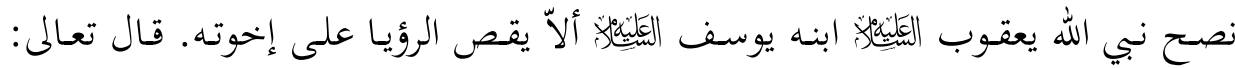

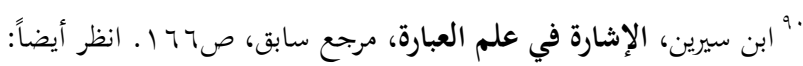

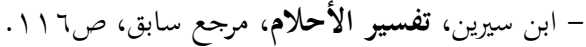

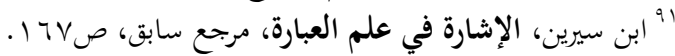

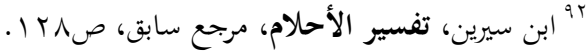

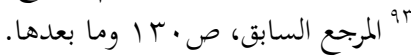

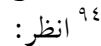

$$
\begin{aligned}
& \text { - البخاري، صحيح البخاري، مرجع سابق، كتاب التعبير، ج؛، ص9 . r. }
\end{aligned}
$$


眾 (يوسف: 0).

ينتقل أهل السنة بعد ذلك إلى وضع شروط للمعبِّر، منها: 90 أن يكـون عالمـاً متفقهـاً في الكتـاب والسـنة، مـع مزيـــ فهـم ومعرفـة، وأن يكـون

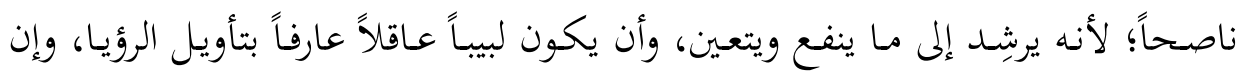

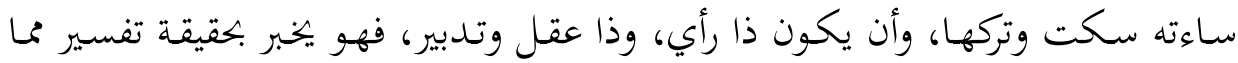

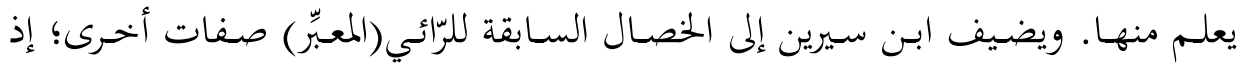

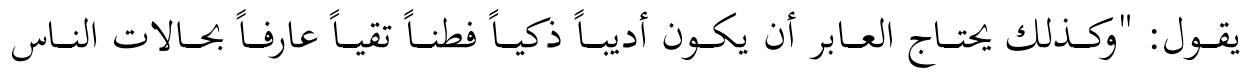

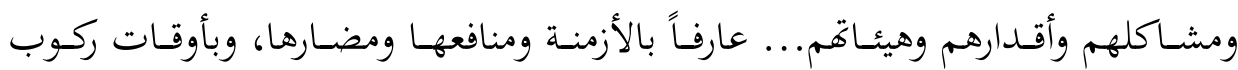

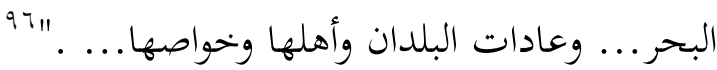

$$
\begin{aligned}
& \text { أمّا آداب المعبِّ فقد حددها السلف في الآتي: }
\end{aligned}
$$

- إذا وردت على الرائي(المعبِر) من صاحب الرؤيا في تأويل رؤياه عورة قد سترها الله عليه، فلا يخبره منها بما يكره أن يطلع عليه مخلوق غيره إن كان مبتلياً لا حيلة له. - أن لا يصدر الرائي(المعبِّر) في تأويله في مسألة حتى يفتشها، "وكان ابن سيرين

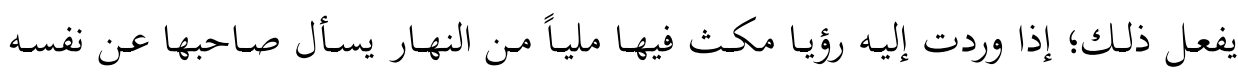

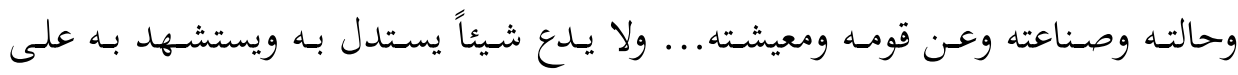

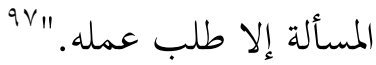

- أن يتصف الرائي (المعبِّر) بالطهارة والنـزاهة والأمانـة وتحري الصـدق. يقـول ابن القيم: "ويعتمد علم التعبير على طهارة صاحبه ونزاهته وأمانته، وتخريه الصدق والطرائق

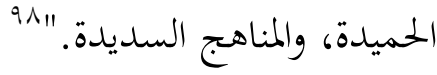

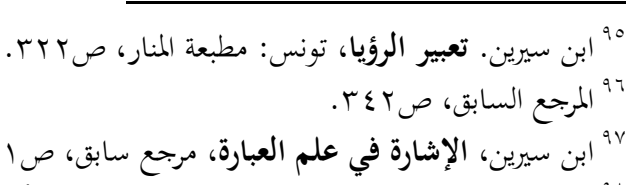

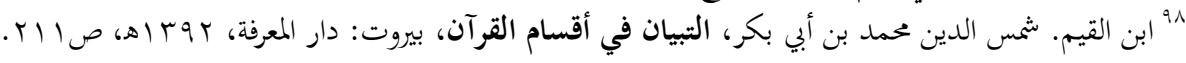




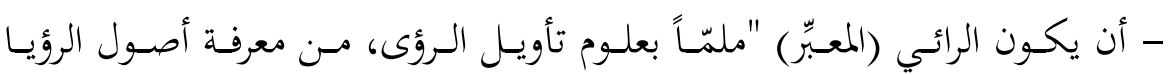

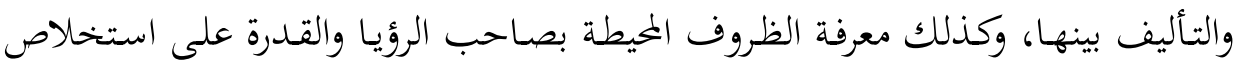

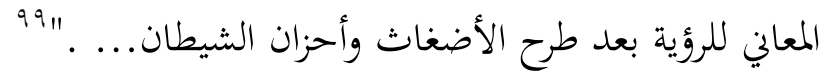

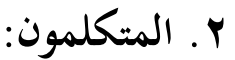

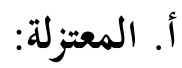

تبلورت آراء المعتزلة في الرؤى والأحلام في كتابات القاضي عبد الجبار، والزخشري

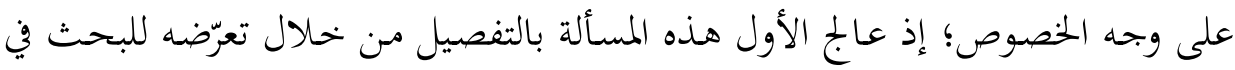

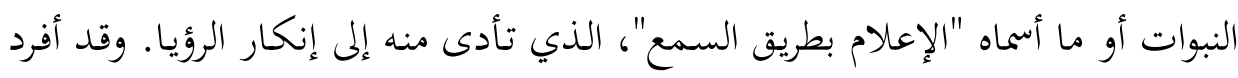

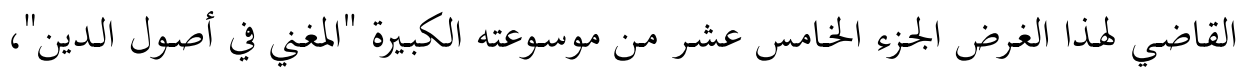
وقد أسماه "النبوات"، وكتاب "تثبيت دلائل النبوة".

ويذهب القاضي عبد الجبار إلى أن الإعلام عن الغيب هو من أهم دلائل النبوة،

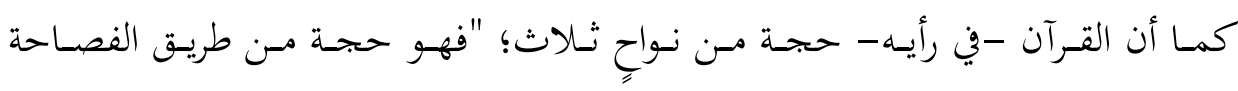

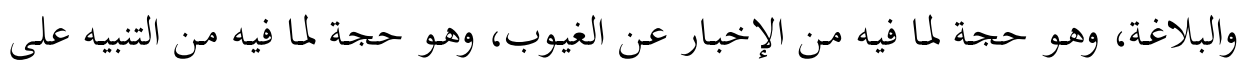

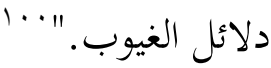

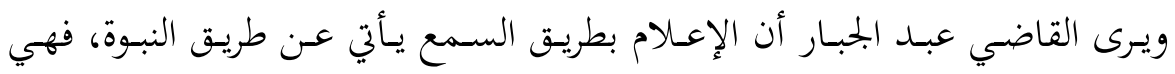

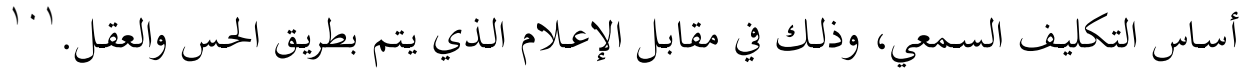

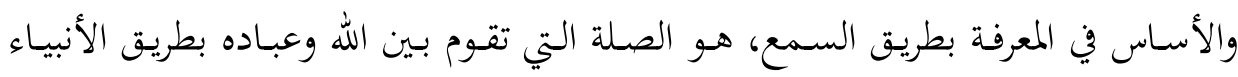

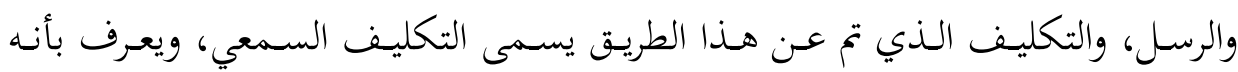

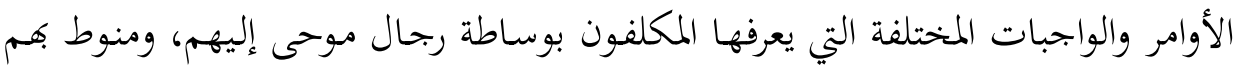
تبليغ ما نزل عليهم من رسالات.

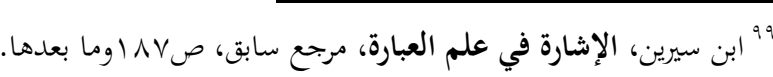

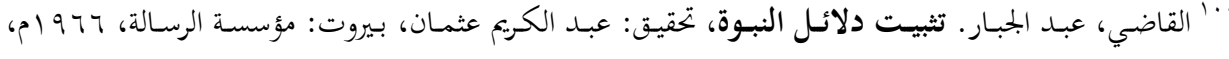

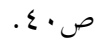

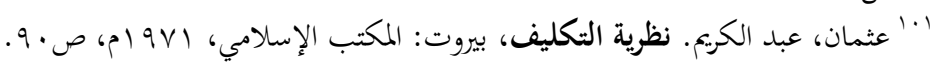


وما دامـت تلك هي نظرية النبوة عنـد القاضي التي يقوم عليها الإعـلام بالسـمع، واستنباط الأدلة السمعية - كما أشرنا - وكانت الوسيلة في ذلك هي الوحي والمعرفة الإلهامية، التي يرى القاضي عبد الجبار أهما مقصورة على الأنبياء فقط دون غيرهم؛ لذلك تجده - كما أشرنا - ينكر الرؤيا بكل أنواعها، ويرفض إمكان إهان التنبؤ بالغيب لغير الأنبياء

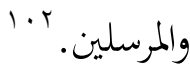

أمّا الزخشـري فيذهبب -على عكس ذلكـ- إلى إثبـات الرؤى مـن خـلال تفسيره

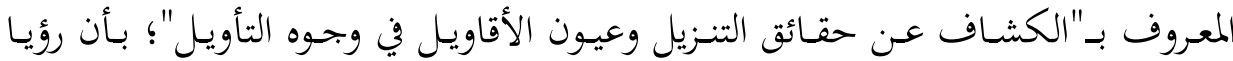

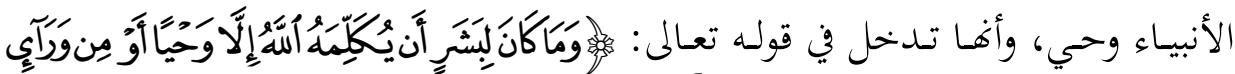

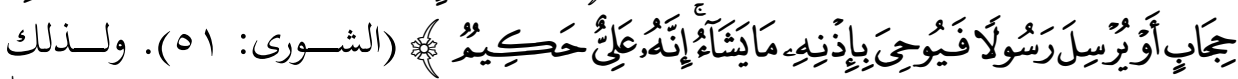
ذكر الله تعالى بعض رؤى أنبيائه، فمن ذلك قوله لِّيَّلَ:

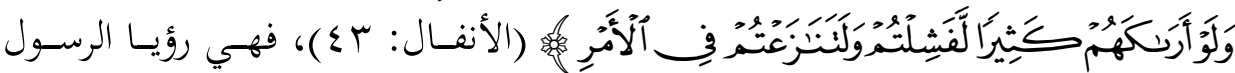

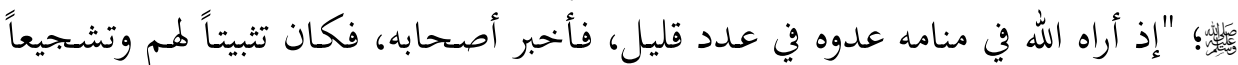

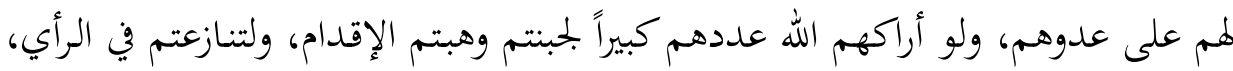

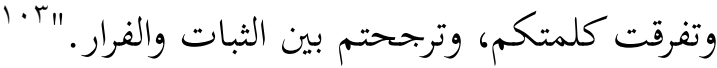

ويذهب الزخشري -على خلاف أهل السنة- إلى القول بأن الرؤيا -إجمالاً- هي

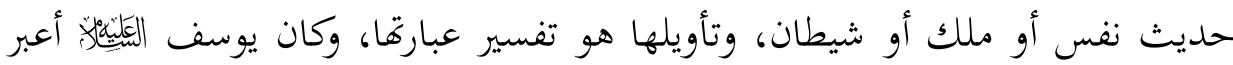

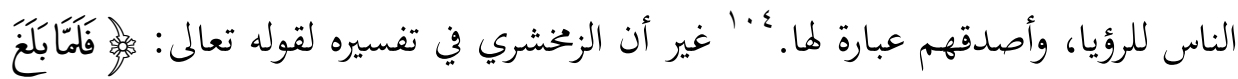

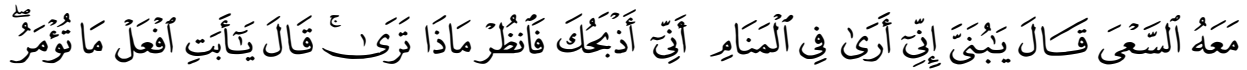

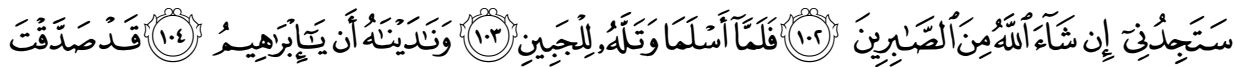

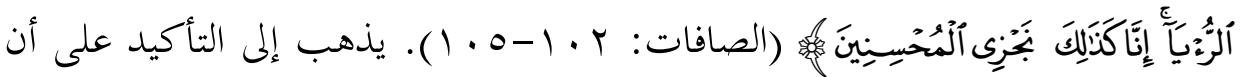

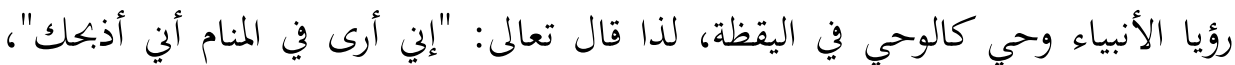
فذكر تأويل الرؤيا على أها وحي من الله تعالى.

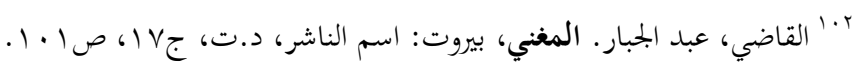

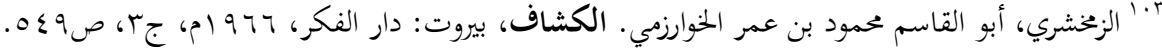

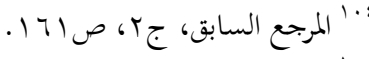

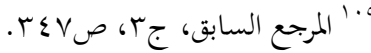


وبوجـه عـام، يـذهب جمهـور المعتزلة إلى التسـليم بـالنبوة والوحي، "ويسرون أن رؤيـا الأنبياء وحي، فالرؤيا شاهد ينهض على قيام النبوة؛ لأن الوحي الذي يهبط على الأنبياء

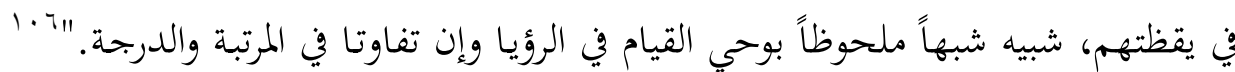

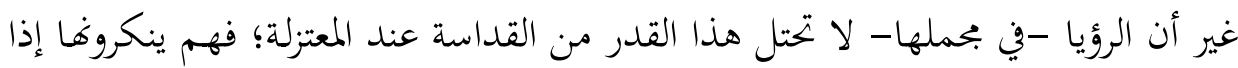

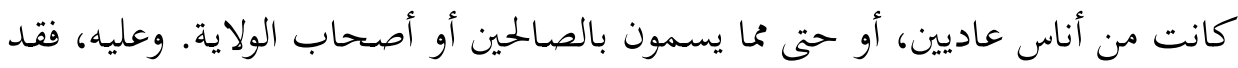
تعدّ المعتزلة -من منطلق نظرقم العقلية- الرؤيا خيالاً باطلاً كما أسلفنا.

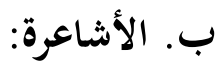

يميل بعض البـاحثين إلى القول بـأن موقف الأشـاعرة مـن الرؤيـا قريـب مـن موقف

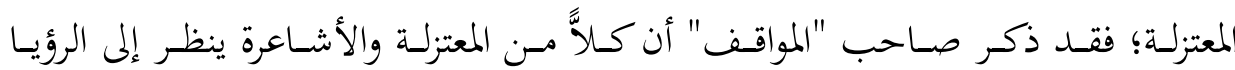

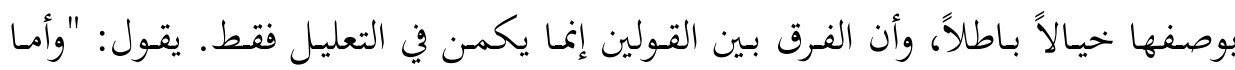
الرؤيـا فخيـال باطل عند المتكلمـين، أمـا عند المعتزلة فتفقـد شرائط الإدراك، مـن المقابلة

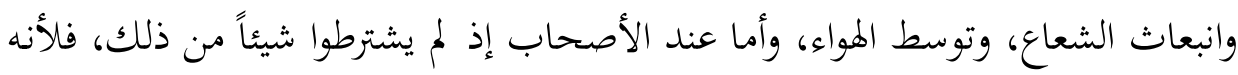

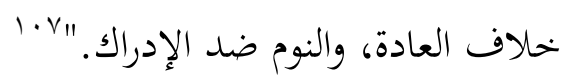

كما نسب الألوسي هذا القول إلى المتكلمين ولا سيمّا، الأشاعرة منهم. وفي ذلك

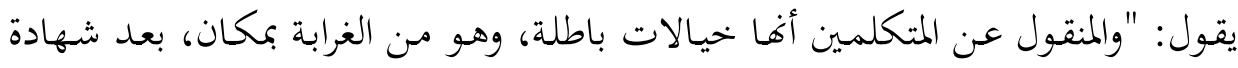

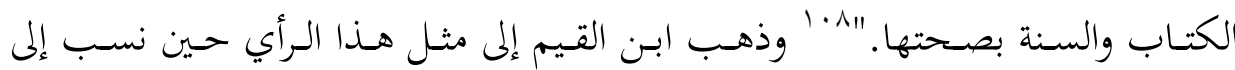
الأشاعرة القول في تعريف الرؤى بأها "علوم علقها الله في النفس ابتداء بلا سبب، إلى وهئ وهو

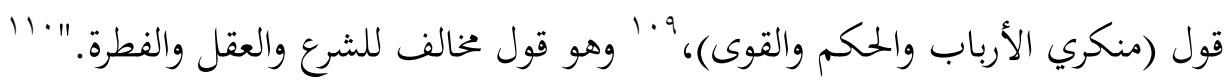

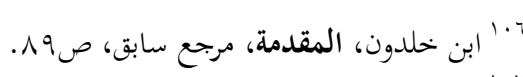

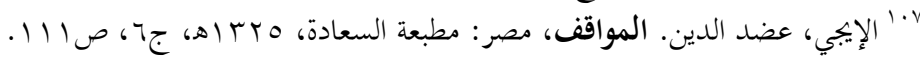

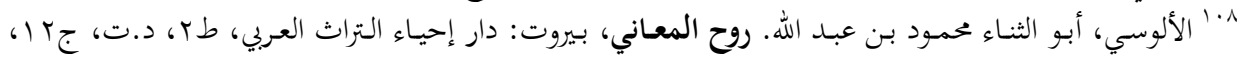
صع 11.

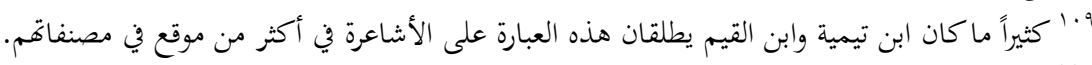

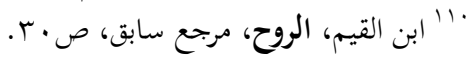




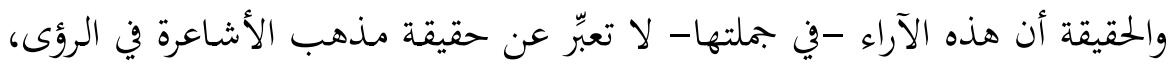

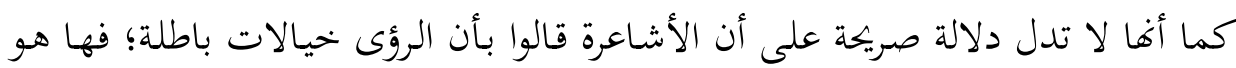
أبو بكر بن العربي -وهو مـن الأشاعرة- يقول في رده على آراء المعتزلة في إنكار الرؤيا

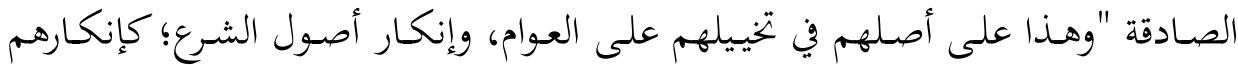

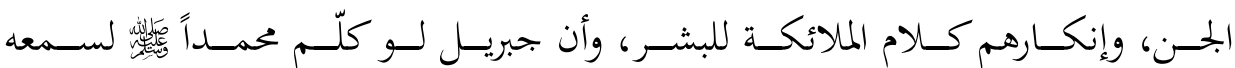

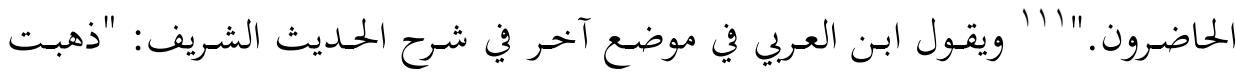

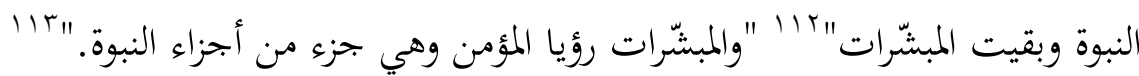
ولتفصيل آراء الأشاعرة في الرؤيا، سوف نعرض لآراء الفخر الرازي (ت ب ـ بهـ)؛

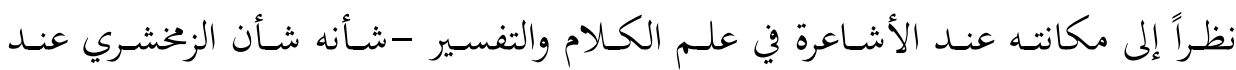

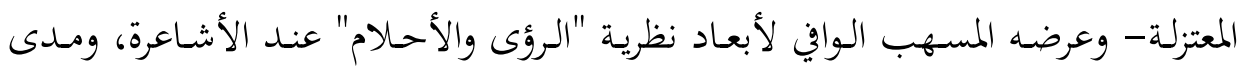

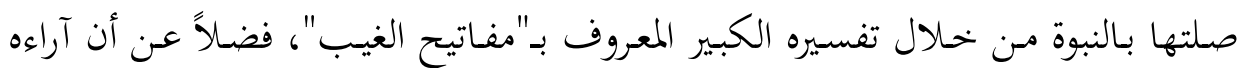

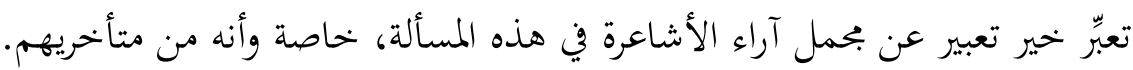

\section{- منوف الرؤى عند الرازي}

يذهب الرازي إلى أن الرؤى تنقسم إلى قسمين: منها ما هو صادق، ومنها ما هو

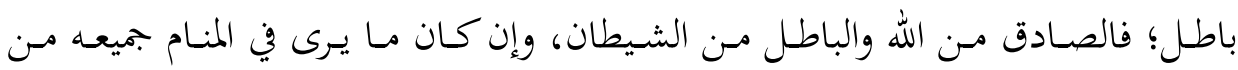

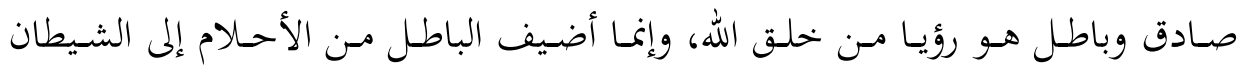

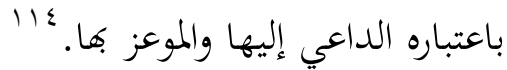

وعليه، فالشيطان يقابل الملك الذي يفيض الخير ويفيد العلم ويكشف الحق. أمّا عـن علاقة الرؤيـا بـالنبوة، فيـهـب الرازي إلى القول بـأن الرؤيـا تنبع مـن المعـين نفسه الذي تستقى منه النبوة. فتتجاوز نطاق العقل في الإدراك وتؤدي إلى السمو فوق لـون

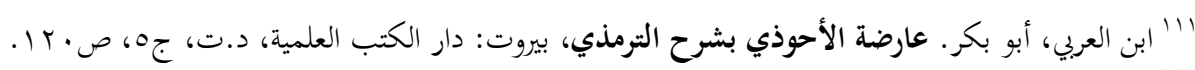

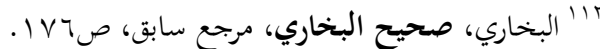

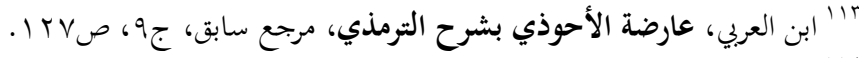

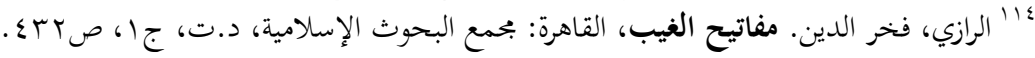

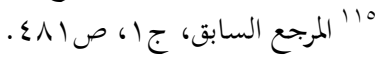


مدارك البشر، وهو ما يتوفر للأنبياء، ويتبدّى لهم من صادق الأحلام وهـم نيام. فالرؤيا هي وحي الله إبان النوم. 117

كمـا تتبـدّى الرؤيـا الصـادقة -بصـورة عامـة- في البشـر جميعـاً. وعلى ذلكـ، فرؤيـا

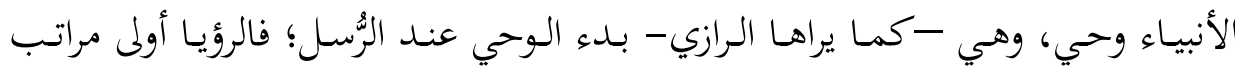

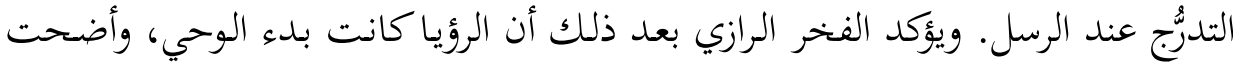

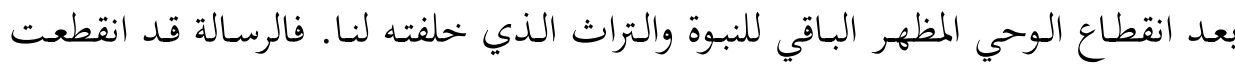

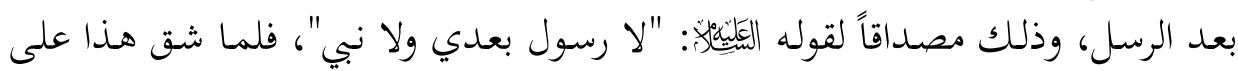

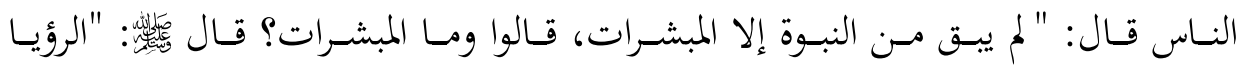

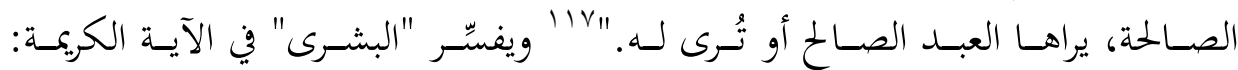

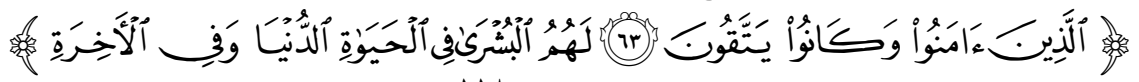

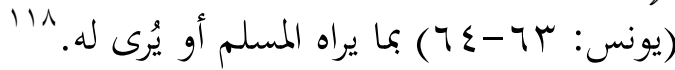

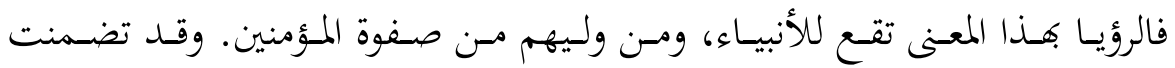

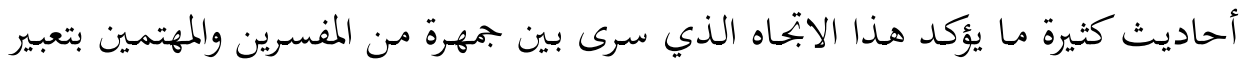
الرؤيا.

\section{رابعاً: موقف فلاسفة الإسلام من الرؤى والأحلام}

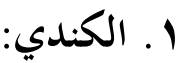

يبدأ الكندي حديثه عن حقيقة الرؤى والأحلام بالحلديث عن النوم؛ 9 إذ إذ يرى أن

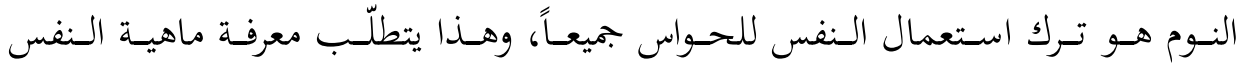

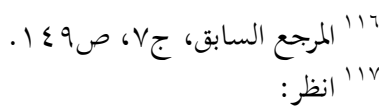

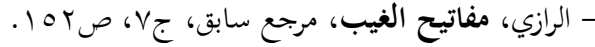

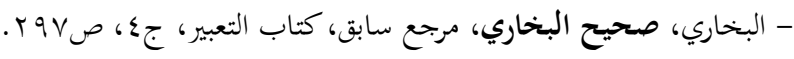

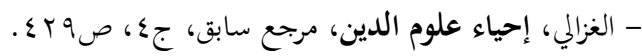

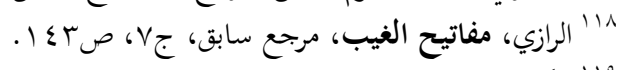

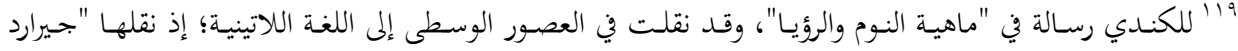

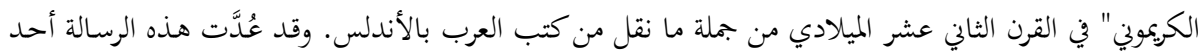

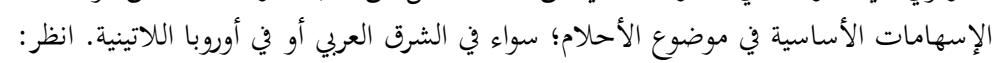




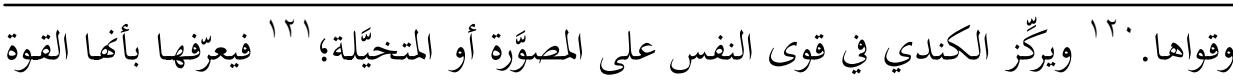

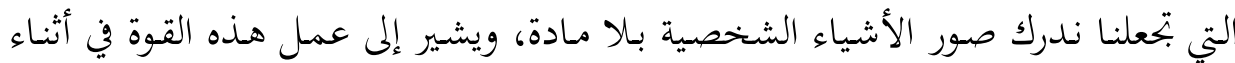

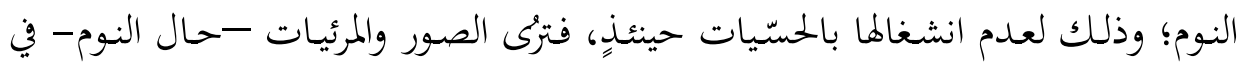
صورة رؤى وأحلام لما كانت تُرى بالحس.

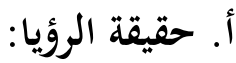

أمّا الرؤيا عند الكندي فهي: "مـا يتمثل لنـا في النوم من فكر الحسيات بحردة عن

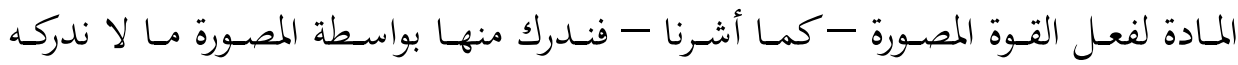

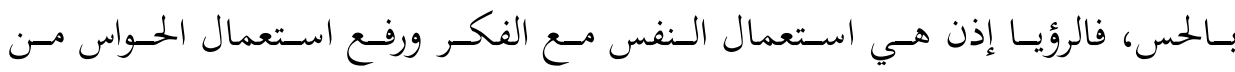

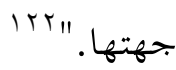

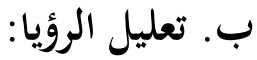

يعرض الكندي لبعض التساؤلات المتصلة بتعليل الرؤية، منها: التنبؤ بالمستقبل، أو

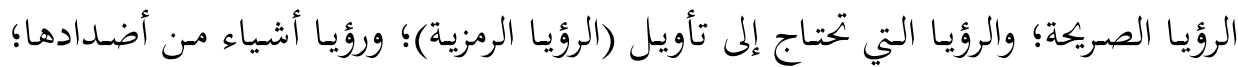
ورؤيا لا تأويل لها وهي أضغاث الأحلام.

ويبيـبـ الكنـــي عـن هـذه التســاؤلات بالإشـارة إلى أن الرؤيـا الصـادقة في التنبـؤ

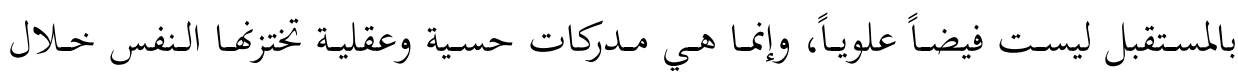

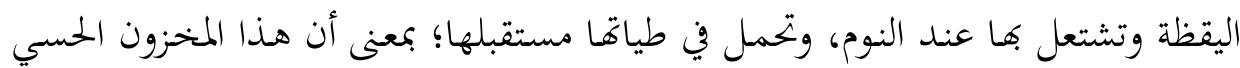

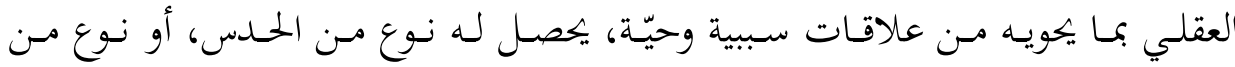

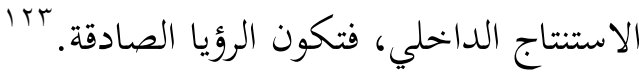

- ربيع، محمد شحاتة. التراث النفسي عند علماء المسلمين، الإسكندرية: منشأة المعارف الجامعية، ب99 (م)،

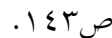

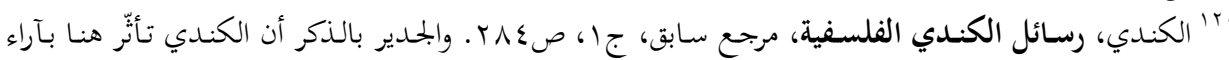

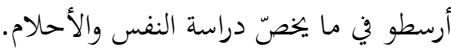

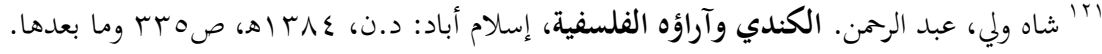

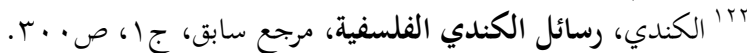

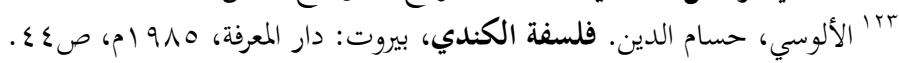


أمّا بالنسبة إلى مسألة الرمزية في الرؤيـا فيرى الكنـدي "أن الآلة (البـدن) إذاكانت أقل عهيؤاً لقبول أنباء النفس، فإن النفس -حينئذ- تحتال أو تتلطف عن طريق الرمز. فإذاذا أرادت -مثلاً- أن تُبئ شخصاً تنبئ بسفر، ولم تقو (الآلة) على أن تقبل أسباب الفكر

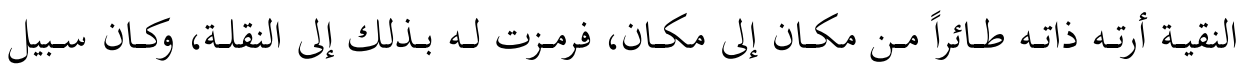

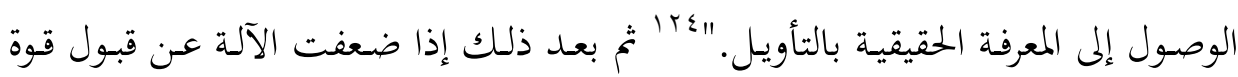

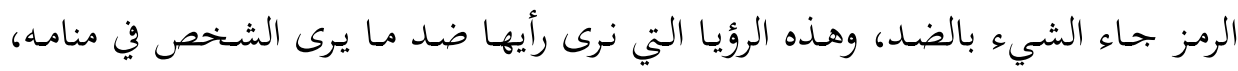

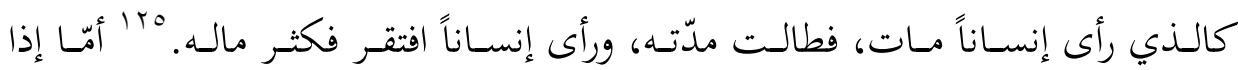
ضعفت الآلة مـا دون كل هـذه المراتب السـابقة، فبإن رؤياهـا تكـون أضغاثاً؛ أي صـوراً مختلطة لا تبـين بشيء واضـح، وكـان حـال صـاحب هــه الآلـة الرائي في المنـام، حـال المختلط بـالتفكير مشتته في اليقظة، الذي لا يستطيع أن يعبِّر عن شيء أو يركّز على ولى

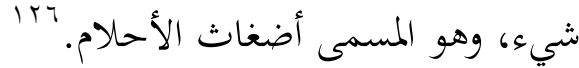

ويجمل الكندي القول في هذه الأمور؛ فيرى أن الرؤيا هي استعمال النفس والفكر وترك استعمال الحمواس، وإذا نامت الحواس رأت النفس العجائب واتصلت بالأرواح التي

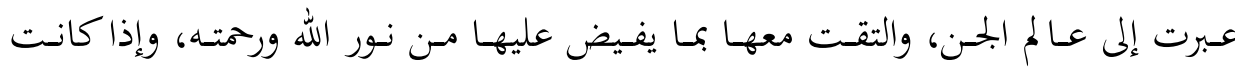
النفس صافية تامة التهيؤ لقبول آثار الأشياء وحقائقها دون أعراضها، وكانت أيضاً قادرة على التعبير عن ذلك، فإنها تستطيع في أثناء النوم أن تشاهد حقائق الأشياء مباشرة على ما هي عليه. أمّا إذا كانت أقل تهيؤاً أو مقدرةً على التعبير فإها ترمز إلى الأشياء بما يدل عليها. ويف حال ضعف تهيؤها أكثر من ذلك، فإن ما نراه يكون صوراً مختلطة وأضغاثاً لا تُنبئ بشيء واضح.

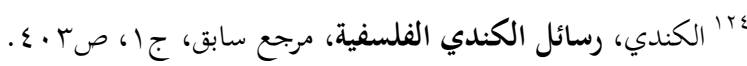

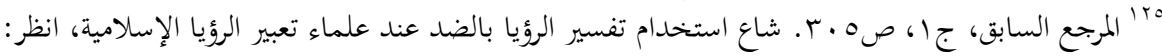

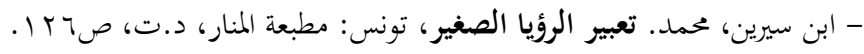

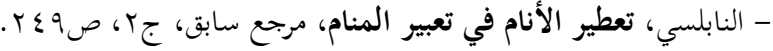

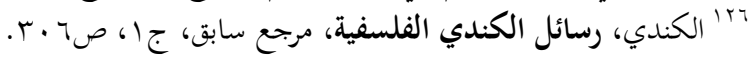




\section{ت. موقف الكندي من النبوة وعلاقتها بالؤويا:}

ينظر الكندي إلى معارف الأنبياء بوصفها أسمى وأعلى درجة من معارف الفلاسفة والصوفية؛ فهي منحة إلهية يهبها الله لمن يشاء من عباده، وهو أعلم حيث يجعل رسالته. وينتهي الكندي من ذلك إلى القول بأن مصدر الوحي والرؤيا ليس واحداً، ولذلك فهولم

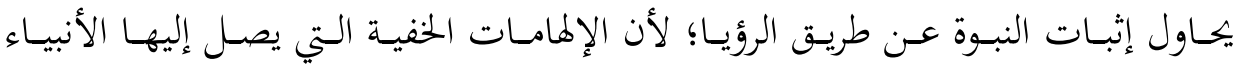

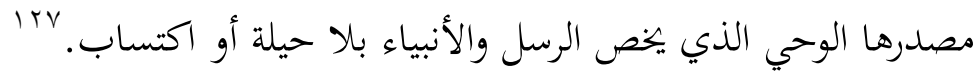

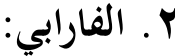

ذهب الفـارابي إلى أن الحلم يرجع إلى القوة المخحيلة أو المتخيلة كما قال اليونان؛ إذ

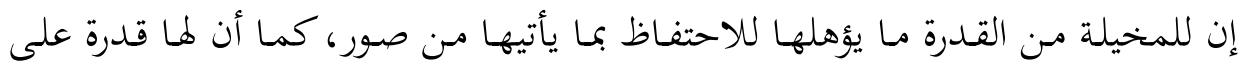
الابتكار، الذي عن طريقه يمكنها أن تؤلف عن الأفكار والصور بطريقة جديدة لمز تكن معهودة من قبل، فينتج عن ذلك الأحلام.

ويربط الفـارابي بين الرؤيـا الصـادقة والوحي؛ فالرؤيـا الصـادقة هي شعبة من شعب

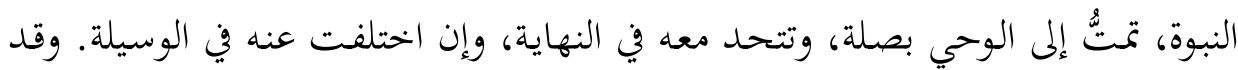

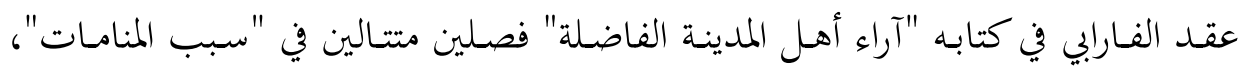

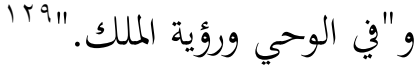

والنبوة عند الفـارابي ترتبط بقوة المخيلة؛ فالأنبياء وحـدهم هـم الذين يحوزون أعلى درجات قوة المخيلة، وهـم الذين وصلوا إلى هذه المرتبة العليا دون غيرهم مـن البشر؛ إذ وركي

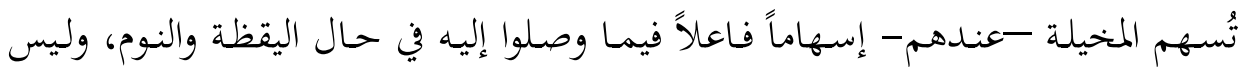

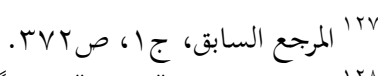

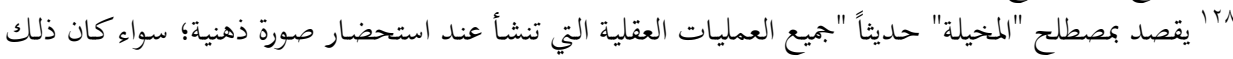

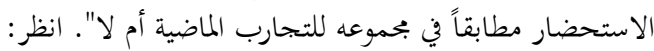

- Runeo , Dictionary of philosophy, New York, 1942, P 216.

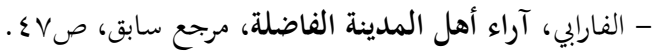

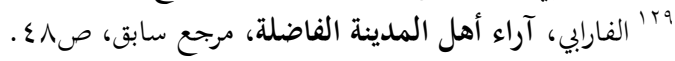




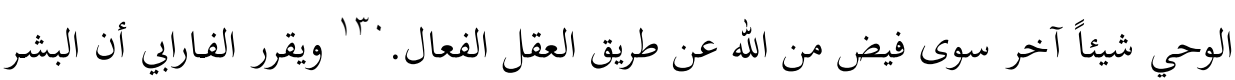

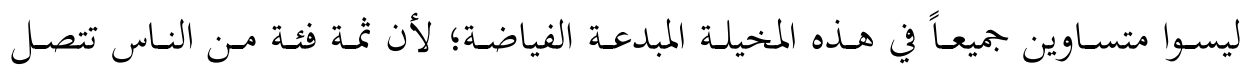
بالعقل الفعال بوساطة المخيلة في النوم فقط، ومن هذا القبيل الأولياء. ويحصر الفارابي بعد ذلك حقيقة النبوة في قوى ثلاث؛ الأولى: قوة التأثير: وهي أن

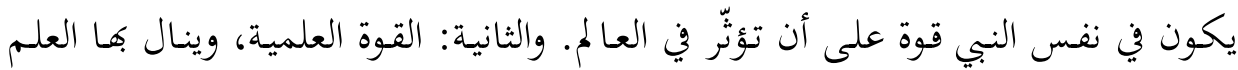

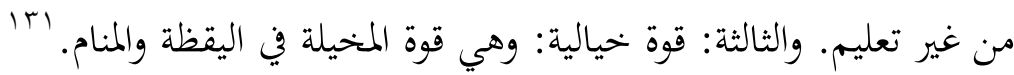
غير أن المدقِّق - عمومـاً - في كـام الفـارابي عن الوحي والنبوة، وتفسيره لها مـن الناحية العقلية والنفسية، يجـده لا يتفق مع النصوص الدينية الثابتة؛ فقـد ورد أن جبريل

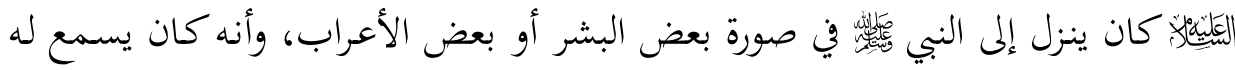
صلصلة مثل صلصلة الجحس إلى غير ذلك.

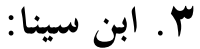

ضمَّن ابن سينا معظم آرائه عن الأحلام والنوم في مؤلفات عديدة، أبرزها الفصل

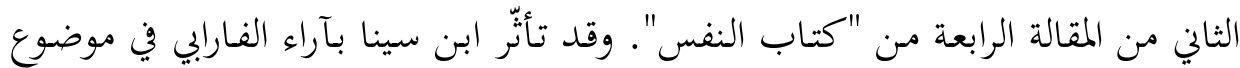

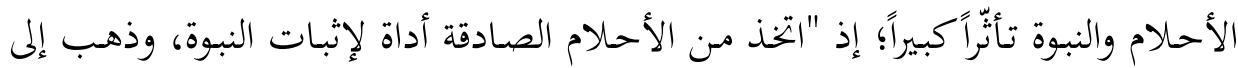
القـول بـأن الأحـداث؛ ماضـيها وحاضـرها ومستقبلها منقوشـة في لوح محفوظ في العـا لم العلوي، وفي وسع بعض الناس الاتصال بهذا العالم عن طريق مخيلتهم القوية، فيقع لهم

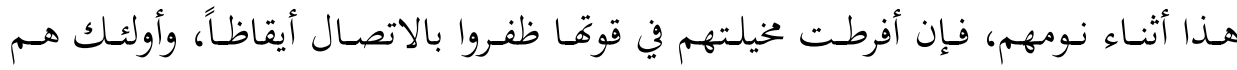

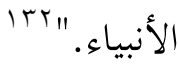

وفيما يخصّ علاقة الرؤية الصادقة بالنبوة، حرّر ابن سينا رسالة مستقلة عن "إثبات

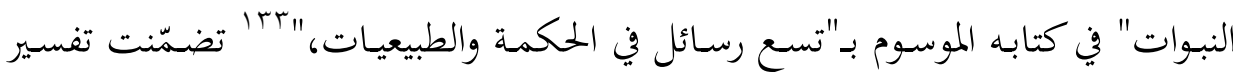

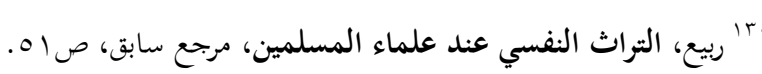

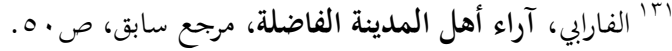

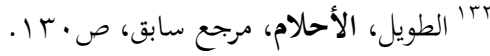

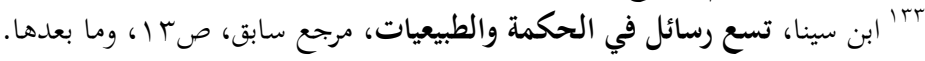




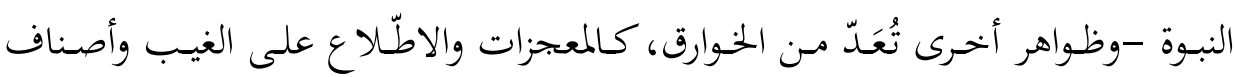

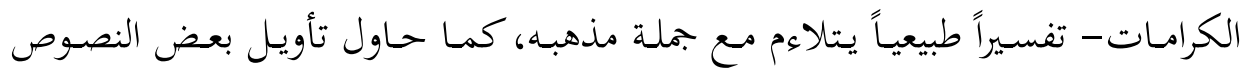

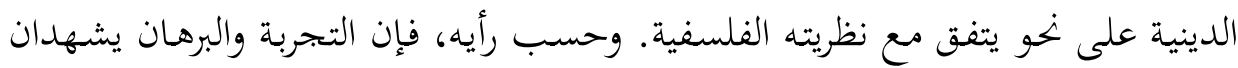

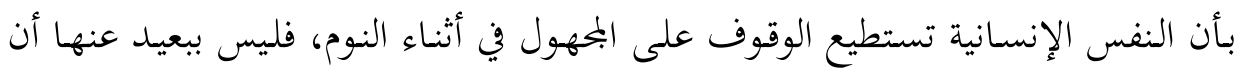

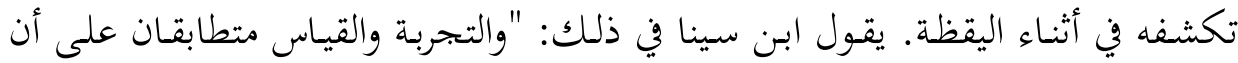

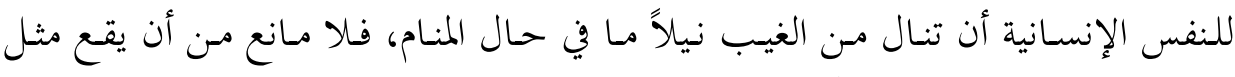

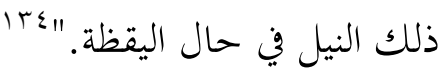

وتفسير ذلك -عند ابن سينا- أن هناك نوعاً مـن الأحلام لا ينشأ عن أحاسيس

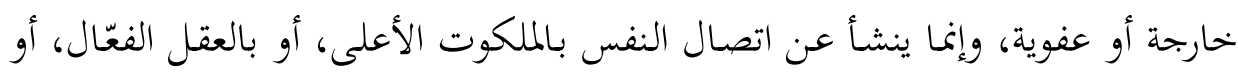

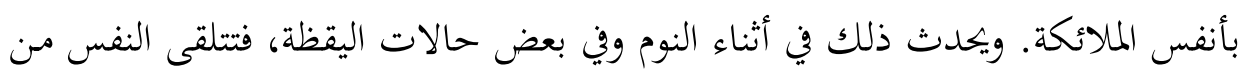

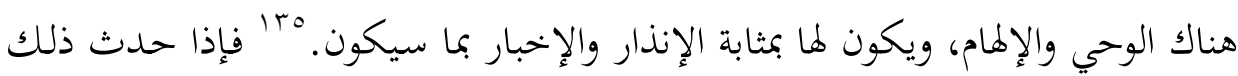

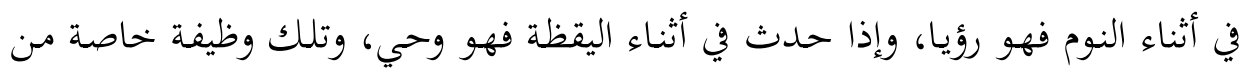

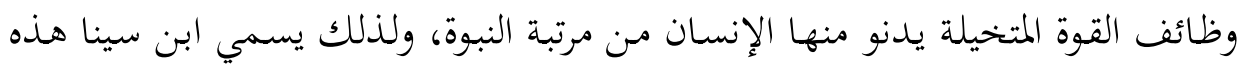

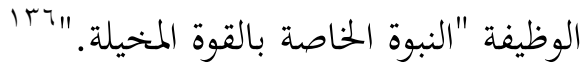

\section{ع. ابن رشد:}

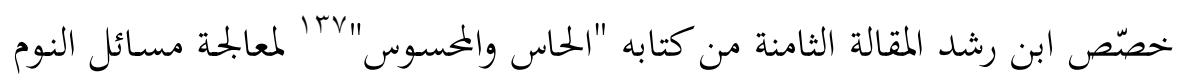

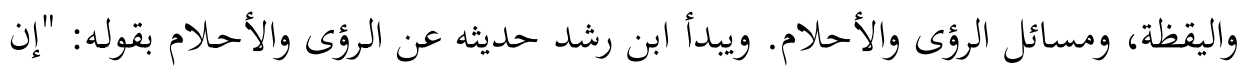

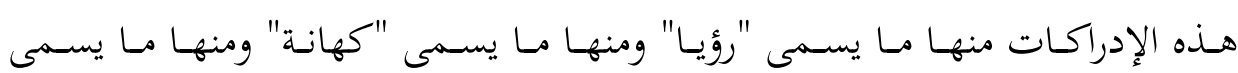

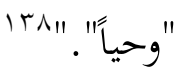

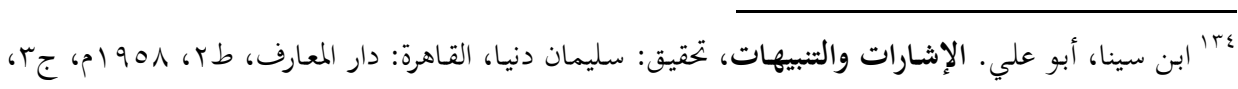
ص إl مبر

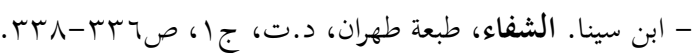

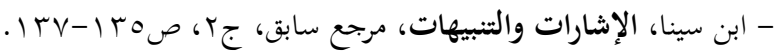

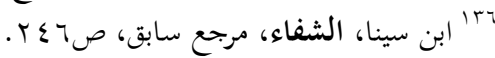

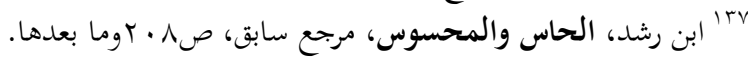

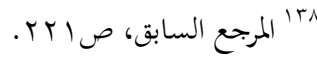


وتنقسم الرؤيا عند ابن رشـد إلى قسمين: صادقة وكاذبة، وهي في الحالتين تنتسبب

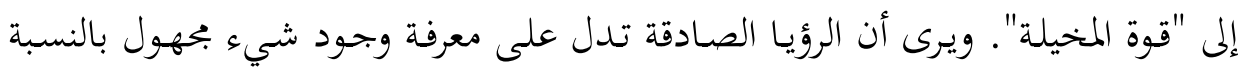

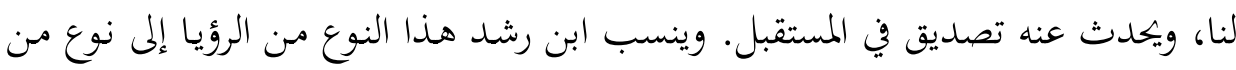

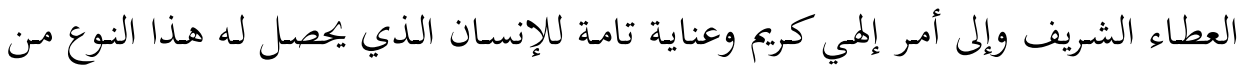

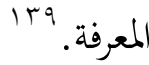

ويرى ابن رشد أن الرؤيا الصادقة هي جزء من النبوة، وأها من الأمور التي تصيب

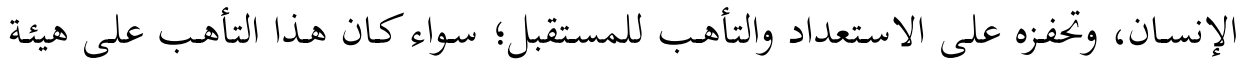

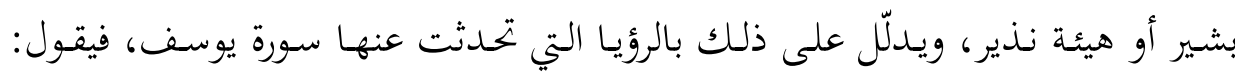

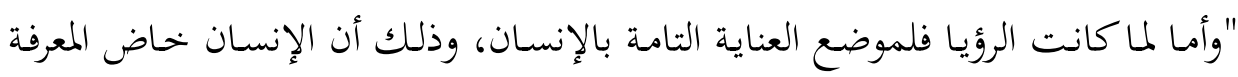

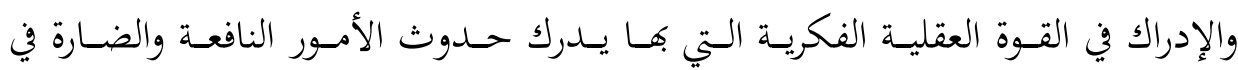

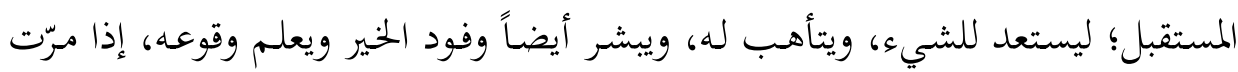

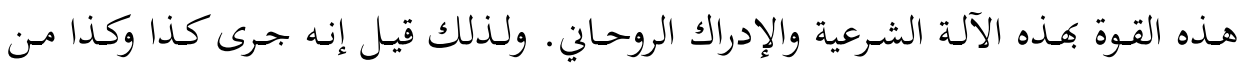

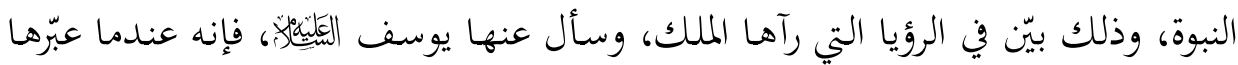

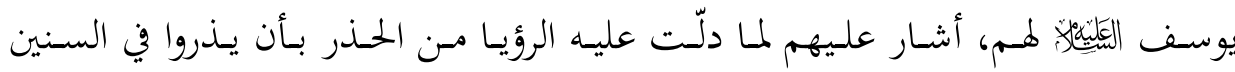

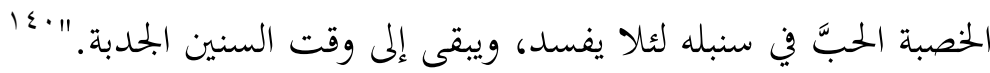

أمّا فيما يخصّ الرؤيا الكاذبة فيرى ابن رشد أفها تحدث بسبب المتشوقات الطبيعية

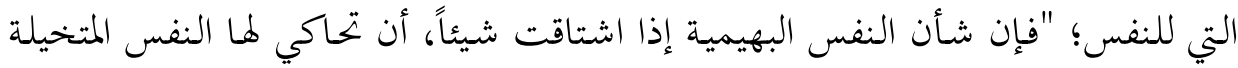

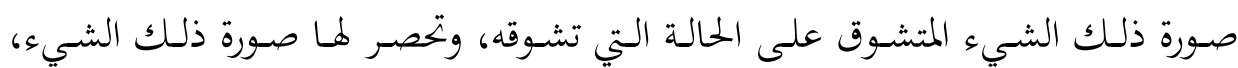

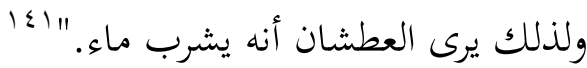

\section{خامساً: موقف الصوفية من الؤى والأحلام}

تأثّر متصوفة الإسلام في كلامهم عن الرؤى والأحلام بروافد خارجية، أهمها مذهب

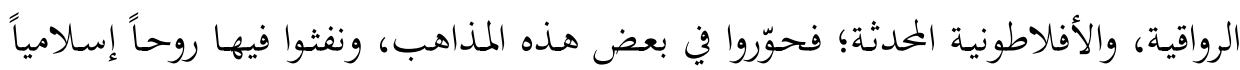

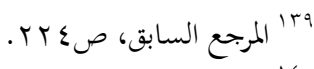

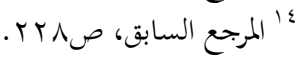

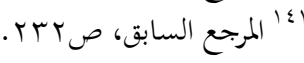


صرفاً، كاد يفقدها ملامعها الأولى، ويقطع اتصالها بأصلها. وقد قدّم المتصوفة - في هذا

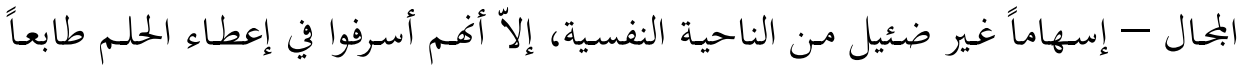

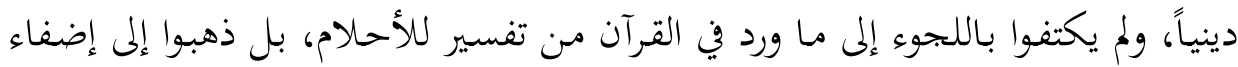

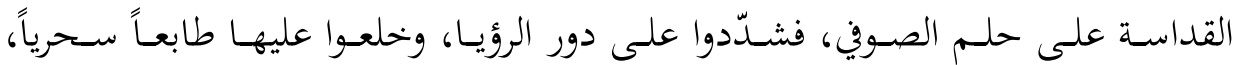
وسخّروها في خدمة القيم الصوفية. وفي محاولتهم تقريب الصوفي (الولي) من النبي، ألصقوا الرؤيا بالنبوة وجعلوها صنواً لها.

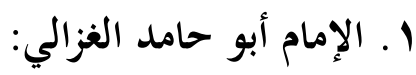

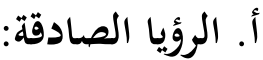

يذذهب الغزالي إلى القول بـأن الطاقة التي يطل منهـا المرءع على عـالم الملكـوت، قد تنفتح إبّان النوم في رؤيا صادقة، وقد تنفتح في أثناء اليقظة لمن أخلص الجهاد والرياضة،

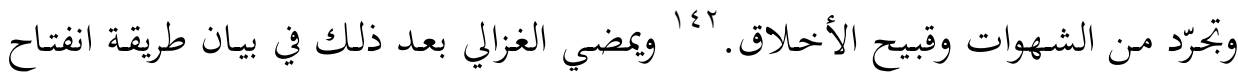
الرؤيا لدى الصوفي، فيقول إن ذلك يكون "باعتزال الناس وتعطيل طرق الحواس (المعرفة الحسية) وفتح عين الباطن وسمعه، عندئذ تنمحي الظلمة بحروفها، ويبقى معناها بحرداً في قلبه، ويتعرض لنفحات رحمة الله، وتنفتح الطاقة، ويبصر في اليقظة مـا يبصره في النوم،

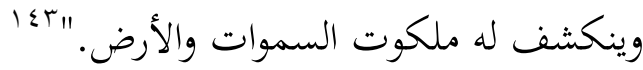

ويرى الغزالي أن الوحي لا يختلف عن الإهام بطريق الرؤيا، لأن كالًّ منهما ينبع من

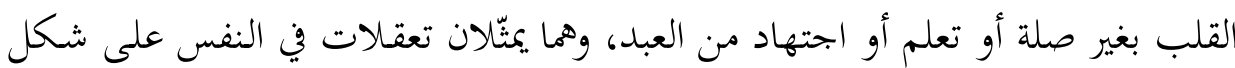

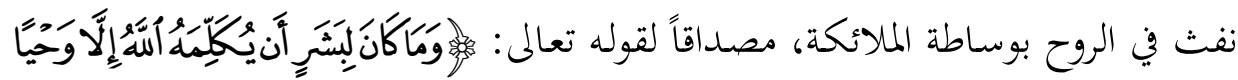

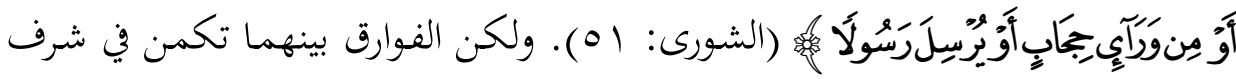

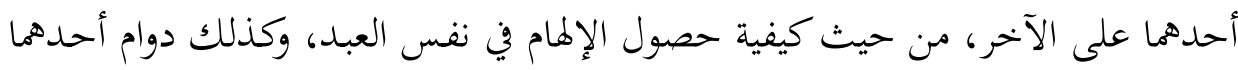
(الإلمام) دون الآخر (الوحي). ويطلق على العلم الذي يكصل بطريق الوحي اسم العلم

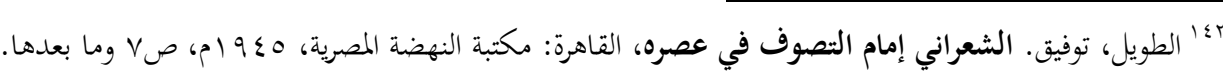

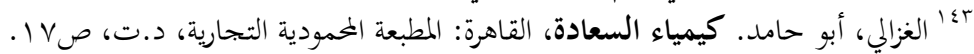


الكلي، وهو من أشرف العلوم لكونه يصدر عن العقل الكلي، وهو أشرف من النفس

\section{ب. تعبير الرؤيا عند الغزالي:}

كـرّر الغـرالي جملـة التفسـيرات السـيرينية المتعلقــة بموضـوع "تعبـير الرؤيـا"، بـل وردّد

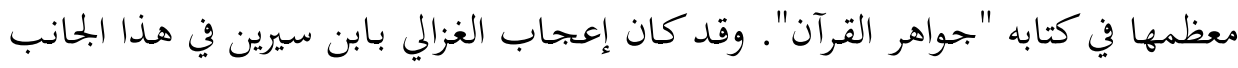

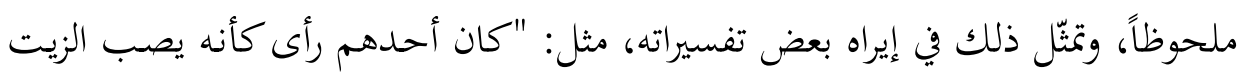

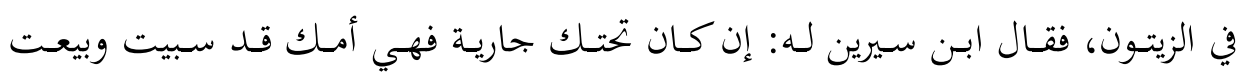

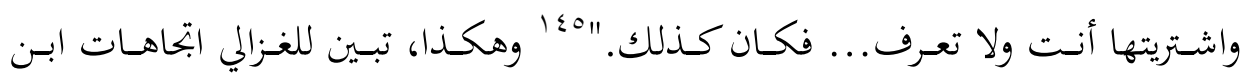

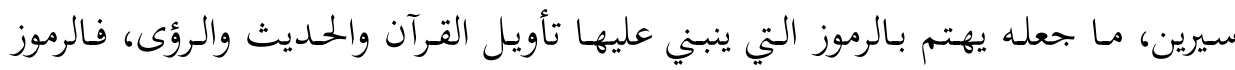

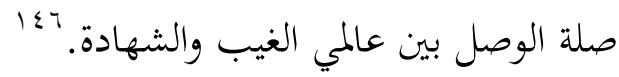

ثمـة مـن يـرى أن الغزالي قـد تأثّر بفلاسفة اليونـان، فقـد ذهـب كلّ مـن: مارجريـت

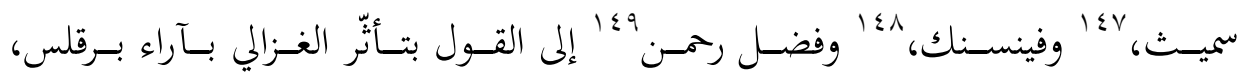

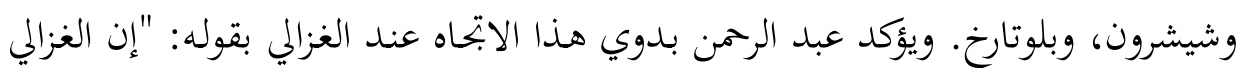

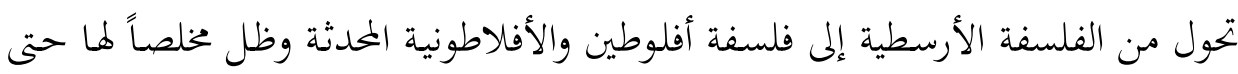
آخر عمره.

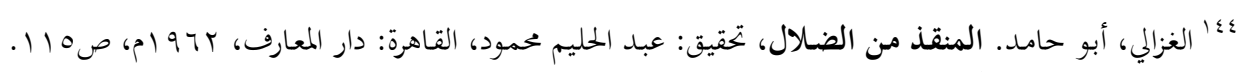

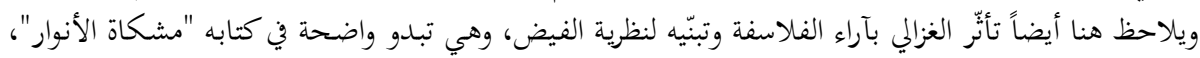

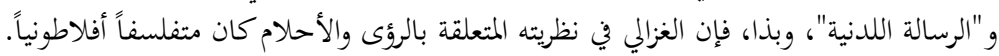

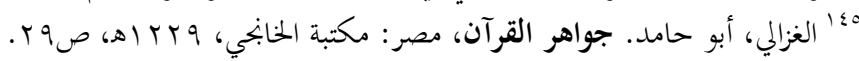
147 Smith (M): ALGhazali (the mytic, London 1944 p.p 105-114.

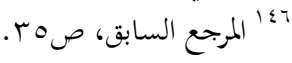
148 Wensinke (A.J): la pensee de AL Ghazali 1940 p.p61-62.

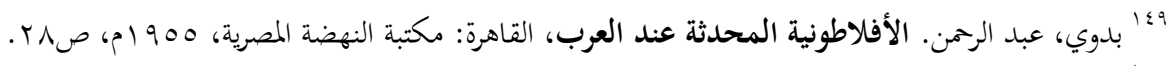

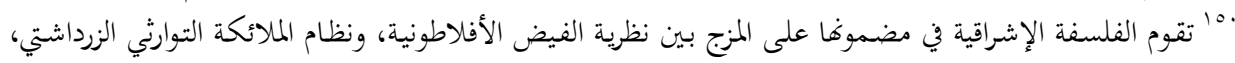

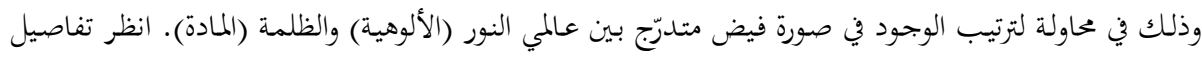

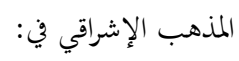

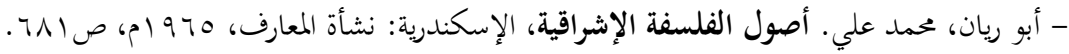

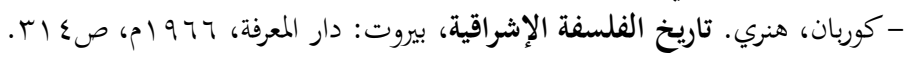




\section{r. بوقف التصوف الإشراقي 101 من الؤيا (شهاب الدين السهروردي):}

يذهب السهروردي -في تفسيره مسألة الرؤيا- إلى تقرير إمكان اتصال أرواحنـا في

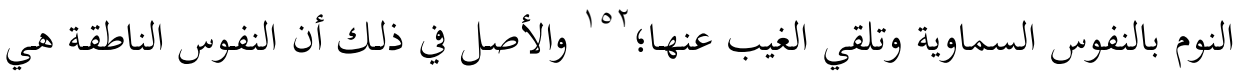

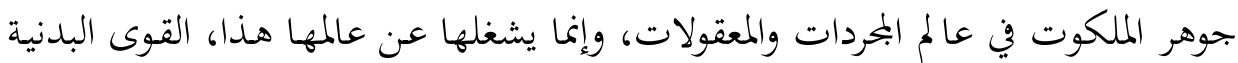

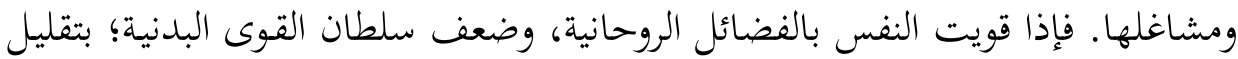

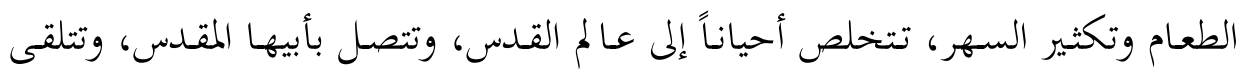

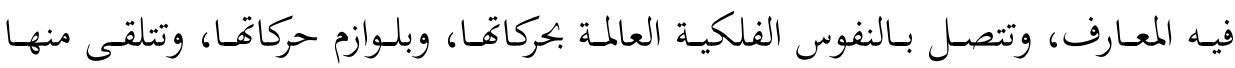
المغيبات في نومها ويقظتها كمرآة تنتقش بمقابلة ذي نفس. وعليه، فإذا تطهرنا من شواغل البدن وتأملنا كبرياء الحقق والنور الفائض من لدنه،

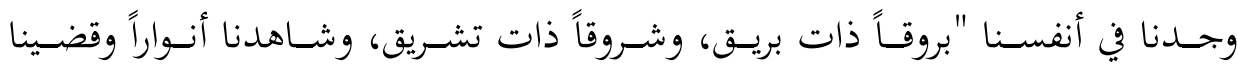

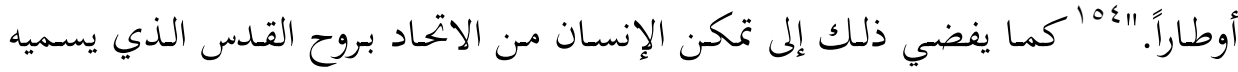

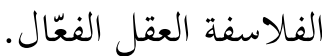

\section{r. موقف أصحاب وحدة الوجود من الؤيا (محي الدين بن عربي):}

يذهب أصحاب وحدة الوجود -الذين يمثّلون مذهباً فلسفياً صوفياً- إلى تأكيد أن

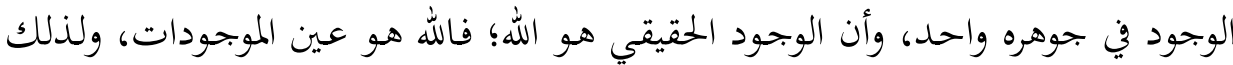

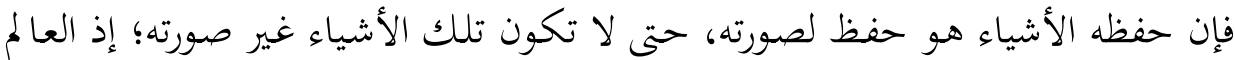

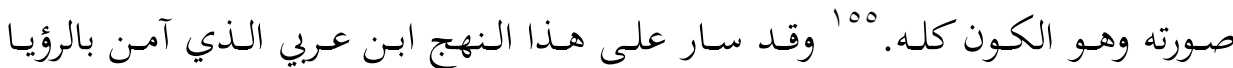
الصادقة إيماناً راسخاً، وعدّها من المبشرات.

10أبو ريان، أصول الفلسفة الإشراقية، مرجع سابق، ص97 . وإلى مثل هذا القول يذهب الغزالي وإخوان الصفا أيضاً.

rol السهروردي، يهيى بن حبش (المقتول). هياكل النور، تمقيق محمد علي أبو ريان، القـاهرة: مطبعة السعادة، 每

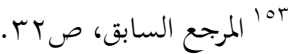

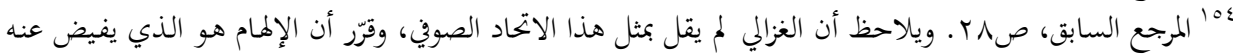
العلم الذي يصدر عن الله من غير واسطة.

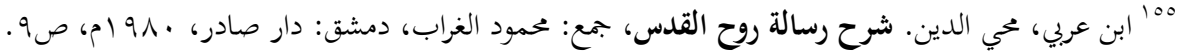

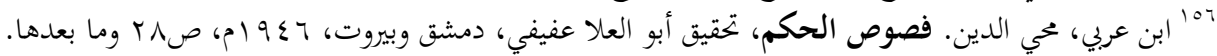




\section{أ. الؤيا والكشف الصوفي في مذهب وحدة الوجود:}

يذهب ابن عربي إلى تقسيم الكشف الصوفي إلى صوري ومعنوي؛ "والأول يقع في

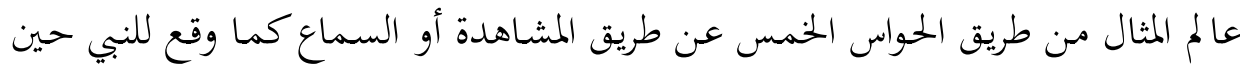

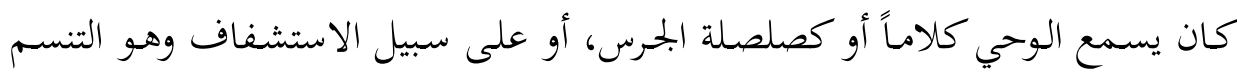

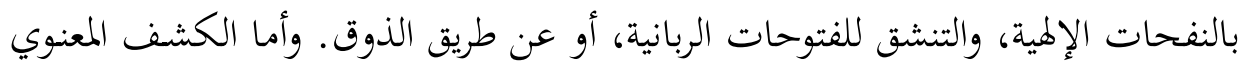

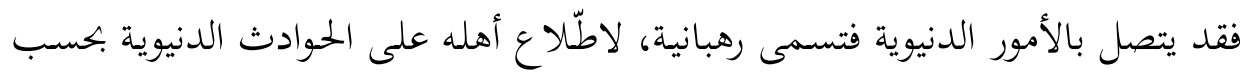

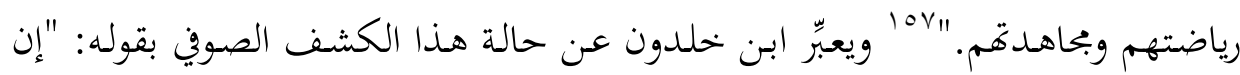

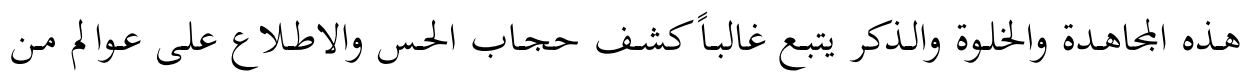

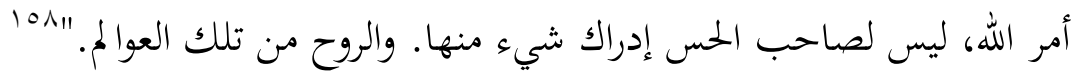

وهذا الاطلاع على هذه العوالم، وهذا الإدراك الرباني عند ابن عربي، يأتي من طرائق

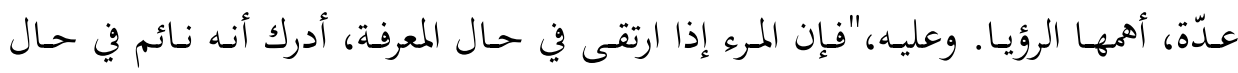

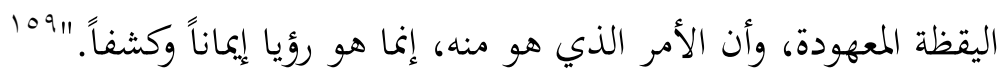

\section{ب. صلة الرؤيا بالولاية:}

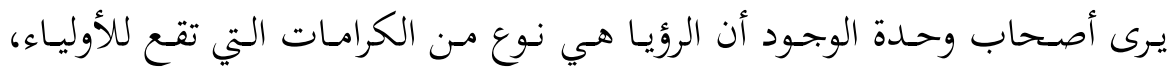

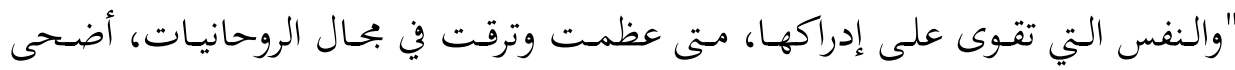

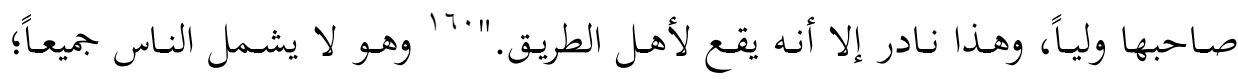

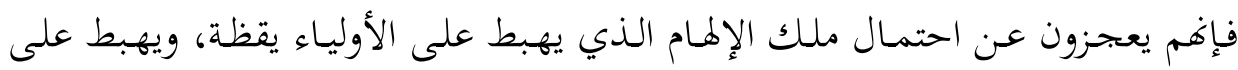

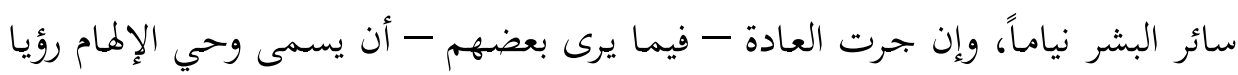

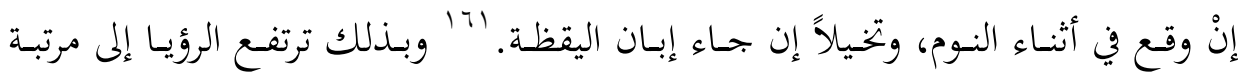

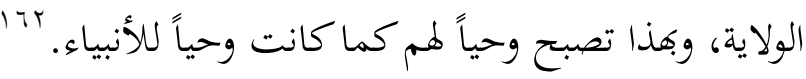

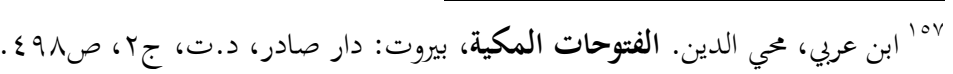

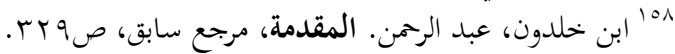

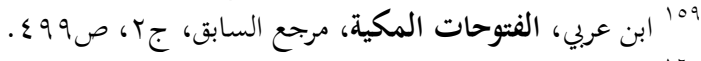

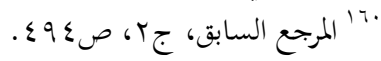

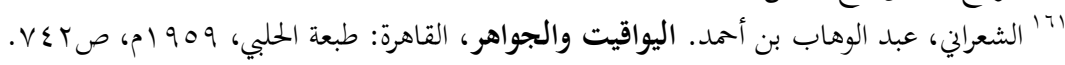

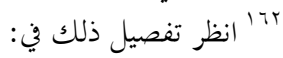




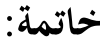

نخلص محا سبق إلى أنَّ موضوع الرؤى والأحلام وصلتها بالنبوة، هو من الموضوعات

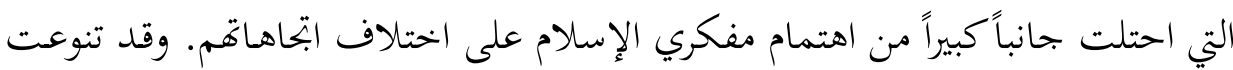

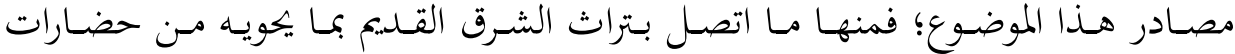
وديانات مختلفة، ومنها ما اتصل بتراث اليونان والرومان الذي تميّز بالنظر العقلي، وربط

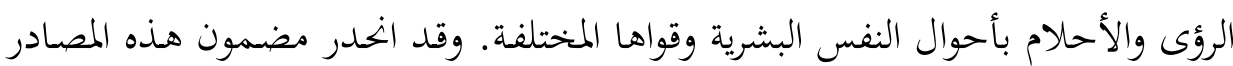

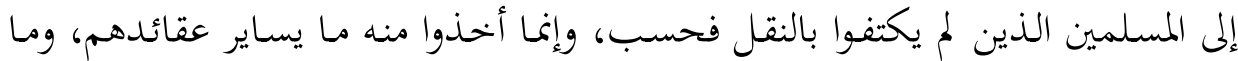
يتناغم مع طبيعة تفكيرهم، وانصرفوا عمّا يخالف تعاليم دينهم الحنيف. وقـد تباينـت ردود أفعـال المسـلمين بجـاه مـا ورد مـن هـذه المصـادر التراثيـة في الرؤى

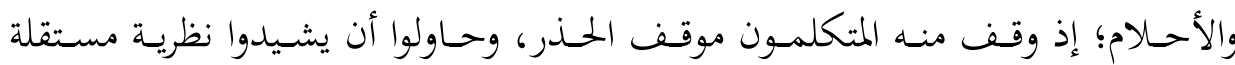
مستمدة من القرآن الكريم والسنة النبوية، تقوم في أساسها على اتخاذ الرؤيا الصادقة دليلاً يؤكد صدق النبوة. أمّا فلاسفة الإسلام فقد انتفعوا (في بحث الرؤيا عقلياً) بتراث اليونان والرومان، ولا سيّما كتابات أرسطو، إلاّ أهمم أضافوا إليه أدلة من إبداع تفكيرهم ووحي

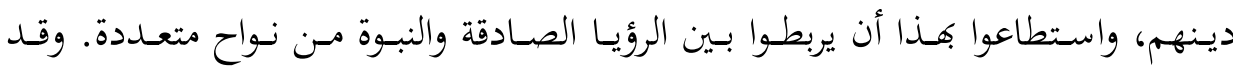
جاراهم المتصوفة في هـا الأمر؛ فنهلوا مـن مـذهبي الرواقية والأفلاطونية المحدثة ونوهما، وإن كانوا قـد حوّروا في بعض هـذه المذاهب، وبثّوا فيها روحـاً إسـلامية كـادت تفقـدها ملامحها الأولى، وتقطع اتصالها بأصلها. وقد ظهر ذلك واضحاً جلياً - كما مرّ بنا - في مذاهب التصوف السني والإشراقي، واعتقاد أصحاب نظرية وحدة الوجود. إن ثمة حاجة ماسة إلى استثمار ما دار في الفكر الإسلامي من محاورات حول هذه القضية؛ إذ إن ما يُعرض في الفضائيات من برامج تعالج موضوع الأحلام وما يتصل بهـا مـن محاولة تشكيل الشخصية، ضمن مخطط قد يبدو ممنهجاً لتجهيل النشء، ومحاولة 
تشويه التراث الإسـامي في التعامل مع قضـايا تفسير الأحلام، يفرض على المؤسسـات البحثية والأكاديمية القيام بمهمة تصحيح الرؤى وكشف زيف كهنة الفضائيات وعرّافيها، الذين يتكئون زوراً على أحاديث العلماء، وقطع أفكارهم وعباراهم عن سياقاتا الزمانية والمكانية والموضوعية. كما أن ثمة حاجة للتأسيس العلمي لبحث علاقة الرؤى بالنبوات، واستقراء الدراسـات الثقافيـة والفكرية التي تصدـت لهذا الموضوع، ومحاولة تصنيف هـذه الدراسات، و إبراز مكانتها في التفكير الإسلامي. 